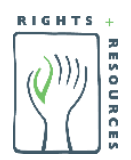

\title{
Mai-Ndombe: Will the REDD+ laboratory benefit Indigenous Peoples and local communities?
}

Analysis of the cumulative impacts and risks of REDD+ initiatives

\section{Rights and Resources Initiative}

2715 M Street NW, Suite 300

Washington, DC 20007

P : +1 202.470.3900 | F : +1 202.944.3315

www.rightsandresources.org 
RRI is a global coalition consisting of 15 Partners, 7 Affiliated Networks, 14 International Fellows, and more than 150 collaborating international, regional, and community organizations dedicated to advancing the forestland and resource rights of Indigenous Peoples and local communities. RRI leverages the capacity and expertise of coalition members to promote secure local land and resource rights and catalyze progressive policy and market reforms.

RRI is coordinated by the Rights and Resources Group, a non-profit organization based in Washington, DC. For more information, please visit www.rightsandresources.org.

Partners
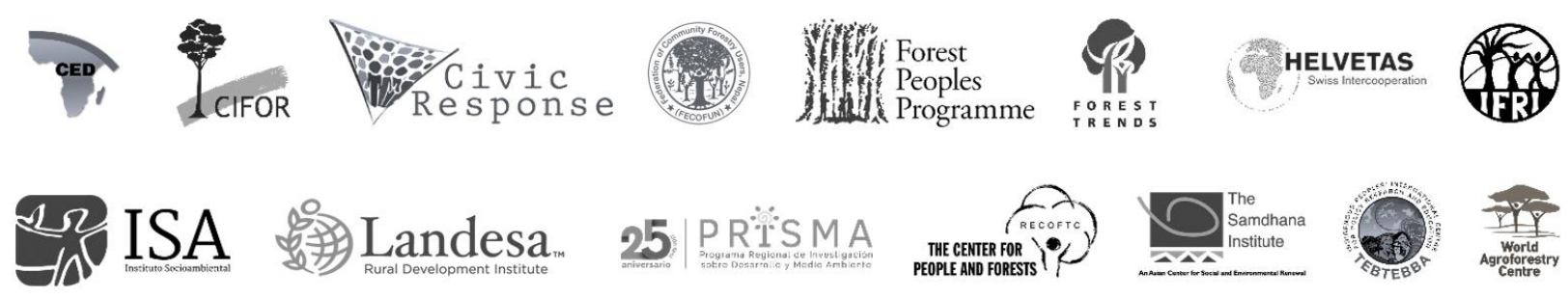

\section{Affiliated Networks}
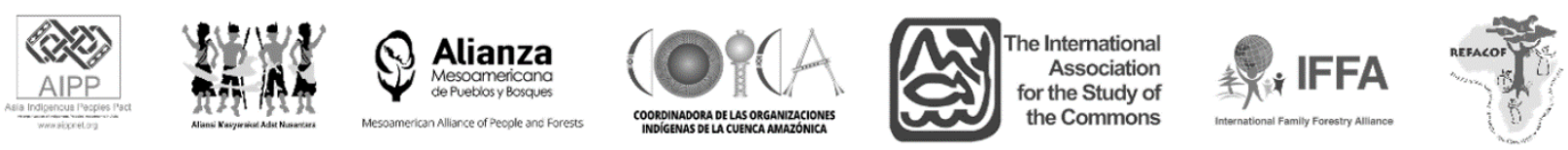

\section{Sponsors}

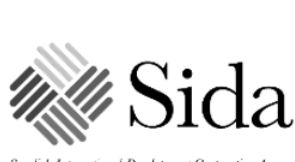
C. Schweizerische Eidgenossenschal
Confécération suisse
Confeceraziun svizra
Swiss Agency for Development
and Cooperation SDC
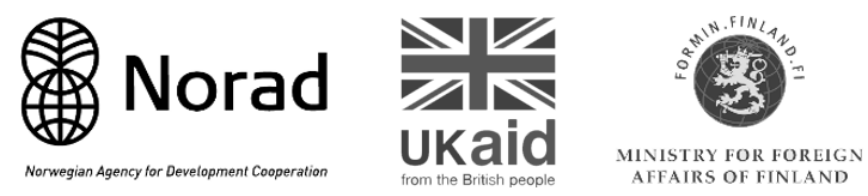

\section{8\% FORDFOUNDATION}

The views presented here are not necessarily shared by the agencies that have generously supported this work, or all of the Partners and Affiliated Networks of the RRI Coalition. This work is licensed under a Creative Commons Attribution License CC BY 4.0. 


\section{Contents}

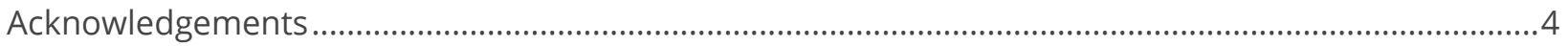

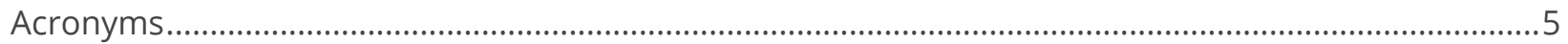

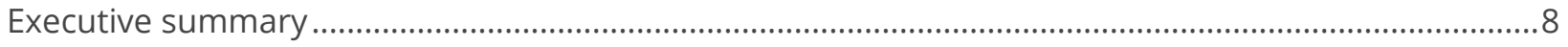

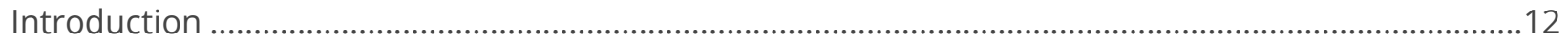

1. Mai-Ndombe Province: A REDD+ Laboratory in the Democratic Republic of the Congo ..................14

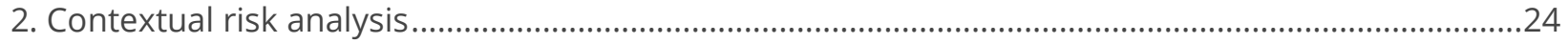

2.1 Governance: A major challenge for a new province in a post-conflict country ...........................24

2.2 Land conflicts: Between land duality and pressures on the land .................................................26

2.3 Carbon rights, land rights, and securing community rights: A complex and little-known legal

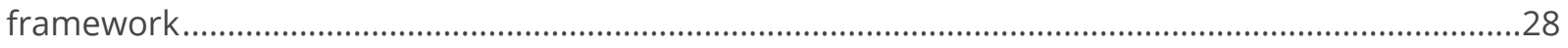

2.4 The rights of Pygmy Indigenous Peoples: Recognized but flouted ................................................33

2.5 Strong discrimination against rural and indigenous women ..........................................................33

2.6 Difficult living conditions and low livelihoods of communities ......................................................36

2.7 Limited community participation in decision-making processes..................................................37

3. Are the cumulative impacts of REDD+ initiatives under control? ........................................................39

3.1 Governance: A fragile and incomplete architecture ....................................................................39

3.2 Conflict mitigation: undervaluation and threat to REDD+ outcomes ............................................42

3.3 REDD+ activities' structure: lack of environmental and community anchoring ...........................45

3.4 Right to land: isolation of the problem and not taking into account land dynamics ...................51

3.5 Rights of Indigenous Peoples: A compensation strategy without secure rights ...........................53

3.6 Gender: Women are still at the margins of REDD+ projects ..........................................................54

3.7 REDD+ benefit sharing: risks compromising REDD+ objectives ......................................................56

3.8 Improvement of living conditions: poorly-targeted beneficiaries and poorly-controlled impacts

3.9 Stakeholder participation and accountability: low community ownership ...................................58

4. Conclusion and priorities for action - mitigating the risks of implementing REDD+ in Mai-Ndombe

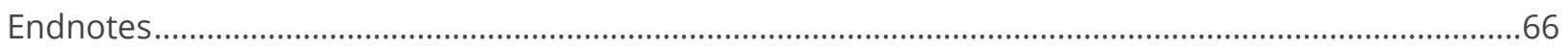




\section{Acknowledgements}

This report was written by Marine Gauthier and translated into English by Stephanie Guico. Maps were created by Riccardo Pravettoni.

The author wishes to express her heartfelt appreciation for the comments made by the experts committee who has devoted time and energy to the revision of this report and whose significant and constructive contributions helped improve it: Lien De Brouckere (RRI), Alain Frechette (RRI), Stephanie Keene (RRI), Théophile Gata (CAGDFT), Chouchouna Losale (CFLEDD), Alain Ngulungu (FPP), Serge Bontolo (OGF), Joe Eisen (RFUK), Simon Counsell (RFUK), Blaise Mudodosi (RRN), Camille Reyniers (Free University of Brussels), Augustin Mpoyi (CODELT), and Adeline Dontenville (EFI).

She also thanks all REDD+ actors, technical and financial partners, project leaders, as well as international and national civil society representatives, for the time devoted to answering questions and providing the information and documents that made this analysis possible. The following institutions provided data and information: World Bank, CERN - Inongo, DGPA, FIP, FONAREDD, GTCR - R, LICOCO, Moabi, Rainforest Foundation Norway, WWF, REPALEF. 


\begin{tabular}{|c|c|}
\hline AFD & French Development Agency \\
\hline ADB & African Development Bank \\
\hline CACO & Cadre de concertation des organisations de la société civile pour la réforme foncière \\
\hline CADEM & Centre d'accompagnement de la population pour le développement de Mai-Ndombe \\
\hline CAFI & Central Africa Forest Initiative \\
\hline CARG & Conseil agricole rural de gestion \\
\hline CARPE & Central Africa Regional Program for the Environment \\
\hline ERPA & Emission Reduction Payment Agreement \\
\hline CEDAW & Convention on the Elimination of All Forms of Discrimination Against Women \\
\hline CERN & Commission épiscopale pour les ressources naturelles \\
\hline CESCR & Committee on Economic, Social and Cultural Rights \\
\hline CFCL & Concessions des forêts des communautés locales \\
\hline CFLEDD & Coalition of Women Leaders for the Environment and Sustainable Development \\
\hline $\mathrm{Cl}$ & Conservation International \\
\hline CL & Communautés locales \\
\hline CLD & Comités locaux de développement \\
\hline FPIC & Free, prior, and informed consent (Consentement libre, informé et préalable) \\
\hline CN-REDD & Coordination nationale REDD \\
\hline UNCAC & United Nations Convention Against Corruption \\
\hline CODELT & Conseil pour la défense environnementale par la légalité et la traçabilité \\
\hline CONAPAC & $\begin{array}{l}\text { National Confederation of Agricultural Producers of Congo (Confédération nationale des } \\
\text { producteurs agricoles du Congo) }\end{array}$ \\
\hline CONAREF & National land reform coordination (Coordination nationale de la réforme foncière) \\
\hline DIAF & $\begin{array}{l}\text { Forest Inventories and Management Branch (Direction des inventaires et aménagement } \\
\text { forestiers) }\end{array}$ \\
\hline DIM & Direct Implementation Modality \\
\hline EFI & European Forest Institute \\
\hline (RIL) & Reduced impact logging \\
\hline ERA & Ecosystem Restoration Associates \\
\hline ERPIN & Emission Reduction Program Idea Note \\
\hline FAO & Food and Agriculture Organization \\
\hline FCPF & Forest Carbon Partnership Facility \\
\hline FONAREDD & National REDD Fund (Fonds national REDD) \\
\hline
\end{tabular}




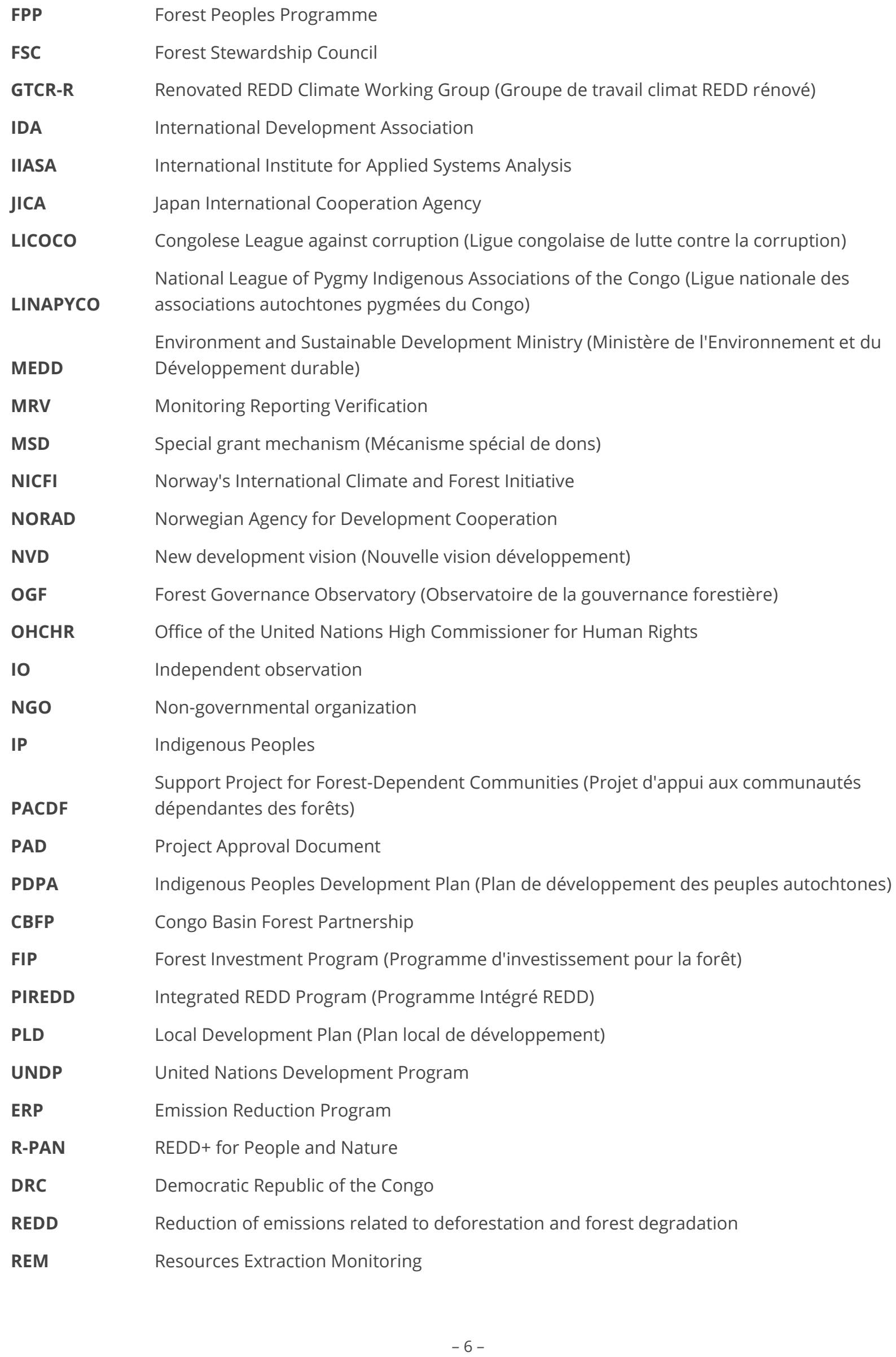


Indigenous Peoples Network for Forest Ecosystem Management in the DRC (Réseau des

REPALEF peuples autochtones pour la gestion des écosystèmes forestiers en RDC)

RFN Rainforest Foundation Norway

RFUK Rainforest Foundation UK

RRI Rights and Resources Initiative

NRN Natural Resources Network

SPAT Provincial Planning Scheme (Schéma provincial d'aménagement du territoire)

UNESCO United Nations Educational, Scientific and Cultural Organization

WWC Wildlife Works Carbon 


\section{Executive summary}

\section{REDD+ in Mai-Ndombe}

The province of Mai-Ndombe in the Democratic Republic of the Congo (DRC) has, in the last five years, become a REDD+ laboratory. In 2016, the Forest Carbon Partnership Facility (FCPF) approved the DRC's Emissions Reduction Program (ERP), focusing on this province. The Forest Investment Program (FIP) supports two integrated REDD+ programs, and numerous Central Africa Forest Initiative (CAFI) programs are also planned. REDD+ investments exceed US\$90 million in a 12.3 million hectares area, including 9.8 million forested hectares. The DRC is home to the second largest tropical forest in the world, storing more than 8 percent of the world's tropical forest carbon. Beyond conserving the forest, REDD+ programs aim to preserve them by addressing all the drivers of deforestation, while also fighting poverty and improving people's living conditions.

\section{Goals of this study}

This study aims to assess the cumulative risks and impacts of all REDD+ initiatives in Mai-Ndombe on the rights and subsistence of local communities and Indigenous Peoples, using existing tools while taking into account gray areas of the REDD+ process. Findings come from existing project documentation, field studies conducted in recent years, and a series of interviews with REDD+ stakeholders in Mai-Ndombe. The study provides a mapping of all existing and planned REDD+ initiatives in the province, as well as a cross-cutting contextual analysis of risks which connects REDD+ to human rights. This is followed by an assessment of these initiatives' cumulative impacts as well as of national and project strategies to address and reduce risks. It thus offers a perspective on the link between the accumulation of REDD+ initiatives and conflicts at different scales.

\section{Contextual risk analysis}

Significant REDD+ investments to combat climate change and poverty are being made in an already fragile context that poses substantial risks for the 1.8 million people in Mai-Ndombe province, their lands, and their natural resources. For this young province in a post-conflict country, governance remains a major issue. The decentralization policy is not yet fully effective and limits the provincial government's capacity. The legal framework that determines communities' rights remains complex and little-known, and the 1973 law which governs access to land does not secure the rights of communities in the territory. The arrival of new migrants looking for work and arable land, the increased demand for energy and resources, and continuing confusion over land rights all contribute to an increasing number of land conflicts in the province, increased pressures on the territory, and an increase in food insecurity. At the same time, the rights of the province's indigenous Pygmy peoples (about 73,000 individuals) are routinely violated despite being recognized in several international conventions. Similarly, the strong discrimination against rural and indigenous women, who lack access to key lands and resources, persists despite legal protections. The risks stemming from various REDD+ initiatives are considerable and deserve the attention of all key players given that the participation of local communities and Indigenous Peoples in decisions about their rights, 
their means of subsistence, and their ability to benefit from investments in the territory remains low.

\title{
Key findings
}

Fragile and incomplete governance infrastructure. There is no apparent coordination between the large number of REDD+ initiatives under development in the province. Moreover, the preparation phase has been declared over even though not all governance tools have been created and operationalized. An independent observer has not yet been mandated and the local governance of the projects suffers from a lack of attention as to the composition of the local development committees, which are not representative of the communities they speak for.

Lack of coherence between the emerging structure and the drivers of deforestation. The REDD+ approaches pursued in Mai-Ndombe make it impossible to address the structural factors-both current and future-responsible for deforestation. The strategies currently being considered lack perspective on the forest industry, the anticipated impacts of the migratory phenomenon, and the increased exploitation of resources that are not yet marketed, among other things.

\begin{abstract}
Absence of concrete measures to secure communities' land rights and reduce the risks of associated conflicts. The complex land dynamics in Mai-Ndombe are underestimated by all initiatives in the province. Little or no attention is given to: (i) the land insecurity of local communities and Indigenous Peoples; (ii) land grabbing and price inflation; (iii) customary practices and sharecropping; and (iv) the risks of conflict, displacement, and unlawful capture of REDD+ benefits. In addition, the land reform process is evolving independently of REDD+ governance consultations, and community forestry remains underutilized as an anchor for communities in REDD+.
\end{abstract}

\section{Limited integration of Indigenous Peoples, local communities, and women.}

Marginalized populations in Mai-Ndombe are not included as one of the enabling pillars of REDD+. Communities are poorly informed about the processes that have mainly been conducted in Kinshasa; FPIC is applied partially and unevenly; and the role of women in land management has been ignored, while they have been edged out of the governance of initiatives. In the absence of recognized land rights for rural communities and systematic and independent support for women's participation in decision-making bodies, the concurrence and accumulation of REDD+ initiatives run the risk of increasing the precarity of an already vulnerable population.

\section{Uncertainty regarding the beneficiaries and the achievement of co-development} objectives. The potentially negative impacts of REDD+ are poorly understood and there is currently no provision allowing communities to access the proposed benefits. Given the history of poor natural resource revenue sharing and the inadequacy of the proposed 
participatory approaches, the initiatives pursued will tend to favor the emergence of private actors, reduce the benefits for the poorest people, and reduce state accountability for forest conservation and community ownership of REDD+ goals.

\section{Conclusions and priorities for action}

The ambitions supported by REDD+ can only be realized if the living conditions of local populations are improved by the proposed actions, which can be accomplished by securing their rights over their lands and natural resources and respecting their human rights. Initiatives carried out under the auspices of international institutions require an assurance that the safeguards supported by the United Nations Framework Convention on Climate Change (e.g. the Cancun safeguards) will be considered and respected. However, in light of the cumulative risks and impacts associated with the multiplicity of REDD+ initiatives in Mai-Ndombe, our analysis reveals that the investments made to date would neither create the conditions necessary to achieve the objectives of the DRC'S REDD+ investment plan, nor comply with the Cancun safeguards that apply to all REDD+ countries and projects. In this sense, the minimum objective of not aggravating the situation of Indigenous Peoples and local communities is not achieved, and the measures taken to mitigate the risks are largely insufficient.

In order to reduce greenhouse gas emissions while contributing to the Sustainable Development Goals, the partners associated with the DRC's various REDD+ initiatives, especially the ERP, should prioritize the following actions:

1. Secure the land rights of local communities, Indigenous Peoples, and women to make them the primary beneficiaries of REDD+. Develop a fair and operational benefit sharing plan to accelerate community contributions to emissions reduction and sustainable territorial management through a new Homologation Regulation decree integrating the CFCLs.

2. Target the primary current and future drivers of deforestation and ensure a better match between the available legislative tools (e.g. maintaining the moratorium on logging concessions and putting a moratorium in place on conservation concessions) and the incentives provided under REDD+ (e.g. that REDD+ currently enables revenue capture by private actors without benefits to communities, while results-based payments are not adapted to community-based projects).

3. Finalize and operationalize key governance tools (recourse and feedback mechanism, benefit sharing plan, safeguards information system, independent monitoring mechanism) and strengthen the national and provincial REDD+ coordination structure.

4. Adopt existing conflict management measures for the whole province and develop a risk mitigation and identification system supported by the land reform process which 
leads to the recognition of community rights through the implementation of safeguards and the equitable sharing of benefits.

5. Ensure, at the local and provincial level, a better integration of Indigenous Peoples and women, who are currently being discriminated against in REDD+ decision-making processes, and provide systematic support for both women's participation and the recognition of Indigenous Peoples' rights. 


\section{Introduction}

The province of Mai-Ndombe, which covers 12.3 million hectares including 9.8 million hectares of forest, has become a REDD $+{ }^{1}$ laboratory in the Democratic Republic of the Congo (DRC) over the last five years, and attracted significant international attention. In 2016, the Forest Carbon Partnership Facility (FCPF) approved the DRC Emissions Reduction Program (ERP) for the province, and an Emission Reduction Payments Agreement (ERP A) is expected to be signed this year. The province will welcome, at least on paper, all the initiatives that are planned but not yet implemented, in all twenty interconnected projects and programs receiving REDD+ funding. The concentration of investments generated by this situation has materialized into a series of existing or planned policies, investment programs, private sector projects, and "integrated programs" as part of the DRC's REDD+ investment plan.

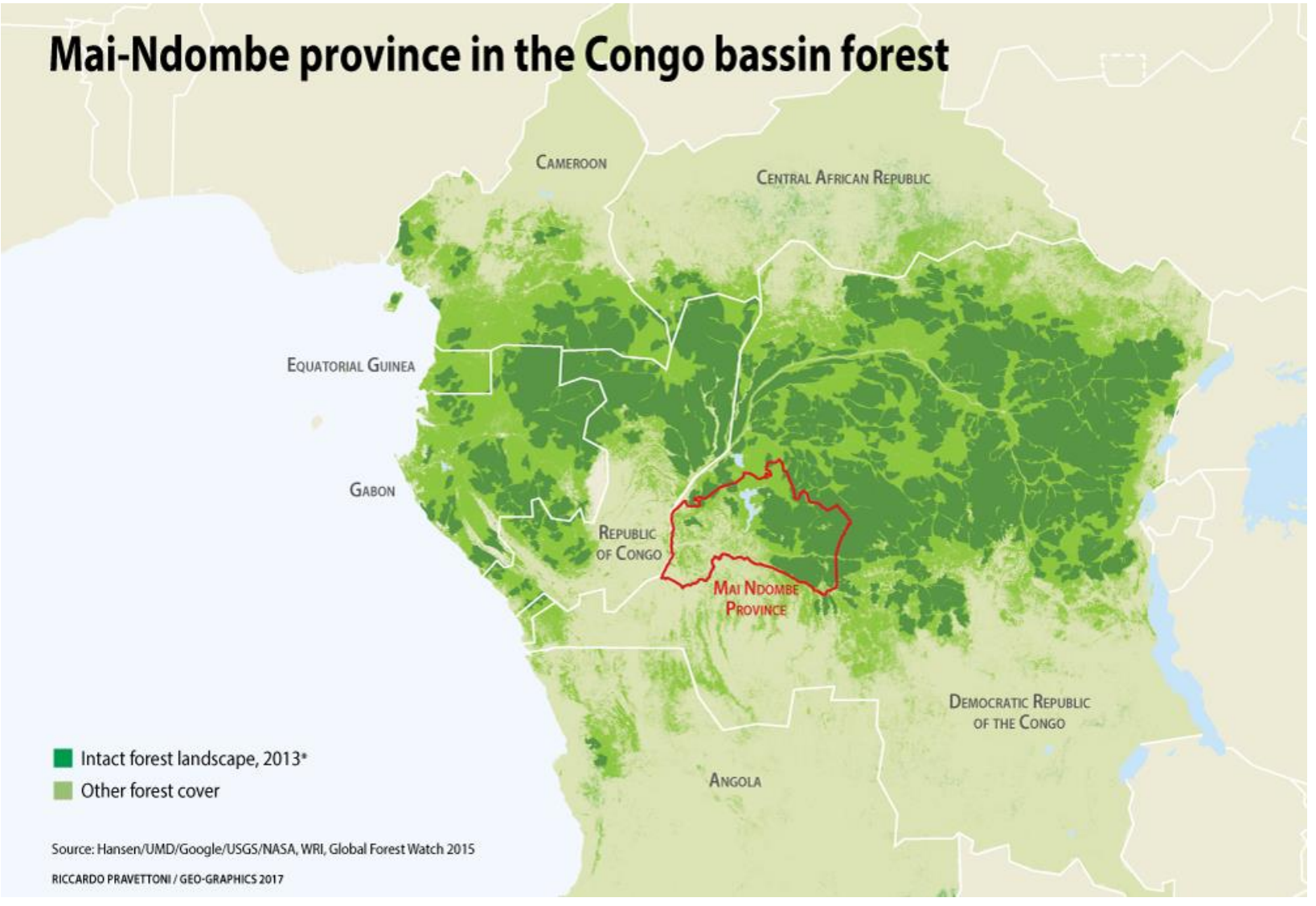

RRI has been supporting local actors in the DRC through various programs since 2009. These include support for land reform through the production of a basic land tenure study, support for the creation and activities of CACO, a consultation framework for civil society organizations toward land reform in the DRC, and the recognition of the land rights of local communities, women, and Indigenous Peoples in REDD+ initiatives. 
The analysis of the DRC Emission Reduction Program (ERP IN) concept note, conducted by RRI in 2016, revealed major concerns, particularly in terms of land rights, respect for free, prior, and informed consent (FPIC), women's rights, and benefit-sharing. Several international and national civil society organizations subsequently commented on the first version of the Emissions Reduction Program Document (ERP D) and raised similar concerns.

This study aims to evaluate, in view of both the existing tools and the gray areas of the REDD+ process, the cumulative risks and impacts of all REDD+ initiatives on the rights and means of subsistence of local communities and Indigenous Peoples in Mai-Ndombe. It was undertaken based on existing project documentation (project documents, reports, progress reports, etc.), field studies by all stakeholders in recent years, and a series of interviews with REDD+ stakeholders in MaiNdombe (project leaders, national and international civil society, external observers, and representatives of local communities and Indigenous Peoples). In particular, it offers:

1. A mapping of all REDD+ initiatives, present or planned, in the province (Chapter 1);

2. A cross-cutting analysis of contextual risks linking REDD+ to human rights (Chapter 2);

3. An evaluation of the cumulative impacts of the initiatives pursued to date, the conflicts present at different scales, and the strategies put in place at the national and local levels to reduce negative effects (Chapter 3); and

4. Conclusions and priorities for action to mitigate the risks associated with the implementation of REDD+ in Mai-Ndombe (Chapter 4).

While the approach is inclusive, emphasis is placed on larger programs, namely ERP, PIREDD, and CAFI programs. Special attention was also paid to the WWC conservation concession, the only REDD+ project certified to date, and the REDD+ Novacel-South Kwamouth pilot project, which also aims to test the implementation of REDD+ on land and eventually generate carbon credits. 


\section{Net forest loss and demography in the DRC}

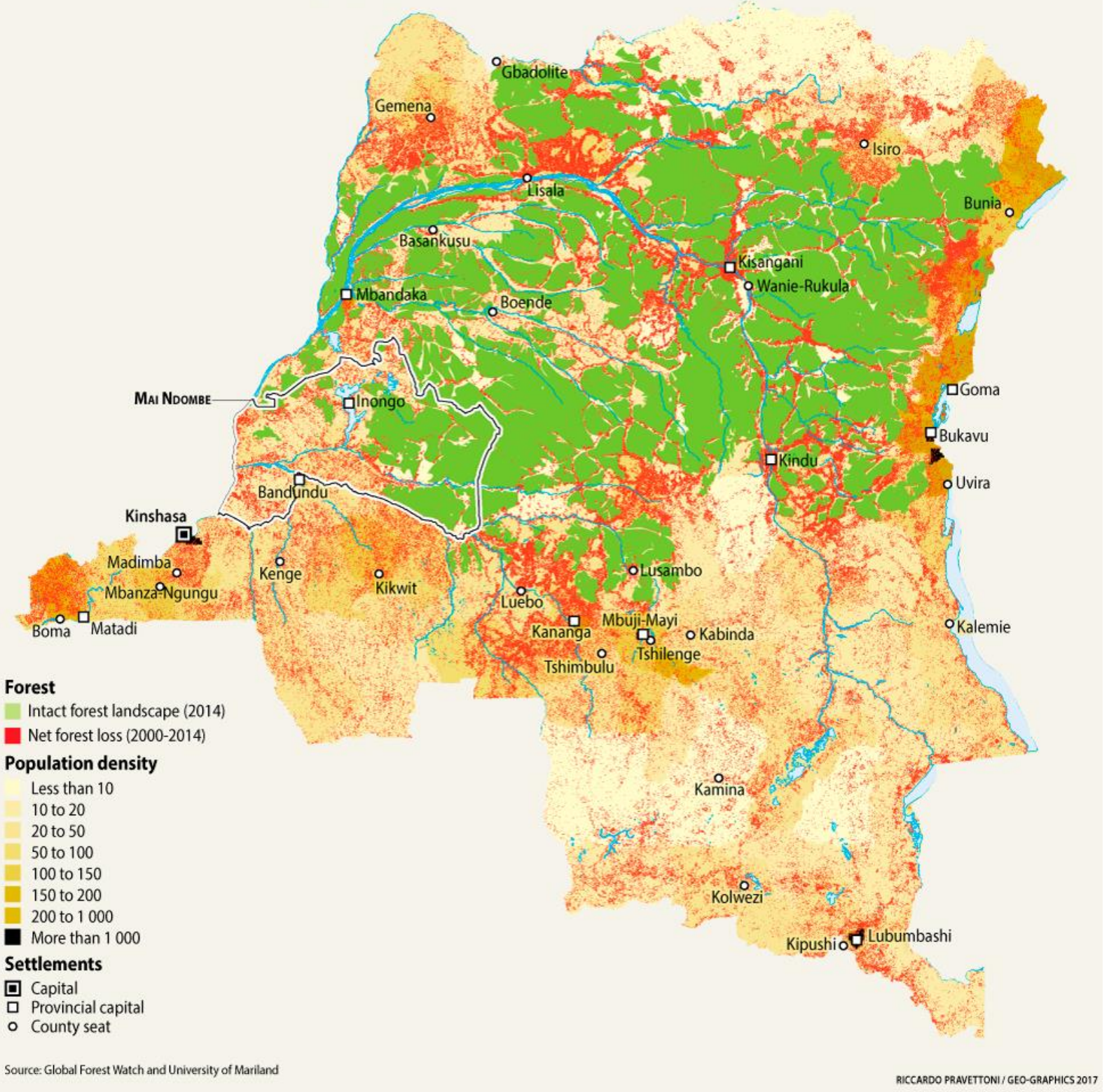

The concentration of REDD+ initiatives can be attributed primarily to the geographical location of this young province. Created in $2005^{2}$, the provincial government was established in 2015 . Located on the western edge of the Congo Basin's great equatorial forest, north of the province of Kinshasa, it is crisscrossed by a river network leading to the Congo River, as well as by a national road which is passable but in very bad condition. It functions as a supply area for agricultural and wood products for Kinshasa. The region is close enough to the capital for the forest cover to be threatened by 
commercial pressure, but far enough away that 87 percent of its territory is still tropical rainforest, 37 percent of it intact forest landscape. At 0.53 percent each year ${ }^{3}$, its rate of deforestation is low. However, these figures require clarification in each territory: the realities of the south of the province, the plateau, which is agricultural land and savannah, differ widely with the north, where there are forests with shrub-filled and herbaceous savannahs as well as flooded and semi-flooded soils. All of these ecosystems form a Ramsar biodiversity hot spot and have strong potential to combat climate change through REDD+.

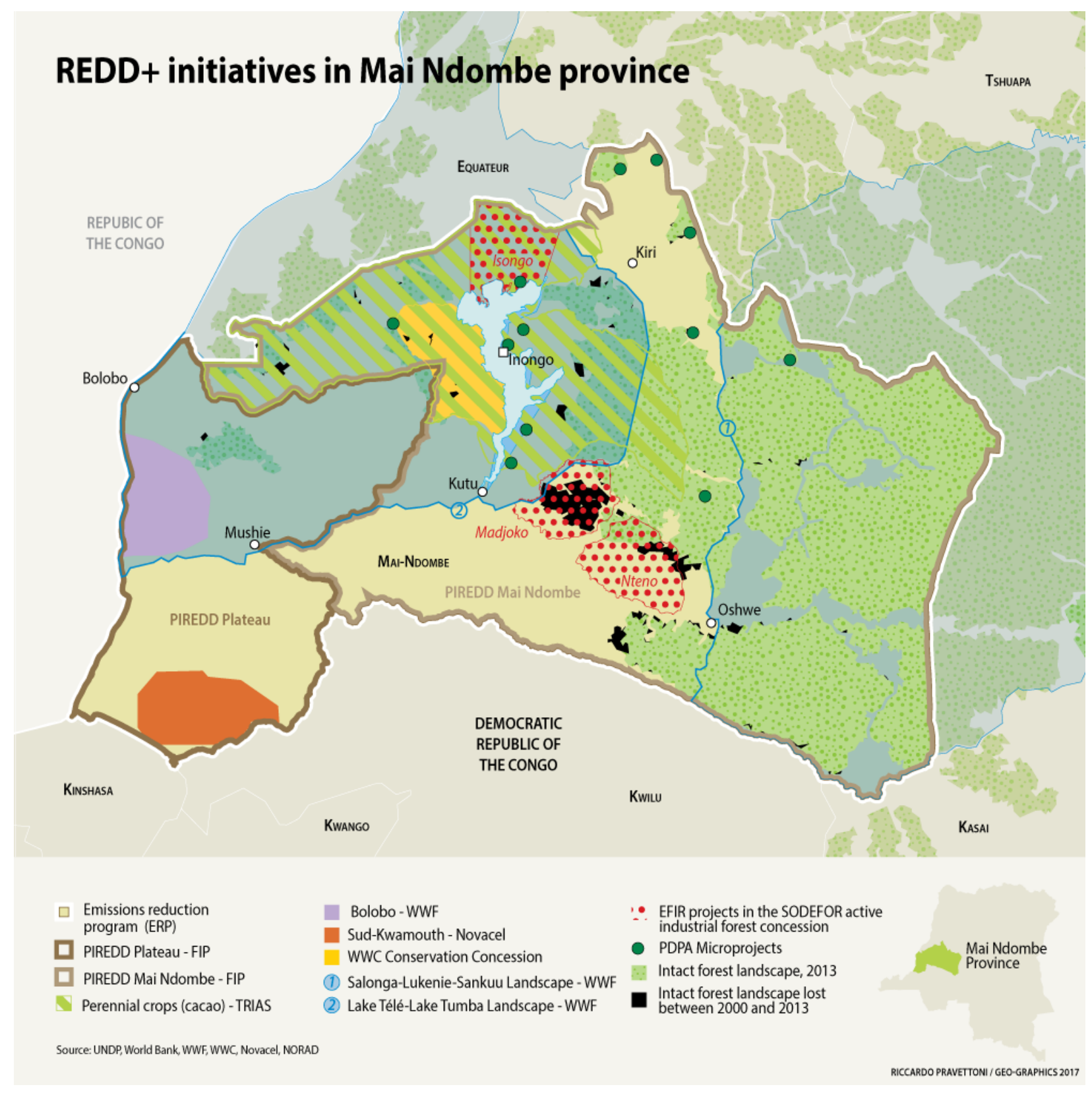

The Plateau Integrated REDD+ Program (PIREDD), managed by the Forest Investment Program (FIP) and implemented locally by WWF, was launched in late 2016, and an integrated REDD+ program 
extending to the rest of the province (PIREDD Mai-Ndombe) has been approved by CAFI. Other initiatives to support civil society or commercial endeavors are also funded by CAFI. Implemented at the national level, land reform and land use reform are or will also be active at the provincial level, the former having selected Mai-Ndombe as a pilot province, and the latter empowering both PIREDDs for its implementation.

A multitude of private actors are present in the province of Mai-Ndombe beyond the three REDD+ flagship funds in the Democratic Republic of the Congo (FIP, FPCF, CAFI). Private REDD+ conservation concessions (WWC) and plantation REDD+ pilot projects (Novacel South Kwamouth) are already underway. WWF-DRC is implementing a series of projects (in Bolobo and in the CARPE landscapes) in addition to being the local implementing agency in the Plateau PIREDD. Other private companies are positioning themselves to receive REDD+ funds and eventually obtain a certification allowing them to generate carbon credits, and thus benefit from additional revenues to their activities. Other initiatives benefiting from public REDD+ funding support activities benefiting Indigenous Peoples' implementation of REDD+ (PDPA, PACDF) or at strengthening the participation of communities and civil society (WWF programs funded by NORAD, CAFI's civil society program).

At the local level, the approach taken by World Bank-funded programs is to form local development committees that bring together community members and serve as consultative bodies for communities in many programs. The implementation of CLD has already started in the PIREDD Plateau, but is not yet effective throughout the province or in all projects. 


\section{Actors and initiatives connected to REDD+ in the province of Mai Ndombe}

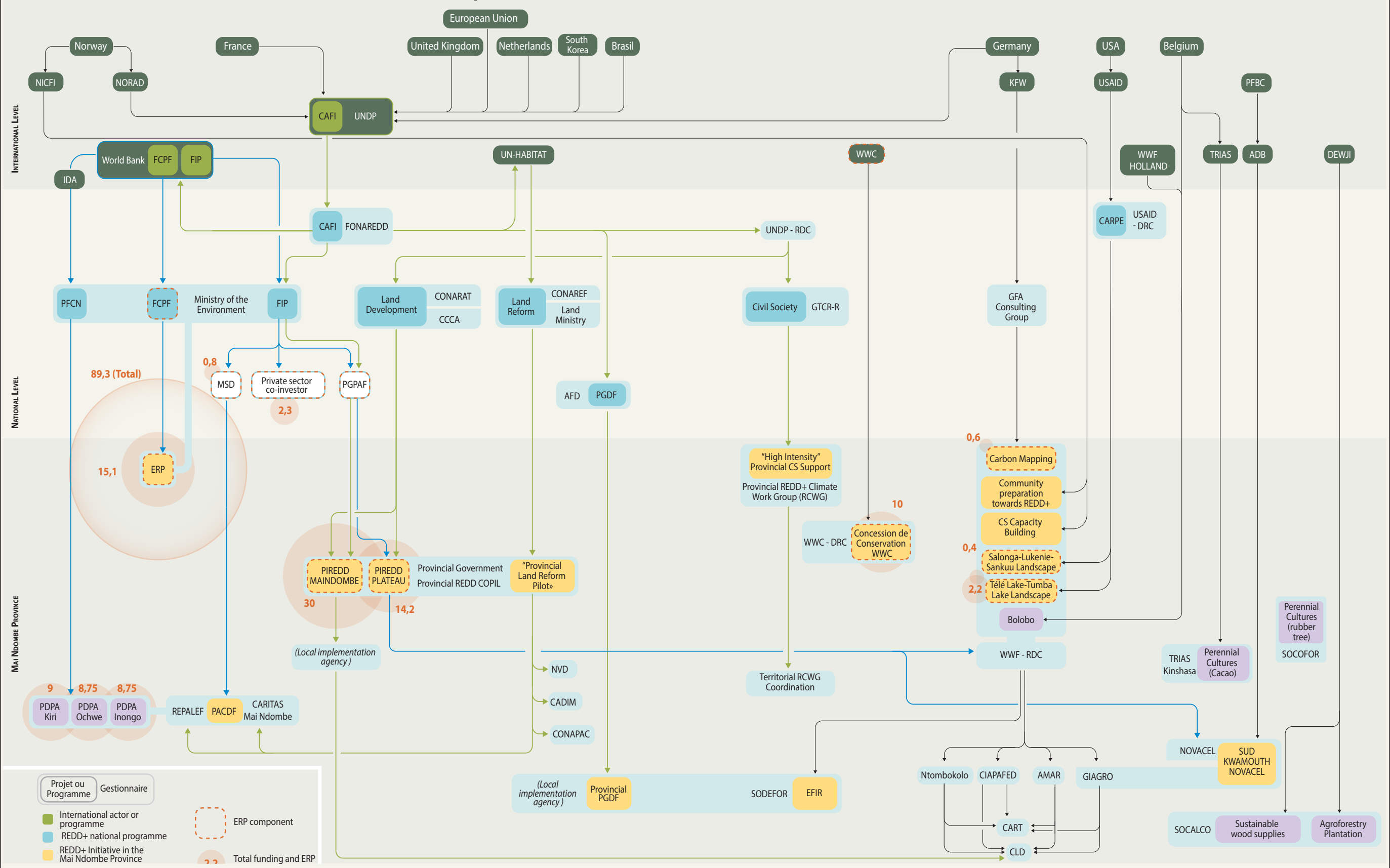


Table 1. Synthesis of REDD+ Initiatives in Mai-Ndombe

\begin{tabular}{|c|c|c|c|c|c|}
\hline $\begin{array}{l}\text { Type of } \\
\text { initiative }\end{array}$ & Initiative & Main activities & Governance structure & Applicable safeguard policy & $\begin{array}{l}\text { Period of } \\
\text { activity }\end{array}$ \\
\hline \multirow[t]{2}{*}{$\begin{array}{l}\text { World Bank } \\
\text { REDD+ } \\
\text { Programs }\end{array}$} & $\begin{array}{l}\text { Emissions reduction } \\
\text { program (ERP) - } \\
\text { FCPF } \\
\text { (ERP D approved, } \\
\text { ERP A not yet signed) }\end{array}$ & $\begin{array}{l}\text { ERP is the first large-scale REDD+ program } \\
\text { in the Congo Bassin. It will be carried out } \\
\text { through a purchase and sales contract for } \\
\text { emissions reductions (ERP A / ERP A) } \\
\text { yielding a potential total reduction of } 60 \\
\text { million tonnes of CO2 between } 2017 \text { and } \\
\text { 2022. It will be a jurisdictional model for } \\
\text { green development at the provincial level, } \\
\text { offering results-based alternatives and } \\
\text { incentives to face the challenges of climate } \\
\text { change, reduce poverty, conserve resources } \\
\text { and protect biodiversity. }\end{array}$ & $\begin{array}{l}\text { The Ministry of Environment and } \\
\text { Sustainable Development (MEDD) and } \\
\text { the provincial government of Mai- } \\
\text { Ndombe will sign the ERP A. The } \\
\text { program will be implemented by the } \\
\text { provincial government, with technical } \\
\text { support from a program management } \\
\text { unit (yet to be recruited) and a } \\
\text { provincial REDD + steering committee } \\
\text { composed of representatives from } \\
\text { ministries, civil society, indigenous } \\
\text { peoples, the private sector and the } \\
\text { different agencies executing the } \\
\text { program. The monitoring and } \\
\text { evaluation will be carried out by the } \\
\text { MEDD through the "Direction des } \\
\text { inventaires et de l'aménagement } \\
\text { forestier" (DIAF), the local consultation } \\
\text { platforms (CARG and CLD), and } \\
\text { undertaken under the PIREDDs as well } \\
\text { as by appointed observers, auditors } \\
\text { and independent examiners. }\end{array}$ & $\begin{array}{l}\text { National social and environmental REDD } \\
\text { + standards developed and validated in } \\
\text { January 2016; indicator grid and } \\
\text { synthesis of the safeguards information } \\
\text { system developed by the CNREDD with } \\
\text { the support of CCBA and EFI in } 2016 \text { (but } \\
\text { not yet validated); National } \\
\text { Environmental and Social Management } \\
\text { Framework (CGES), and its policy and } \\
\text { sector planning documents, developed } \\
\text { by the FIP; specific risk management } \\
\text { matrix, which is to be prepared under } \\
\text { this program but does not yet exist. }\end{array}$ & $\begin{array}{l}\text { Upon signing of } \\
\text { the ERP A. ERP D } \\
\text { planned activities } \\
\text { from } 2016-2020 \text {, } \\
\text { and set a } \\
\text { reduction } \\
\text { deadline for } \\
\text { 2021. Recent } \\
\text { documents } \\
\text { forecast a } 2017 \text { - } \\
\text { 2022 reporting } \\
\text { period. }\end{array}$ \\
\hline & $\begin{array}{l}\text { Programme Intégré } \\
\text { REDD+ Plateau } \\
\text { (PIREDD Plateau) - } \\
\text { PIF } \\
\text { (active) }\end{array}$ & $\begin{array}{l}\text { The PIREDD Plateau is a precursor of } \\
\text { REDD+ in one of the two eldest district of } \\
\text { Mai-Ndombe, the Plateau. It addresses a } \\
\text { group of direct and indirect drivers of } \\
\text { deforestation through agroforestry } \\
\text { activities, capacity building for local public } \\
\text { services, infrastructure restoration, support } \\
\text { to natural resources management plans } \\
\text { and to the structuring of CLD on the } \\
\text { territories. Participatory mapping activities }\end{array}$ & $\begin{array}{l}\text { The FIP coordination unit is integrated } \\
\text { into the MEDD. WWF-DRC was } \\
\text { recruited as a local implementing } \\
\text { agency and subcontracted four } \\
\text { organizations, each responsible for a } \\
\text { territory in which they accompany the } \\
\text { technical services and give structure to } \\
\text { the CLDs and the CARGs. The latter } \\
\text { make decisions at the community level } \\
\text { and monitor and evaluate project }\end{array}$ & $\begin{array}{l}\text { Socio-environmental safeguards of the } \\
\text { PGAPF (component } 1 \text { of the Forest } \\
\text { Investment Fund), CGES and related } \\
\text { documents; operational policies of the } \\
\text { World Bank. }\end{array}$ & $\begin{array}{l}2015- \\
2020 \text { Active in } \\
\text { the province } \\
\text { since } 2016 .\end{array}$ \\
\hline
\end{tabular}




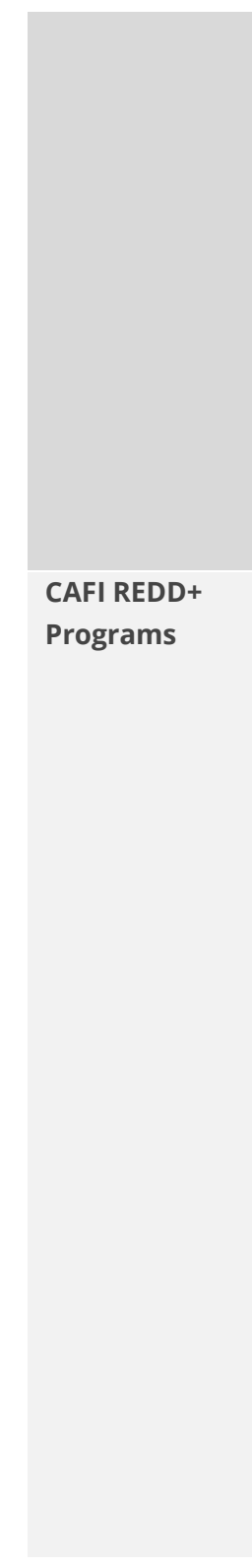

are planned but have not yet been undertaken.

Projet d'appui aux communautés dépendantes de la forêt (PACDF) - MSD (active)

\section{UN-Habitat Land}

Reform

(not yet active at the provincial level)
Targets indigenous peoples specifically, through a special donation mechanism. It also strengthens: governance in identified spaces, representation, and capacity to allow indigenous communities to establish sustainable forest management microprojects.

The land reform, initiated by the government in 2012, was relaunched on March 30, 2016 by the Coordination nationale de la réforme foncière (CONAREF) steering committee. The province of MaiNdombe was chosen as pilot province fo the reform, in order to test the implémentation of processes securing land rights on the ground, supported by a land information system amongst the communities. indicators in the field. The provincial steering committee, chaired by the provincial Minister of the Environment, is responsible for the orientation, monitoring and evaluation of both PIREDDS.

The PACDF is implemented by the national Catholic NGO Caritas Congo, in partnership with REPALEF. It operates in four specific sites in MaiNdombe, identified as sensitive and priority forest areas for community management.

This program is implemented at the national level by UN-Habitat, in partnership with the Ministry of Land Affairs and CONAREF, a structure bringing together representatives of different sectoral ministries. At the provincial level, it will be overseen by the provincial Ministry of Land Affairs, a provincial reform coordination and a rural land observatory. The program will collaborate with civil society organizations involved in the World Bank's ERP and PIREDD, such as REPALEF, the provincial federations of farmers' organizations in Congo, the diocese of Inongo and various CSOs. A consultation framework bringing together all civil society actors concerned with land issues (NRN CODELT, CONAPAC, LINAPYCO and CFLEDD), supported by RRI, is also accompanying the reform at the national level.

World Bank operational policies, particularly P.O. 4.10 specifically targeting indigenous peoples.

Safeguard instruments from EESS; CGES measures and related documents; national environmental and social standards. The Land Reform

Accompaniment Program, however, specifies that these tools are still at the field test phase, and that a safeguards management plan will be developed and shared later.
National

program: 2017-

2020
2016-2021 


\begin{tabular}{|c|c|c|c|c|c|}
\hline & $\begin{array}{l}\text { Land Development } \\
\text { Reform - UNDP } \\
\text { (active in the Plateau } \\
\text { district) }\end{array}$ & $\begin{array}{l}\text { The program aims to support land } \\
\text { development reform, with the objective of } \\
\text { reducing the pressures different sectors' } \\
\text { use of land have on the forest. At the } \\
\text { national level, it will support the } \\
\text { development of a national policy and the } \\
\text { strengthening of the regulatory and legal } \\
\text { framework. At the provincial level, the } \\
\text { reform will support the elaboration of } \\
\text { provincial land development plans (SPAT) } \\
\text { and local development plans (PLD). }\end{array}$ & $\begin{array}{l}\text { This program is implemented by the } \\
\text { UNDP, with the oversight of the } \\
\text { ministère de l'Aménagement du } \\
\text { Territoire et de la Coordination } \\
\text { nationale de la réforme de } \\
\text { l'aménagement des territoires, which } \\
\text { brings together representatives of all } \\
\text { sectoral ministries. At the provincial } \\
\text { level, the program delegates the } \\
\text { implementation of land-use planning } \\
\text { by PIREDD, which entrusts it to their } \\
\text { local implementing agencies, WWF in } \\
\text { the case of PIREDD Plateau. }\end{array}$ & $\begin{array}{l}\text { Safeguard instruments from EESS; CGES } \\
\text { measures and related documents; } \\
\text { national environmental and social } \\
\text { standards. The program also plans to } \\
\text { specifically divide the safeguarding } \\
\text { measures according to the orientations } \\
\text { of territorial planning to ensure that they } \\
\text { are taken into account in carrying out } \\
\text { this project. }\end{array}$ & $\begin{array}{l}2017- \\
2021 \text { Supported } \\
\text { by the PIREDD, it } \\
\text { is already active } \\
\text { within the } \\
\text { framework of the } \\
\text { PIREDD Plateau }\end{array}$ \\
\hline & $\begin{array}{l}\text { Projet de gestion } \\
\text { durable des forêts - } \\
\text { AFD } \\
\text { (not yet validated) }\end{array}$ & $\begin{array}{l}\text { At the national level. the program aims to } \\
\text { elaborate the forestry policy, update the } \\
\text { forestry code, fight illegal logging and lift } \\
\text { the conditions of the } 2005 \text { moratorium. At } \\
\text { the local level, it will assist industrial } \\
\text { farmers to bring their farms into } \\
\text { compliance, reduce impact logging, } \\
\text { experiment with concessions of } \\
\text { decentralized territorial entities and } \\
\text { communities, and organize and train } \\
\text { artisanal miners. }\end{array}$ & $\begin{array}{l}\text { The Agence française de } \\
\text { développement, which is responsible } \\
\text { for the implementation of the } \\
\text { program, will recruit a company to do } \\
\text { it. This company will work, in a matter } \\
\text { which is still unknown, with industrial } \\
\text { and artisanal loggers and local } \\
\text { communities. }\end{array}$ & $\begin{array}{l}\text { The backup tool produced by the EESS; } \\
\text { CGES measures and related documents; } \\
\text { national environmental and social } \\
\text { standards. }\end{array}$ & $2017-2021$ \\
\hline \multirow[t]{2}{*}{$\begin{array}{l}\text { Private sector } \\
\text { REDD+ } \\
\text { projects }\end{array}$} & $\begin{array}{l}\text { WWC Conservation } \\
\text { grant } \\
\text { (active) }\end{array}$ & $\begin{array}{l}\text { In 2012, the ERA company, whose shares } \\
\text { have now been bought by WWC, was } \\
\text { awarded a concession. They pledged not to } \\
\text { log it and fight against deforestation, mainly } \\
\text { the reduction of slash-and-burn agriculture } \\
\text { and charcoal production. This project is } \\
\text { currently the only REDD + project certified } \\
\text { in the province of Mai-Ndombe capable of } \\
\text { issuing and selling carbon credits on the } \\
\text { voluntary market. }\end{array}$ & $\begin{array}{l}\text { WWC is a Canadian company with an } \\
\text { office in Kinshasa. It is also present in } \\
\text { the project area itself and works with } \\
\text { communities to encourage them to } \\
\text { change those practices which result in } \\
\text { deforestation. }\end{array}$ & $\begin{array}{l}\text { (...) its carbon credits in the context of } \\
\text { the ERP, WWC will have to demonstrate } \\
\text { its respect of all safeguard measures } \\
\text { applicable to the ERP. }\end{array}$ & $2011-2041$ \\
\hline & $\begin{array}{l}\text { Projet Novacel Sud- } \\
\text { Kwamouth }\end{array}$ & $\begin{array}{l}\text { A REDD + pilot project supported by the } \\
\text { Congolese government, it aims to develop }\end{array}$ & $\begin{array}{l}\text { The project is co-managed locally by } \\
\text { Novacel, a private company, and its }\end{array}$ & $\begin{array}{l}\text { Emissions reduction program. In its first } \\
\text { phase, it responded to the ADB's }\end{array}$ & $2012-2020$ \\
\hline
\end{tabular}




\begin{tabular}{|c|c|c|}
\hline & (active) & $\begin{array}{l}\text { agroforestry based on acacia and cassava } \\
\text { (plantation, savanna regeneration, and } \\
\text { development of local infrastructures) in a } \\
\text { highly degraded zone of Kinshasa's } \\
\text { firewood supply area. The project has two } \\
\text { components: industrial plantation and } \\
\text { community plantation. Lacking financial } \\
\text { means, the necessary steps towards the } \\
\text { certification are not yet started. }\end{array}$ \\
\hline \multirow{4}{*}{$\begin{array}{l}\text { REDD + } \\
\text { projects } \\
\text { These } \\
\text { projects are } \\
\text { not } \\
\text { considered } \\
\text { REDD +, but } \\
\text { contribute to } \\
\text { it either } \\
\text { through } \\
\text { enabling } \\
\text { measures or } \\
\text { their } \\
\text { potential to } \\
\text { generate } \\
\text { emission } \\
\text { reductions. }\end{array}$} & $\begin{array}{l}\text { Production de cacao } \\
\text { et cultures pérennes } \\
\text { - Trias } \\
\text { (active) }\end{array}$ & $\begin{array}{l}\text { A planting and marketing project for cacao } \\
\text { by-products. It also helps build depots } \\
\text { which stock and help market agricultural } \\
\text { products manufactured in Inongo. As } \\
\text { perennial cultures have been identified as a } \\
\text { REDD+ lever, this project could benefit from } \\
\text { REDD+ financing and generate emissions } \\
\text { reductions. }\end{array}$ \\
\hline & $\begin{array}{l}\text { Exploitation } \\
\text { forestière à impact } \\
\text { réduit - SODEFOR } \\
\text { (active) }\end{array}$ & $\begin{array}{l}\text { SODEFOR implements reduced impact } \\
\text { logging (EFIR) practices to obtain FSC } \\
\text { certification in three of its concessions } \\
\text { (Nteno, Madjoko and Isongo). The company } \\
\text { plans to extend this effort to all of its } \\
\text { concessions. }\end{array}$ \\
\hline & $\begin{array}{l}\text { Projet modélisation } \\
\text { carbone - WWF } \\
\text { (active) }\end{array}$ & $\begin{array}{l}\text { The project aims to determine the carbon } \\
\text { stocks, emissions and opportunities to } \\
\text { reduce them in the province of Mai- } \\
\text { Ndombe. In this context, WWF undertook } \\
\text { this analysis of two SODEFOR concessions, } \\
\text { for example. }\end{array}$ \\
\hline & $\begin{array}{l}\text { Activités WWF à } \\
\text { Bolobo } \\
\text { (active) }\end{array}$ & $\begin{array}{l}\text { As part of the For People and Nature REDD } \\
\text { project, WWF piloted a set of activities in the } \\
\text { Bolobo area. It includes the participation of } \\
\text { communities in the REDD + process, the }\end{array}$ \\
\hline
\end{tabular}

partner GI-Agro. GI-Agro is in charge of the community component and works with farmers' groups. The project's logical framework announces a target population of "10,000 rural enclave families, or 50,000 people, established in southern Kwamouth territory." The project as initially conceived is

completed (CBFP financing via the ADB ended in 2016), but it was taken over by the PIREDD Plateau, with financing from the World Bank.

The Belgian NGO Trias works locally with rural agricultural management councils.

SODEFOR is accompanied by WWFDRC in this work. WWF-DRC is itself financed by FfW.

WWF and its German partner GFA Consulting are responsible for the evaluation of activities which were preselected by the project.

WWF is the project manager. It is working in part with a local NGO,

Mbou Mon Tour, with whom conflicts have occurred during the last two safeguarding measures. Now integrated to the PIF, it answers to safeguards developed in the context of PIREDD Plateau.

If the project becomes REDD +, it will Since 2010 have to respond to the REDD + safeguards applied as part of the emission reduction program. To date, however, there are no opposable measures.

If the project becomes REDD +, it will Since 2010 have to respond to the REDD + safeguards applied as part of the emission reduction program. To date, however, there are no opposable measures.

If the project becomes REDD +, it will have to respond to the REDD + safeguards applied as part of the emission reduction program. To date, however, there are no opposable measures.

If the project becomes REDD +, it will 2013-2020 have to respond to the REDD + safeguards applied as part of the emission reduction program. To date, 
effective reduction of deforestation by $50 \%$ by 2020 and information sharing. Among the ongoing and planned activities, WWF is working on eco-tourism (especially because of the presence of bonobos on the area).

\begin{tabular}{|c|c|}
\hline $\begin{array}{l}\text { Préparation des } \\
\text { communautés à la } \\
\text { REDD+ - WWF } \\
\text { (active) }\end{array}$ & $\begin{array}{l}\text { This project supports participatory } \\
\text { processes and activities aimed at creating a } \\
\text { national consensus around REDD +. It does } \\
\text { so by involving local communities in REDD + } \\
\text { initiatives, policies and measures, to enable } \\
\text { socially and politically sustainable } \\
\text { outcomes. Training and empowerment of } \\
\text { local communities and indigenous peoples } \\
\text { is achieved through strengthening their } \\
\text { control of their territories. }\end{array}$ \\
\hline $\begin{array}{l}\text { Renforcement des } \\
\text { capacités de la } \\
\text { société civile - WWF } \\
\text { (active) }\end{array}$ & $\begin{array}{l}\text { This program is a support to the } \\
\text { governance of REDD + at the national level. } \\
\text { It will organize workshops and trainings in } \\
\text { Mai-Ndombe province aimed at } \\
\text { strengthening the capacity of the society } \\
\text { and the provincial steering committee to } \\
\text { participate in REDD + related decisions. }\end{array}$ \\
\hline $\begin{array}{l}\text { Paysage CARPE } \\
\text { Salonga-Lukenie- } \\
\text { Sankuru - WWF } \\
\text { (active) }\end{array}$ & $\begin{array}{l}\text { CARPE works on sustainable forest } \\
\text { management, wildlife conservation, } \\
\text { structuring local communities, empowering } \\
\text { CLDs in managing land use and } \\
\text { development plans, and REDD + activities in } \\
\text { eight natural forest landscapes rich in } \\
\text { carbon and biologically sensitive resources. } \\
\text { WWF also raises awareness among forest } \\
\text { workers about the REDD + certification and } \\
\text { its project implementation in forest } \\
\text { concessions. }\end{array}$ \\
\hline
\end{tabular}

years over the activities to be carried out and the methodology. WWF is planning, within the framework of the ERP, to bring its project closer to

Novacel company's project in South Kwamouth, in order to ensure a return on its carbon performance. The local partner has refused this.

This project, funded by NORAD

internationally, empowers the national

WWF organization in each country to

be responsible for the project. The

national organization works closely

with local authorities, particularly CN-

REDD, the provincial government of

Mai-Ndombe, but also Moabi and the CARPE program.

Funded by NORAD, this program is implemented by WWF-DRC.

CARPE has, since 1995, been the US Government's main climate change mitigation program in Africa. It is implemented by different

conservation NGOs, each responsible for a "landscape" and answering to USAID. WWF-DRC is responsible for this landscape. however, there are no opposable measures.

If the project becomes REDD +, it will 2016-2020 have to respond to the REDD + safeguards applied as part of the emission reduction program. To date, however, there are no opposable measures.

If the project becomes REDD +, it will have to respond to the REDD + safeguards applied as part of the emission reduction program. To date, however, there are no opposable measures.

To date, however, there are no 2013opposable REDD+ measures. However, the US Forcing Assistance Act, which 2018 (according to the current applies to all US-funded development aid, specifies that local communities and indigenous peoples must be involved in Landscape Agreement) the design of any conservation

intervention. 
Paysage CARPE lac

Télé - Lac Tumba -

WWF

(active)

Approvisionnement

durable et

agroforesterie -

SOCALCO

(active)

Production d'Hévéa -

Société Congo Forêt

(active)
See Salonga-Lukenie-Sankuru landscape. consumed in DRC. It sources wood in Mai-

Ndombe, and wants to increase its

production capacity while simultaneously setting up a sustainable supply system. It proposes reforestation projects to supply itself in a sustainable fashion and garden patches with Mai-Ndombe communities, through agroforestry projects.

The company restored the old rubber plantations of Inongo and Lukenie and uses them to turn dry rubber into rubber and palm oil into fuel, through a processing unit in Bandundu-Ville. These perennial crops could generate carbon credits under the ERP.

See Salonga-Lukenie-Sankuru landscape.

SOCALCO is a private company owned by the Dewii International Group,

based in Dubai.

\section{As a private operator and holding a}

land title for its agroforestry

concession, the company its

responsible for its plantations'

management.
If the project becomes REDD +, it will have to respond to the REDD + safeguards applied as part of the emission reduction program. To date, however, there are no opposable measures.

If the project becomes REDD +, it will have to respond to the REDD + safeguards applied as part of the emission reduction program. To date,

however, there are no opposable measures.
Since 2012

Since at least 2015 


\section{Contextual risk analysis}

\subsection{Governance: A major challenge for a new province in a post-conflict country}

\section{The national context: political instability}

Little specific information is available on the governance of Mai-Ndombe, whose government was set up in 2015. However, national-level observations can be applied. The 2014 universal periodic review identified serious legal and institutional weaknesses that preclude respect for human rights and good governance in the country. ${ }^{4}$ The main factors driving the country's governance crisis include recurring political crises, inadequate infrastructure, an underdeveloped regulatory environment, lack of institutional capacity, and weak rule of law. ${ }^{5}$ Political instability is latent, as evidenced by its ranking in the World Bank's "political stability and lack of violence"6 governance index, which is very weak (3rd percentile) and has not progressed since 2005. This index indicates that the government is vulnerable and likely to be destabilized or overthrown unconstitutionally or violently. The recent uprisings against the current government are a testament to this fragility. When presidential elections, initially scheduled for 2016, were ultimately delayed and the president refused to relinquish power, the opposition groups initially rose up before temporarily accepting his stay in office. The organization of the next elections is therefore eagerly awaited, although a date and transitional process have yet to be defined.

\section{Decentralization is not yet in effect, undermining the effectiveness of the provincial political and administrative authorities}

The DRC's decentralization policy is not yet effective and observers in the field report that the administrations of decentralized territorial entities (territory, sector, chiefdom, grouping, etc.) are not yet fully in place, trained, or financed by the State. In Inongo, the provincial capital, the provincial administration lacks infrastructure and premises for its offices. Moreover, it suffered for several months from the absence of its governor, who was elected in April 2016 but did not appoint provincial "provisional" ministers until September, ${ }^{7}$ thereby hindering the monitoring of the entire political-administrative portfolio. The Ligue congolaise de lutte contre la corruption (Congolese League Against Corruption, or LICOCO) also reports significant delays in the payment of government officials' salaries, as well as particularly low salaries for strategic positions (linked for example to the validation of a land allocation) within the Mai-Ndombe provincial administration. These factors erode the administrative staff and make them particularly vulnerable to corruption. This is part of a national context of low state efficiency, low government capacity to formulate and implement sound and consistent policies and regulations, and weak rule of law as, according to the World Bank's governance indicators, all of these indicators vary between the 3rd and 6th percentile. ${ }^{8}$

\section{Pressure on political opponents, the media, and civil society}

Freedom of expression and the right to information remain under threat at the national level, despite being recognized within the Constitution ${ }^{9}$ and by an implementing decree. ${ }^{10}$ The criminalization of defamation, which allows for the imprisonment of any discloser, is pointed to by UNESCO and CESCR as a strong barrier to free information. ${ }^{11}$ Increasing repression by the Congolese government against politicians and civil society actors was reported by Amnesty International in 2016. In this context, they face many constraints and intimidation, and run a great 
risk of harassment and arrest. ${ }^{12}$ The government's violent response to protests against the nonholding of elections demonstrated the government's capacity to use armed forces against its citizens. In Inongo, a prospectus was issued by the province's special commissioner banning any political rally. A spokesman for the provincial government said his decision was "impartial" and was only meant to "prevent public disorder in the province."13 This decision, however, demonstrates strong pressure on political opponents, which is not without impact on the ability of civil society to play its watchdog role and the freedom of communities to give or withhold consent for REDD+ initiatives.

\section{A historic absence of equitable sharing of natural resource revenues}

The Congolese Constitution stipulates that every Congolese person has the right to enjoy the nation's wealth and that the State has the duty to redistribute the royalties it receives from these riches equitably. ${ }^{14}$ Yet the DRC's abundance of natural resources (timber, diamonds, minerals, oil, etc.) has historically not benefited Congolese citizens; rather, exploitation of these resources during colonialism and afterward created an environment of corruption and conflict. Numerous studies conducted by Global Witness attest to how few of the benefits of natural resource exploitation are shared with local communities. Between 2013 and 2015, more than US\$750 million in mining revenues slipped away from the Congolese treasury. ${ }^{15}$ The opaque mining agreements concluded between the state and companies as well as the mismanagement of tax agencies and financial arrangements through foreign investors' offshore companies ${ }^{16}$ explain this flight of capital. This occurred despite the fact that the DRC has belonged to the Extractive Industries Transparency Initiative (EITI) since 2014. ${ }^{17}$ Without a significant change in governance, the risk of nonredistribution of REDD+ revenues is extremely high, despite the considerable investments made by UN-REDD+ and the FCPF during the REDD+ preparatory phase. In particular, the stages concerned with determining forest and carbon rights, determining carbon baselines and the benefit sharing plan, and the perception and management of REDD+ revenues are likely to be the subject of opaque agreements that undermine local communities' access to the benefits of REDD+.

\section{Corruption, an endemic risk}

In 2016, the NGO Transparency International ranked the Democratic Republic of the Congo 156th most corrupt out of 176 countries. It notes in particular that the natural resources sector is associated with widespread corruption, resulting in violence, insecurity, and discontent among the population. Bureaucratic and administrative corruption is the most widespread form of corruption across the country, with informal payments to access markets or public transactions common. ${ }^{18}$ An anti-corruption law was passed in 2004, ${ }^{19}$ but reports and civil society organizations alike agree on the lack of a strong political will to remedy corruption and enforce these legal provisions effectively. ${ }^{20}$ The country's generalized corruption poses a risk to the entirety of REDD+, risks made 
all the more significant given the dollar amounts committed and expected. Despite this high risk, LICOCO notes that the anti-corruption tools are not finalized. The responsibility rests on the program structure to design their own anti-corruption system. Transparency International defines corruption in REDD+ as "state capture, through grand corruption or political corruption, in which powerful groups or individuals seek to influence the design of a country's REDD + national framework for the benefit of their private interests." ${ }^{21}$

\subsection{Land conflicts: Between land duality and pressures on the land}

\section{Conflict typologies in the Mai-Ndombe Province}

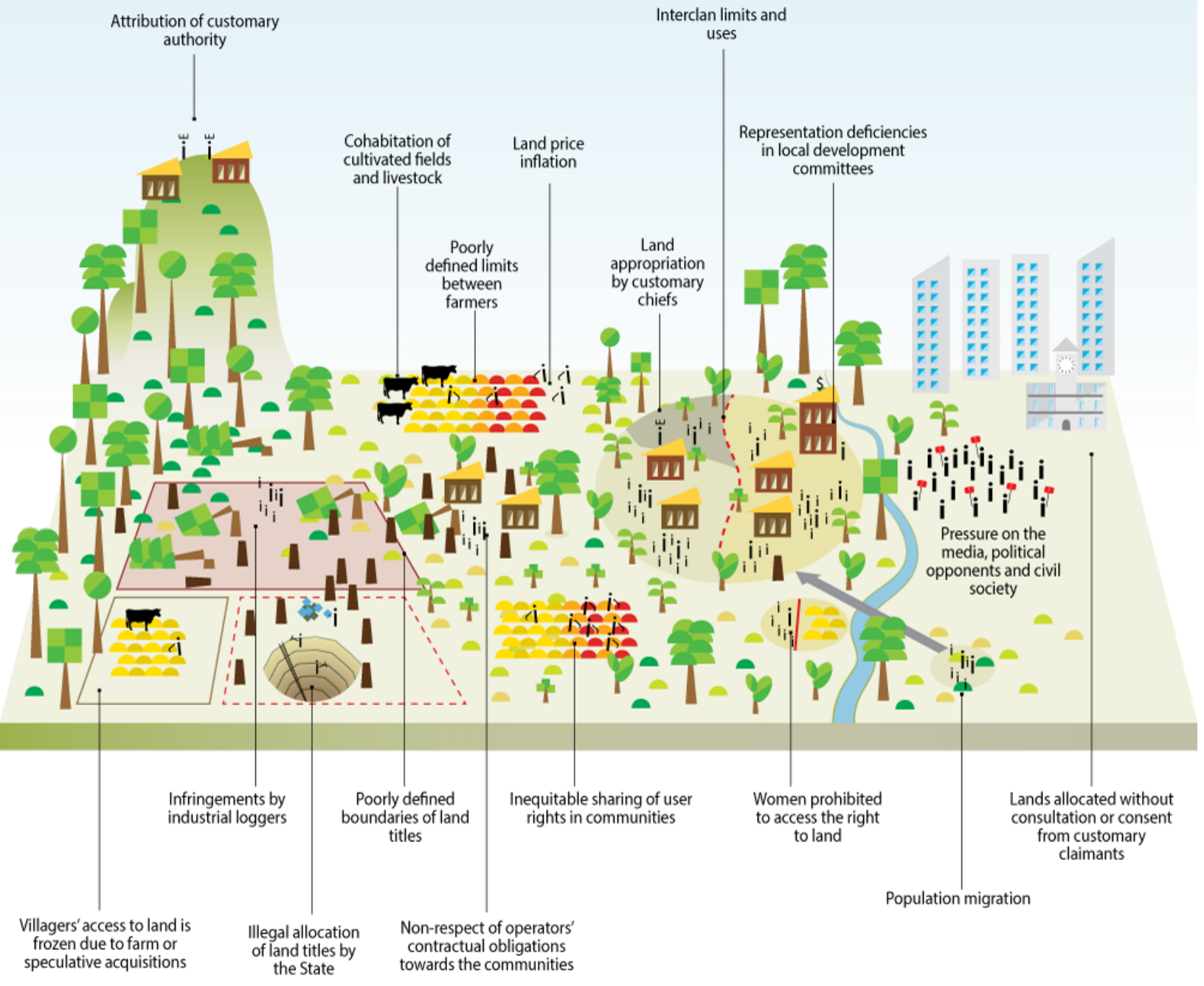




\section{A relatively quiet province in a country still shaken by many violent conflicts}

The Heidelberg Institute Conflict Barometer ranks the DRC at 4 on a scale of 5; that is, in a state of "limited war."22 The Democratic Republic of the Congo's recent history is marked by two civil wars (the first Congo war in 1996-1997 and the second Congo war in 1998-2003), and many conflicts are still active in several Eastern provinces (the Kivu war, conflicts between armed Mai-Mai groups as well as between Pygmies and Bantu in Katanga, armed groups active in Kasai, ethnic conflicts in Ituri, etc.). To date, the main conflict at the national level involves opposition groups and the government, following the latter's refusal to relinquish power. However, it should be noted that at the subnational level, the province of Mai-Ndombe is classified at level 1 by the Institute, which is to say "without violent conflict." Despite localized episodes, Mai-Ndombe remains spared from the abuses of armed groups and the Congolese army, and recent uprisings against the government have not affected the province.

\section{Migration processes and increased pressure on land}

In the face of increased pressure on the land, land ownership dynamics are changing in MaiNdombe. The province has between 1.5 and 1.8 million inhabitants, ${ }^{23}$ with a low population density, ranging from 73.1 inhabitants per square kilometer in the Yumbi territory to 5.4 inhabitants per square kilometer in Oshwe. Despite the province's size and its low population density, competition for access to land is a real challenge, especially in the south of the province closer to Kinshasa. A recent study conducted on the Batéké plateaus identified a migratory flow from Kinshasa to the province, mainly due to the unemployment rate in the capital. ${ }^{24}$ In search of work and attracted by the location's agricultural activity, people from outside the province flock to the plateau to sell their labor or rent forest plots from customary authorities. This new phenomenon of "landless peasants" is a cause of many conflicts in the province, as conflicts result where ownership is not clarified between customary managers and land users for agroforestry projects, resulting in slowdowns or even barriers to tree planting.

\section{Land confusion and overlapping rights cause many conflicts}

In a field study conducted by RRI in Mai-Ndombe in August 2016, community representatives identified the land situation as a major source of conflict. ${ }^{25}$ Communities most frequently identify the following land tenure conflicts: inter-community conflicts over land boundaries and customary powers, conflicts between communities and the state around decisions made by state land management or land allocation agencies without consultation or consent of customary rights holders, as well as illegal land titling by the state. ${ }^{26}$ There are also conflicts between pastoralists and farmers, mainly in the south of the province. Land administrators reportedly spend about 50 percent of their time working on land dispute arbitration. As analyzed by the Land Use Reform Program, ${ }^{27}$ the DRC does not control its geographic area. Although it is an indispensable element for the establishment and success of REDD+, land use planning has neither an appropriate legal, regulatory, or institutional framework in the Democratic Republic of the Congo, nor a consultative system between the different sectoral policies. This also holds in Mai-Ndombe, where land allocations take place outside a provincial intersectoral planning framework and give rise, on the one hand, to a complex land situation threatened by overlapping rights and uses and, on the other hand, to difficulties in tackling long-term deforestation in projects. 


\section{Customary dynamics are also sources of land conflicts}

The land chief, considered by custom to be the guardian of territories, manages the lands on behalf of and for the benefit of the community. He is therefore responsible for allocating land use and negotiating its price, which depends mainly on its proximity to the cities. ${ }^{28}$ Many communities also manage their land in a clan rotation system of their own. But customary dynamics are sometimes at the root of conflicts: conflicts regarding use between different clans, inequitable distribution of usage rights within communities, or land chiefs appropriating the land for gainful personal use. In the latter case, the land chiefs distribute, sell, or lease the land, allocating land in an anarchic manner without taking the communities' interest into account. Large breeding concessions, mainly supplying Kinshasa, deprive villages of land, while the repeated costs of obtaining concessions, arbitrarily set by these leaders, penalize small farms to the benefit of larger farmers capable of paying. Conflicts related to these dynamics are often settled by peer courts led by customary chiefs, as state justice is considered too expensive, burdensome, and inappropriate. The use of customary law, generally well observed by land chiefs, usually resolves conflicts of use within or between communities. ${ }^{29}$

\section{A history of conflict between concessions, conservation, and communities}

Land pressure is particularly strong in Mai-Ndombe, where the price of land is constantly rising. Faced with this phenomenon, the speculative conversion of land into capital assets is already taking place. Agricultural concessions are being acquired and not exploited, while communities, who sometimes protest violently, are forbidden from accessing them. ${ }^{30}$ Granting concessions without communities' free, prior, and informed consent; lack of respect for smallholders' contractual commitments; and communities calling into question the agreements negotiated without their free, prior, and informed consent are among the most frequent causes of conflict. Those which occurred in the SOGENAC ${ }^{31}$ breeding concession, the WWC ${ }^{32}$ conservation area, the SODEFOR ${ }^{33}$ logging concessions, and the Mpole and $\mathrm{Mpaha}^{34}$ lands have been widely documented. The conservation and establishment of protected areas is often a source of conflict, and even of violent evictions and clashes. In the Tumba Lediima Nature Reserve, relations between protected area managers and communities are highly conflictual, as evidenced by reports of abuses and human rights violations by eco-guards, as well as communities' perception that the restrictions imposed on them ${ }^{35}$ have a negative impact on their livelihoods. In each of these cases, the lack of prior consideration for communities' pre-existing customary rights and the allocation of areas where local communities conduct their activities (hunting, fishing, agriculture, gathering) give rise to conflict situations in the course of resource use between the concession holder or the protected area manager and the communities.

\subsection{Carbon rights, land rights, and securing community rights: $A$ complex and little-known legal framework}

\section{Land expertise largely delegated to the province}

In the 2006 Constitution, the province obtained a series of exclusive powers, some of them pertaining to land, ${ }^{36}$ while also gaining powers concurrent with those of the central government. 
Where exclusivity on land or land-related matters is concerned, the following precedents should be noted: (i) the provincial development plan, (ii) the issuance and preservation of property titles, (iii) the property tax, (iv) the development of agricultural, mining, and forestry programs of provincial interest, $(v)$ and the enforcement of national legislation on the urban and rural habitat. The provinces can also legislate on land and mining rights, land development, and the forest and water regimes, in accordance with national legislation and regulations. ${ }^{37}$ With regard to forests, there are plans to set up a provincial forest advisory council which will advise on decision-making. Unfortunately, this advisory council is not yet operational in Mai-Ndombe. The clarification of land tenure and the identification of rights holders to land and carbon (these rights can be held by different individuals or clans) may also be considered as a matter for the Mai-Ndombe provincial administration. However, given that the administration is in its inception and remains fragile, this power will require close attention and continuous capacity improvement to ensure effective and transparent management of carbon rights.

\section{Many concessions have already beem allocated to farmers on a non-regular basis, with negative impacts on the rights of local communities}

In Mai-Ndombe, protected areas and logging, livestock, and conservation concessions cover 30 percent of the province's total area. Industrial and conservation forest concessions alone account for more than one-third of the province's forest area, 69.5 percent of which is owned by a single forestry company, SODEFOR. ${ }^{38}$ All these concessions are superimposed and form a spatial unit that is extremely complex to administer: confusions abound both geographically (superposition of securities, no consultation with or compensation for local rights holders) and temporally (different temporalities of concessions according to their type), as well as in terms of regulations (forest code, land law, agricultural, mining, planning decree, etc.). In addition, in its report on the land governance assessment framework, the World Bank states that the rights of local communities do not enjoy sufficient legal guarantees to safeguard them from damages (losses or restrictions) that could result from the State's allocation processes, particularly in the REDD+ process. ${ }^{39}$ The ongoing land reform, which is one of the CAFI-supported REDD+ initiatives implemented in Mai-Ndombe, provides an opportunity to solve these issues. 


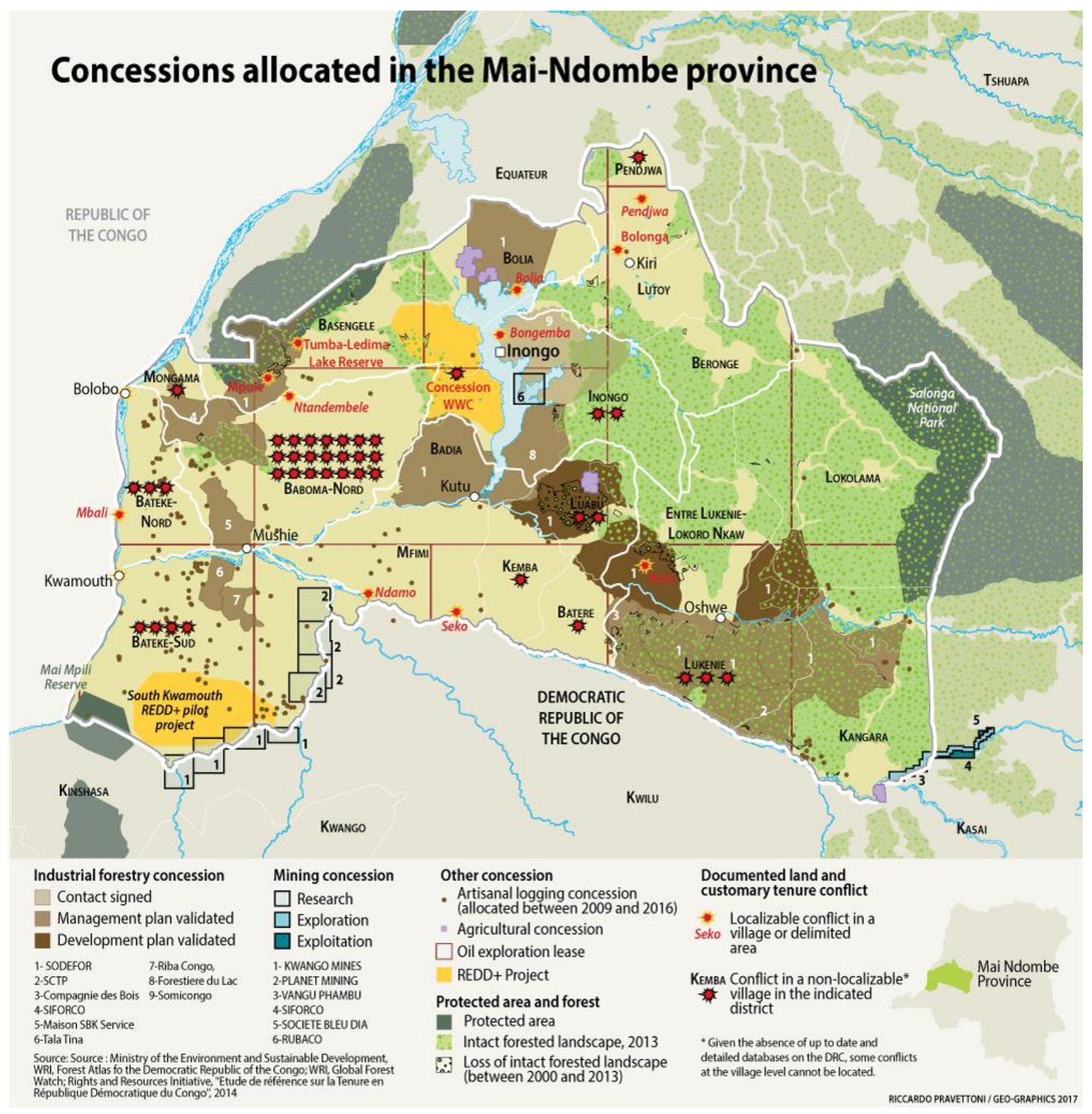

The difficult cohabitation of a state-based land system and customary land management

The 2006 Constitution recognizes local communities' land rights and guarantees the right to individual or collective property acquired in accordance with the law or custom. It also recognizes customary authority. ${ }^{40}$ In the absence of a legal mechanism to secure customary rights held by local communities, these communities and their members generally use several types of documents to justify their rights to land in peri-urban areas (parcel registration sheet, land cession deed, use permit, etc.). However, these documents are not legally-recognized land titles. According to customary law, land is managed locally by the community, most often through a rotating clan system. In rural areas where the administration is relatively absent, land is often acquired by mere declaration to the customary authority, with neighbors acting as witnesses, and without any 
document attesting to the transfer of rights. Moreover, while the customary tenure principle requires that all sales and disposals of land be made or approved by the land chief, in customary practice land is sometimes sold without the chief being informed of it. In this case, the customary vendors are the direct rights holders, which vary according to whether the system is patrilineal (a majority in the district of Mai-Ndombe) or matrilineal (a majority in the Plateau district). In the latter, it is mostly the uncles or the maternal nephews who become the rights holders. This customary land system, unrecognized and complex, should be studied in order to be better understood. No such thorough study has been done to date. The administration thus fails to contend with the realities of certain practices considered legitimate within communities.

\section{Community forestry's opportunity and its lack of implementation}

The law governing land in the $\mathrm{DRC}^{41}$ mostly disregards the interests and rights of local communities and Indigenous Peoples, ${ }^{42}$ despite the guarantees offered by the Constitution. Land security remains inaccessible to communities, given the lack of access to state-owned land services, the limited financial resources available to them, and the procedures' complexity. However, in the case of forests, the Forest Code establishes the community forestry process, ${ }^{43}$ which offers considerable potential for securing the land and forest rights of communities through local community forest concessions

However, in the case of forests, the Forest Code establishes the community forestry process, which offers considerable potential for securing the land and forest rights of communities through local community forest concessions. (CFCLs). CFCLs were established in 2002 by the forest code and operationalized by a decree and an order in $2014 .{ }^{44}$ They allow local communities and Indigenous Peoples to acquire a definitive, legal community tenure right to a forest area up to 50,000 hectares. However, of the 65,308 hectares requested by 13 local communities in the territories of Mushie and Bolobo, with support from the NGOs Mbou Mon Tour and WWF, only 300 hectares were granted to each community by the provincial governor, for a total of 3,900 hectares. Communities that felt aggrieved said they wanted to negotiate a reparation with the provincial authority. Other approaches are being taken by communities in Oshwe territory to acquire CFCLs. The provincial Minister of the Environment has proposed that "Decree 14 and Order 025 be simplified in order to allow communities and local administrations to know what procedure to follow in order to grant more of the CFCLs likely to boost grassroots development in the future."45

\section{Sharecropping as a means to access land}

The main ways to access arable plots remain purchase, donation, and inheritance, as well as renting and sharecropping. In community forests, under customary tradition, any member of the community has the right to cut down trees for household use without requesting permission. However, migrants and marginalized populations (such as Pygmies) must request authorization to use any piece of land. The most common alternative is access to land through rental (a sum is paid regularly to the land chief) or sharecropping (part of the harvest is paid to the land chief). ${ }^{46}$ Sharecropping thus remains Pygmies' most common way of accessing land. ${ }^{47}$ The increase in migrants over the last 15 years has led to increasing population pressure and a decrease in soil quality. In response, the conditions to access land are more demanding: up to 50 percent of the 
crops produced by sharecroppers must be given to the rights holder. These working conditions are pushing sharecroppers to cut more forest area, bringing the rate of forest cover degradation to 15 percent on the Batéké plateaus between 2000 and 2015 (more than double the national average). Similarly, civil society observers in Inongo claim to see migrants arriving from the south of the province (Boko, Kutu, Mute) seeking new lands to cultivate.

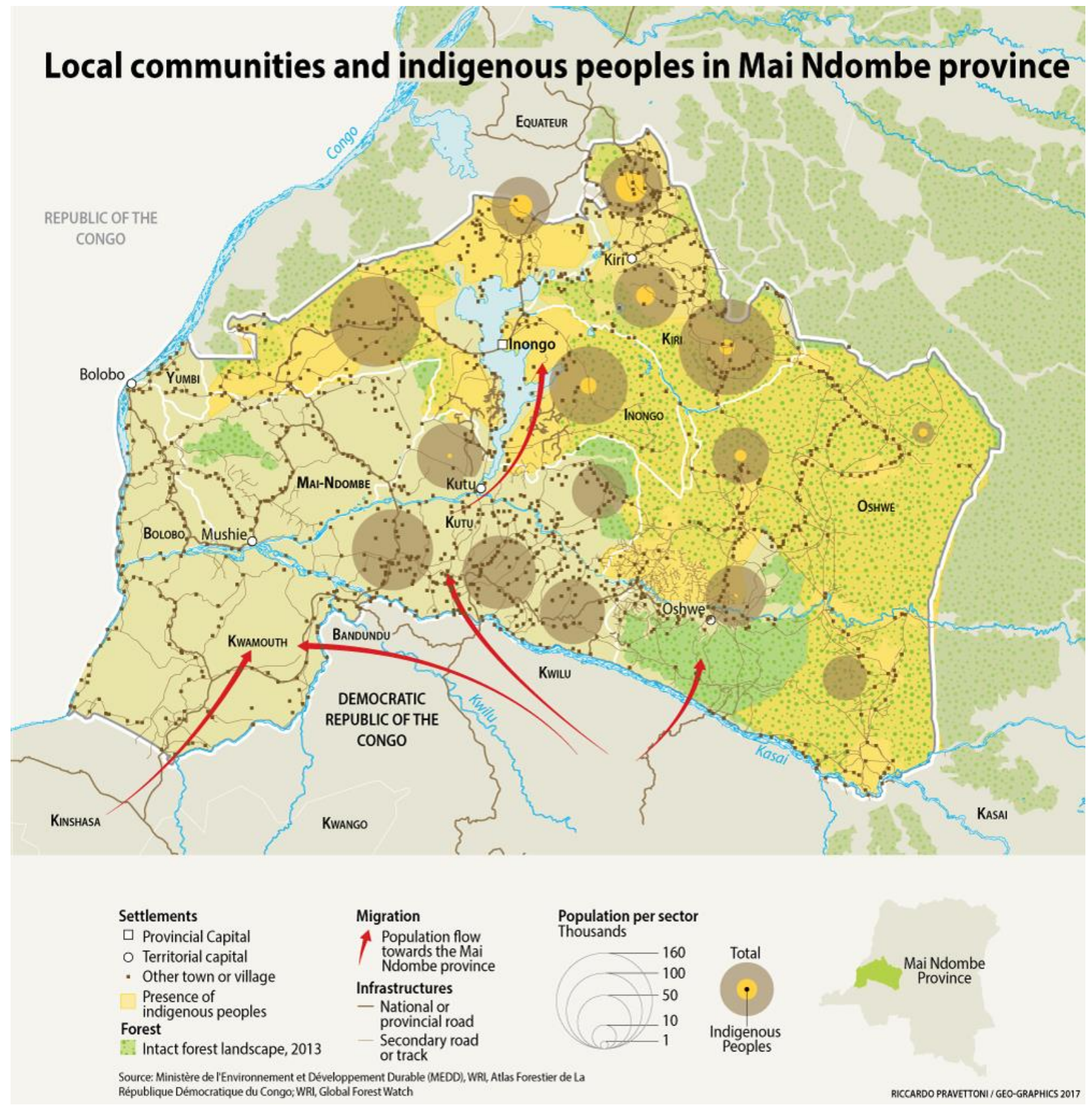




\subsection{The rights of Pygmy Indigenous Peoples: Recognized but flouted}

\section{Legal recognition through international treaties}

Pygmies represent $600,000-700,000$ people, spread throughout the country. ${ }^{48}$ In the province, Indigenous Peoples are present in only three territories: Inongo (21,047 people and 105 Pygmy Batwas or mixed Batwa / Bantu villages), Kiri (38,326 people and 153 Pygmy Batwa or mixed villages), and Oshwe (13,999 people and 25 registered Pygmy ${ }^{49}$ or mixed Pygmy villages), for a total of about 73,000 Pygmy Batwa and Moones. There is also a small diaspora of 100-200 Pygmy households in the territory of Kutu, which has the highest population density. They are grouped together in Nioki and Bokoro and sell their labor power there. Since they do not come from the territory, they lack customary rights. ${ }^{50}$ While the Constitution of the DRC affirms that no distinction should be made between Congolese citizens, ${ }^{51}$ it also gives international treaties and agreements supremacy over national laws. ${ }^{52}$ The rights of Indigenous Peoples are thus recognized through the conventions ratified by the DRC, ${ }^{53}$ such as the International Convention on the Elimination of All Forms of Racial Discrimination, but as noted by the APD, ${ }^{54}$ a specific law and more precise protection is needed at the national level.

\section{A group that is extremely vulnerable and discriminated against}

Though Pygmy villages, like any locality, are recognized as basic administrative entities by the state, those governed by Pygmy chiefs are not recognized by the land chieftain or the Bantu territory. With the exception of a few Pygmy villages that also hold the land chieftainship, ${ }^{55}$ their land rights are recognized neither by law nor by most local customs, despite numerous requests to be recognized and formalized. The Indigenous Peoples Plan reports that more than 70 percent of respondents deplore that their traditional forests are legally owned by the Bantu and that 90 percent of them have to pay a tribute to the Bantu chiefs to access the land. This lack of recognition weakens their bargaining power and their participation in decision-making processes impacting their lands. Their participation is made weaker as the Pygmies declare that they are seldom or never admitted to the community's representative structures. This absence often excludes them from negotiations on the dividends of natural resource exploitation and the monitoring of social clauses included in the forest concessions' terms of reference. This situation is part of a highly discriminatory local context, though the nature of the discrimination varies from one community to another: forced labor; looting the spoils of their hunt and harvest; physical torture; arbitrary arrests by police and other state agents; lower wages often paid in alcohol and hemp; and the ban on Bantu to shake hands, drink, or eat with an indigenous community member. ${ }^{56}$ This particularly high level of discrimination is reinforced by difficulties in access to education and justice.

\subsection{Strong discrimination against rural and indigenous women}

\section{Enhanced legal protection: equal access to property}

The Democratic Republic of the Congo recognizes equal rights to property between men and women. ${ }^{57}$ Article 14 of the Constitution guarantees parity between men and women, and the Gender 
Equality Act, promulgated in $2015,{ }^{58}$ provides a solid foundation by ruling that women must be fairly represented in all nominative and elective functions within national, provincial, and local institutions, including institutions supporting democracy. The country's economic development policies and programs must be developed and implemented with gender considerations in mind, and must ensure everyone has equal access to resources and their benefits. Finally, the State must take measures to eliminate any practices that are detrimental to women's rights as pertains to access to property, management, administration, enjoyment, and disposal of property. In this sense, the DRC recognizes widows and daughters have equal inheritance rights, although it does not recognize these rights for unmarried women engaged in consensual unions. ${ }^{59}$ The Democratic Republic of the Congo has also ratified the Convention on the Elimination of All Forms of Discrimination against Women (CEDAW), the International Convention on Civil and Political Rights, and the International Convention on Economic, Social and Cultural Rights that also provide tools for women's rights advocacy by asking signatory states to eliminate all forms of discrimination against rural women and to ensure their equitable participation "in all community activities." 60 Similarly, the UN Declaration on the Rights of Indigenous Peoples, ratified by the DRC, encourages states to ensure that indigenous women enjoy "full protection and guarantees against all forms of violence and discrimination," and to take specific measures to protect "the particular rights and needs of indigenous women and enable their social and economic advancement." ${ }^{61}$

\section{Rural and indigenous women: the groups experiencing the most discrimination}

Notwithstanding these provisions, community land tenure in DRC, that is, community forestry, does not include any specific measure to guarantee women's rights and to propose a positive interpretation of customary law in their favor. This lack of concrete action within the Congolese land tenure regime limits the ability of the state to combat discriminatory practices and prevents women from improving their access to, control over, and use of community forests and lands. When ignoring gender, a community-based land tenure regime such as a CFCL can even undermine the positive community norms that exist in some indigenous communities. ${ }^{62}$ It does not allow just practices of the rights of rural and indigenous women to inheritance, community representation, community governance, or conflict resolution. Discrepancies between indigenous laws and practices thus remain a major obstacle to securing women's land tenure. Indigenous Peoples' organizations note that indigenous women are the social category experiencing the most discrimination. The infant and maternal mortality rate is very high, due to lack of access to health care, and Pygmy women are victims of repeated rapes, a practice common in some Bantu communities towards indigenous women. Treaty implementation remains weak, a fact that was strongly criticized by the Office of the United Nations High Commissioner for Human Rights during the universal periodic review conducted in 2014. ${ }^{63}$ CEDAW notably highlights discriminatory provisions against women in the family code. It also notes a worrying prevalence of violence against women throughout the country in the form of sexual violence, incest, harassment, domestic violence, and torture, and considers that the impunity of the guilty party is one of the sources of this violence.

\section{Women's extremely low rate of participation in public life}

This discrimination results in an extremely low rate of women's participation in public life and politics at the national, provincial, and local levels, including in decentralized regional bodies. This comes to light when projects and activities are organized. The situation is all the more precarious for 
rural women, who are disproportionately affected by illiteracy and the lack of adequate health services, education, economic opportunities, and social benefits. ${ }^{64}$ Men are still the majority in decision-making bodies in rural areas, where women have very low representation and seldom or never speak up. The inferiority complex and the weight of tradition (women cannot speak in front of men) remains difficult to overcome. The latest women's outreach missions in Mai-Ndombe also noted that when women are actively involved in management bodies, they only hold positions as treasurers, cashiers, or comptrollers, and are never in positions that require decision-making. ${ }^{65}$

\section{Lack of access to lands and key resources}

Women play a crucial role in agricultural activities: near villages, the savanna area reserved for agriculture and forest fields used for self-sustenance are exclusively exploited by women. They mainly cultivate groundnuts and cassava, while the men are in charge of the cash crops (mainly cassava and maize) to be sold in town. ${ }^{66}$ Yet, in the savanna zones of western Congo, women do not have financial autonomy and their role in the clan often corresponds to that of a farm worker. ${ }^{67}$ According to the widespread, discriminatory interpretation of customary law, which is a fluid framework that allows for various interpretations, women are not considered as rights holders and, as such, are not consulted on land issues by decision-making bodies. The traditional matrilineal tenure system itself states that kinship is given by the mother, not that the woman enjoys a larger role in the family. The claimants in the matrilineal household are the uncles or the maternal nephews. ${ }^{68}$ The potential of women to become rights holders in such a system, however, would benefit from research. In some territories, women hold the right of enjoyment on behalf of their families and could obtain it through inheritance, provided they have boy children. However, they are often prohibited from inheriting from their deceased parents or husbands and are thus left without land. Yet the Constitution itself, which recognizes customary law, prohibits such discriminatory practices by asking customary authorities to adhere to the Constitution and national laws, ${ }^{69}$ including the law on parity. Some more educated women claim their rights in court and can now invoke the law on parity, but this is rare. Most of the time, conflicts are resolved by family councils or land chiefs who rely on a discriminatory interpretation which disadvantages women. ${ }^{70}$ 


\subsection{Difficult living conditions and low livelihoods of communities}

\section{An agricultural province with low food security}

Agriculture is practiced by 90 percent of households in Mai-Ndombe. It is the main source of cash income, followed by fishing, cattle breeding, hunting, and gathering. ${ }^{71}$ Indigenous Pygmy Peoples add agricultural wage-earning to these activities, albeit at very low prices. After becoming sedentary and given the diminishing amount of game, they also practice small livestock breeding, agriculture, and small amounts of trade in non-timber forest products. The BioCFplus survey notes an annual median income of US\$450. Since a Congolese household is composed of an average of five people, ${ }^{72}$ the median income per person in Mai-Ndombe is US $\$ 0.24$ per day per person, well below the poverty line. ${ }^{73}$ Mai-Ndombe has one of the highest rates of poverty in the country. ${ }^{74}$ However, food security varies within the province: ${ }^{75}$ in the Oshwe, Kiri, and Inongo territories, which are close to the forest and the lake, access to bushmeat and fish is regular, while inland savannah populations suffer from protein deficiencies. Despite surplus food production in the province, temporary shortages are reported for cassava, which is the staple food. Its production, as well as the production of maize, rice, plantain, beans, and peanuts, is in fact mainly oriented towards market sales. Food supplementation programs were therefore set up in the savannah areas to cope with young children's nutrition problems.

\section{Economic dependence on the Kinshasa market}

The market in Kinshasa, which is economically fragile, cannot tolerate price increases, such that any decline in this market has serious consequences on the people of Mai-Ndombe. The marketing of agricultural products does not benefit households to their full potential, mainly for geographical and infrastructural reasons. While the price of cassava and corn per ton are in fact about US\$156 and US $\$ 144$ respectively, the income lost during producers' journey does not produce a net profit: the men transport the goods to Kinshasa, consuming much of the profits from their sale on the spot and during their return to their villages, bringing home only a small part of their income. ${ }^{76}$ This dependence and the fragility of this production system make the province's revenues very insecure. It also explains the population's inclination toward the production and marketing of charcoal. Charcoal can be produced quickly, is non-perishable, and is more lucrative: in one month, a group of three workers can produce up to 300 bags of coal, generating US $\$ 1,200$ (US\$4 per bag). As the market is extremely demanding, these bags are bought by traders at the edge of the rivers and transported by boat to be resold from US\$15 to US\$17 per bag on the Kinshasa market.

\section{Precarious living conditions and low access to education}

The living conditions in the province are precarious: access to water is limited, housing is precarious, and public health services are dependent on international aid, obsolete, and prohibitively expensive for the poorest. None of the Pygmies interviewed in the Inongo territory have access to running water. Only 3 to 6 percent say they have access to health centers, due to lack of money, their distance from the centers, and the stigmatization they receive from health workers. ${ }^{77}$ They are thus more vulnerable to disease, and their life expectancy is generally lower than that of Bantu populations. The dispossession of Indigenous Peoples from their ancestral lands amplifies this phenomenon, as restricted access to their lands deprives them of their traditional pharmacopoeia. Access to education also remains a challenge, with primary school enrollment reaching only 72 
percent for boys and 61 percent for girls. ${ }^{78}$ This rate is even lower for Indigenous Peoples (only 30 percent of children attend primary school ${ }^{79}$ ), as they lack financial means and require their children's help in agricultural and forestry work. Generalized illiteracy limits the participation of this vulnerable population in many decision-making processes.

\subsection{Limited community participation in decision-making processes}

\section{Free, Prior, and Informed Consent (FPIC), a constitutional legal principle}

Free, Prior, and Informed Consent (FPIC) is a collective right based on human rights and is part of the right to self-determination, land, natural resources, culture, freedom, and non-discrimination. Indigenous Peoples' rights are protected by FPIC, which gives all indigenous and local communities the right to participate in decisions that may affect their lands and resources, and to give or withhold their consent. This consent must be "free," that is to say without coercion, intimidation, or manipulation; "informed," meaning that communities have all the necessary information such as the nature, scale, scope, evolution, duration, purpose, location, impacts, implementation conditions, procedures, participants, and reversibility of proposed activities or projects; and "prior," that is to say, it must be done before the authorization or start of any activity, in the time frame needed by the community to find a consensus. ${ }^{80}$ The concept of "process" is also important, since FPIC is not a single given agreement. Rather, it must be a participatory approach lasting through the duration of the project, and in which communities are free to withdraw their consent even after activities have started. ${ }^{81}$ This principle is integrated into the legal arsenal of the DRC through its ratification of the African Charter on Human and Peoples' Rights and that document's jurisprudence pertaining to the right to development. ${ }^{82}$ On the basis of the Constitution, as well as of international standards ratified by the DRC, a number of national and international NGOs (WWF, Cl, FPP, NRN) have developed their own FPIC implementation guides, which apply both to Indigenous Peoples and to local communities likely to be affected by REDD+ initiatives. In December 2015, the national REDD+ coordinating body established national FPIC standards, ${ }^{83}$ as well as a methodological guide for FPIC which is awaiting validation. UNDP, as part of its support for REDD, is also developing a consultation guide, which has not yet been finalized. However, there are still shortcomings regarding the participation of civil society and communities, particularly with regard to REDD+. These are analyzed later in this document.

\section{Structural, legal, and financial challenges to the application of FPIC}

Due to a lack of access to information, communities cannot fully participate in the various decision-making processes. While geographical isolation and educational disparities are major challenges to local organizations' and communities' access to information, government's irregular presence in remote areas and weak laws governing land and resources are also obstacles to information transfer to citizens. The guarantees of the land, agricultural, and forestry codes, in the form of vacancy surveys or consultations, remain insufficient. Of the sums invested in the REDD+ preparation phase,

Of the sums invested in the REDD+ preparation phase, funds for consultation with and participation of DRC forest communities have remained extremely low, despite the fact that their rights and livelihoods will be the most affected. 
funds for consultation with and participation of DRC forest communities have remained extremely low, despite the fact that their rights and livelihoods will be the most affected. ${ }^{84}$ In this context, a dialogue on the topic of forests was organized by FPP in 2012 to explore the practical application of FPIC by government agencies, commercial enterprises, and local communities. The FPIC guide, produced by the CN-REDD in 2014, also explores these topics. Unfortunately, the results of this work have not been tested in the field yet and this legal principle is not yet operationalized. 


\section{Are the cumulative impacts of REDD+ initiatives under control?}

The national and provincial REDD+ implementation context presented in Chapter 2 lays the groundwork to grasp the importance of the facts and observations pertaining to REDD+ initiatives in Mai-Ndombe that will be presented in this section. The cumulative impacts of REDD+ initiatives are analyzed by taking contextual risks and the social, economic, political, environmental, and legal situation of the province into account. These risks should be known, integrated into planning, and controlled in a coordinated way in order to ensure the success of REDD+ initiatives. This analysis explores these initiatives' ability to control their impacts in order to fulfill the two REDD+ objectives: reduced deforestation and "co-development benefits" for the Congolese population. ${ }^{85}$

\subsection{Governance: A fragile and incomplete architecture}

\section{A lack of national REDD+ governance structure undermines state ownership of REDD+ and violates the Cancun safeguards}

The national governance structure of REDD+, as legally defined, ${ }^{86}$ is not operational. The national REDD+ committee, an advisory and decision-making body involving all stakeholders, including civil society, no longer meets and has only existed on paper since 2012. The interministerial committee and the scientific council, the planning and technical analysis bodies, do not appear in any project document or meeting report. An assessment of the National REDD+ Coordination, the central body, concluded it lacked the necessary technical resources and functional resilience, and did not demonstrate sufficient political commitment. ${ }^{87}$ Rather than strengthening it, the World Bank stopped funding it in June 2017, citing the closing of ERP-D and the REDD+ preparatory phase. This decision does not take into account the crucial role of The interministerial committee and the scientific council, the planning and technical analysis bodies, do not appear in any project document or meeting report. An assessment of the National REDD+ Coordination, the central body, concluded it lacked the necessary technical resources and functional resilience, and did not demonstrate sufficient political commitment. national coordination beyond the ERP, as evidenced by its creation decree which confers on it the sovereign mission of the day-to-day management of the entire REDD+ process in DRC, from the preparation phase to the distribution of results-based payments, through the investment phase. Current projects, such as those aiming to complete governance tools, were halted abruptly without a finalization plan being put in place. In the absence of CN-REDD, FONAREDD seems to be the only REDD+ interlocutor at the national level. However, created by the international institutions as an independent fiduciary body, it aims to centralize REDD+ funds and ensure the coordination of CAFI funding, not to act as a substitute for the state's program coordination body. This lack of a transparent and effective national coordination structure is in direct opposition to the second Cancun safeguards. ${ }^{88}$ 
The lack of a provincial governance structure for REDD+ and inefficient decentralization undermine the coordination and on-the-ground monitoring of REDD+ initiatives

The province, suffering from inefficient decentralization, lacks the means, channels of communication, and, notleast, a governmental driving force. The provincial REDD+ focal point, mandated in the REDD ${ }^{89}$ governance body ordinance, has also disappeared due to lack of funding. The provincial government has not yet branched out into decentralized territorial entities, and its links with customary power are not defined in any REDD+ project. The provincial government's ability to monitor projects in the field is therefore currently non-existent. While the provincial government should be a pillar of REDD+ implementation and is considered the ERP's project manager, ${ }^{90}$ its weaknesses demonstrate its inability to ensure coordination among donors, local authorities, customary authorities, project leaders, implementing bodies, and local implementing agencies or beyond a given program, delegating this coordination to the national level. However, the lack of national REDD+ coordination and the weak institutional coordination arrangements at the national and provincial levels are compounding the provincial government's weak capacity. This represents one of the main risks for the implementation of REDD+ in Mai-Ndombe.

\section{The triple role of the ERP management unit (PMU) involves conflicts of interest hindering its mission}

The CAFI Governance Program provides for the establishment of a Provincial Program Management Unit (PMU). However, in a context where both national and provincial state coordination are lacking, its connections with projects and the government are not clearly defined. In particular, the PMU would be responsible, according to the governance program's project, for coordinating the project and its related initiatives, marketing the carbon credits generated by these projects to potential buyers, and ensuring the implementation of safeguards by these projects. This triple role of management, marketing, and sanctioning leaves room for multiple conflicts of interest: the same entity cannot be judge and stakeholder. Its ability to sanction projects that it manages and promotes will be limited in nature. Whether safeguards are properly implemented in such a system is therefore doubtful.

The absence of several REDD+ governance tools stops projects from effectively monitoring their impacts and controlling their risks

Although the REDD+ preparatory phase is considered complete, the governance tools that should have been developed have not yet been validated. The Recourse and Feedback Mechanism, the National REDD+ Benefit Sharing Plan, the Safeguards Information System, ${ }^{91}$ the REDD+ Project Approval Decree, the National REDD+ Registry, the Independent Observation Tools, ${ }^{92}$ as well as the adaptation of these tools based on the study of land and customary rights at the project level are still non-existent. The REDD+ benefit-sharing plan in the Mai-Ndombe province, developed by the World Bank, is still debated and its "advanced" version has not yet been released. Under these conditions, the management and monitoring of good project governance cannot be carried out. The US\$9 million CAFI-funded "Governance" program, implemented by the World Bank, is designed to address these shortcomings by developing the Recourse and Feedback Mechanism, the National REDD+ Registry, and the information and safeguards system. However, this program is not yet approved. 


\section{Safeguarding instruments are not functional and do not apply consistently to all projects}

The BIP produced a set of safeguards applicable to the PIREDD Plateau, updated in April 2017, to incorporate an "extension to the Mai-Ndombe PIREDD intervention area." They contain a safeguard document specifically targeting the situation of Indigenous Peoples, to which the ERP and CAFI refer. REDD+ standards have been adopted by the CN-REDD. These documents should be complemented by the framework of national guidelines on Free, Prior and Informed Consent (FPIC) in the context of REDD+ in the Democratic Republic of the Congo, initiated since 2014 but never finalized. CN-REDD now being absent, this finalization, as well as the implementation of these tools, remains unresolved. A stakeholder consultation guide is also being developed by the UNDP but has not yet been made public. The legal validity of these documents, their applicability, as well as their connection, has yet to be defined. These documents do not have an operational component and do not include cost estimates for their implementation. National and international civil society ${ }^{93}$ point to inconsistencies and the unclear roles and responsibilities of institutions in their implementation. In addition, monitoring and evaluation processes rely on three currently non-operational bodies: the National REDD Commission, an entity that has not been meeting for years; an "independent monitoring tool," which was never developed; and the Moabi platform, unfunded at the moment. Finally, the safeguards vary from project to project and are therefore not applicable to all projects, as described in the MaiNdombe REDD+ Summary Table (Figure 3). For instance, those from the private sector with "a REDD+ focus" depend on their own donor's safeguards, which can themselves change (the NovacelSouth-Kwamouth project complied with the African Development Bank's safeguard policies until 2016, and now complies with the World Bank, which has taken over the project under the BIP). Others, such as SOFORCO, depend on none until the project is certified. Since this set of safeguards does not apply uniformly, there is a risk of inconsistencies and unmitigated impacts across the province and across all initiatives. In addition, as these safeguards are not in effect, project implementation with a real and coordinated mitigation of the cumulative risks they pose to the population cannot be ensured.

\section{Independent observation is recognized as an essential tool, but is neither supported nor mandated}

The REDD+ certification organizations audits, ${ }^{94}$ which are conducted very infrequently, are not sufficient to properly monitor the evolution of projects and their impacts on deforestation and local communities. An independent monitoring mechanism is therefore planned at the national and provincial levels to impartially observe and report on issues in the field and the implementation of commitments made by REDD+ actors. The ERP thus refers to the Moabi platform and the National Observatory Organization for Forest Governance as potential independent observers, but also as tools to support the Monitoring, Reporting, and Verification System (MRV) and recourse and feedback mechanism (MRR). However, it does so without clarifying the links between them and the functioning and accessibility of these tools to the communities. Despite the role they are assigned in 
this document, to date, these organizations have not received an independent observation mandate or developed an approved methodology. The EU Citizens Voice for Change (CV4C) project, launched in April 2017 to train and involve non-state actors in forest governance, could contribute to the formation of this international organization. The sustainable forest management program, proposed by AFD, encourages this international organization and also provides support to the Observatoire de la gouvernance forestière (Forest Governance Observatory, or OGF). Here, the question however arises of the independence of an observer who would be financed by project promoters, and of its ability to effectively judge the good governance of the latter.

\section{The risk of corruption increases due to the structure and accumulation of REDD+ initiatives}

Both the lack of identification of customary forest owners in current initiatives and the delay of land reform illustrate the risk of REDD+ benefits being captured by the most powerful groups. The absence of a national land use planning policy at the national level and its transfer to the PIREDD level constitute an increased risk of corruption, which is not identified in the project documents. Given the financial stakes, each local development plan runs the risk of illegal influence from logging companies, project promoters, and agribusiness operators so that the land they own is included in or excluded from REDD+ programs. ${ }^{95}$ Before considering any financial support to the ERP, civil society calls for the establishment of transparent recruitment for the management of REDD+ programs, which are undermined by political patronage, and a transparent system of licensing and concession contracts. ${ }^{96} \mathrm{CAFI}$ addresses the risk of corruption in the management of program funds through the creation of FONAREDD, a fiduciary management body separate from the government, and by requiring a direct implementation modality ${ }^{97}$ in each of its programs. This modality dispossesses the local implementing agencies of part of the budget management of the implemented programs. The numerous programs to strengthen state authorities, notably in the PIREDD and the CARPE, also aim to reduce corruption at the national level. The national reforms initiated and the ongoing review of the REDD+ approval decree, which allow communities to gain project leader status, also confirm that consideration is taken to fight against corruption in the context of CAFI.

\subsection{Conflict mitigation: undervaluation and threat to REDD+ outcomes}

\section{The prospect of REDD+ benefits increases land predation and therefore the risk of land conflicts}

The existence of land conflicts is partly seen as the result of poor structural governance of land, operating in an outdated legal and institutional framework. ${ }^{98}$ In this context--and this is the goal of land reform--REDD+ projects impacting this land governance should necessarily be done in an improved structure. However, to date, many initiatives are already active, without this structure having been addressed. The addition of REDD+ projects to existing concessions amplifies the complexity of structural land governance and increases the risk of land conflicts. The improvements proposed by the projects (infrastructure, agro-forestry projects, etc.) and the prospect of REDD+ benefits also lead to an increase in the price of land, which further limits small producers' access to the benefit of industrialists who sometimes convert them into immovables for speculative purposes. 
In South Kwamouth, the mechanization of agriculture in the savannah attracted workers, increasing the migration phenomenon, while giving the savannah a monetary value it had never had; the traditional chiefs are now asking 50000 francs Congolese per hectare of savannah. ${ }^{99}$

\section{Land conflict risks are underestimated and neglected by REDD+ programs}

These pressures render both PIREDD projects high risk in terms of land conflicts and even population expulsion or displacement. The PIREDD Plateau Project Approval Document (PAD), however, ranks this program as "low risk" in terms of potential conflicts over access to land, conflicts over forest boundaries and use planning, or capture of funds by the elite to the detriment of local communities. The PIREDD Plateau, run by WWF, also includes community-based agroforestry activities and "integrated" food activities (mixing livestock and small-scale farming) without land clarification activities. Plantations are thus made on "empty spaces" belonging to communities that do not use them and that are cultivated by others, which can lead to land conflicts over who will reap the benefits when they materialize. In this context, the current initiatives, which neglect the issue of land tenure, do not make it possible to ensure that the various activities do not further weaken local communities and the most vulnerable social groups. In order to avoid these negative impacts, and in view of the history of conflicts between conservation and communities, a moratorium on the allocation of new conservation concessions should be considered, pending clarification of the land rights of communities and the establishment of an effective and accessible conflict management system.

\section{The story of conflicts between concessionaires and communities is repeated with REDD+ projects: the} cases of ERA / WWC and WWF

The WWC conservation concession, the only REDD+ project certified to this day, is at the heart of a fierce conflict with communities. Acquired by ERA in 2011 without, according to local civil society organizations, consultation with communities, ${ }^{100}$ it has not been the subject of land clarification, participatory mapping, public mediation workshops, or demarcation work to ascertain the limits of the concession. While it impacts communities' livelihoods by regulating, sometimes with the help of the police, slash-and-burn agriculture and logging, the compensation and community development mechanisms are not effective. The OGF, which has been monitoring the WWC grant closely to test an independent observation model for the application of safeguards, has identified a series of important failings: safeguards and specifications are not communicated to communities; lack of an environmental and social management plan incorporating specific safeguards' frameworks; lack of participatory zoning; lack of specific action towards vulnerable populations; lack of consideration of traditional cultural and technical specificities of forest management; lack of diversification of income-generating activities; lack of regular consultations; delays in the application of social clauses; lack of strengthening of local CLDs deemed to be weak; etc. ${ }^{101}$ In July 2017, a member of the community was again arrested and forcibly taken to the Inongo Police Station by WWC staff for "illegal logging" on the concession. Communities, dissatisfied, testified passionately about the negative impact of the concession on their traditional activities and their way of life. ${ }^{102}$ The payment system for environmental services set up under WWF's Carbon Map and Models project also suffers from conflicts with communities in the Bolobo territory over contracts signed between the project leader and WWF. Out of the four signed contracts, only one seems to work properly. An inability to understand the terms of payment for the savanna reforestation contract or diverging points of view 
between WWF and the local community was noted by the independent OGF observer. Claims relating to the payment of firebreaks have also been reported.

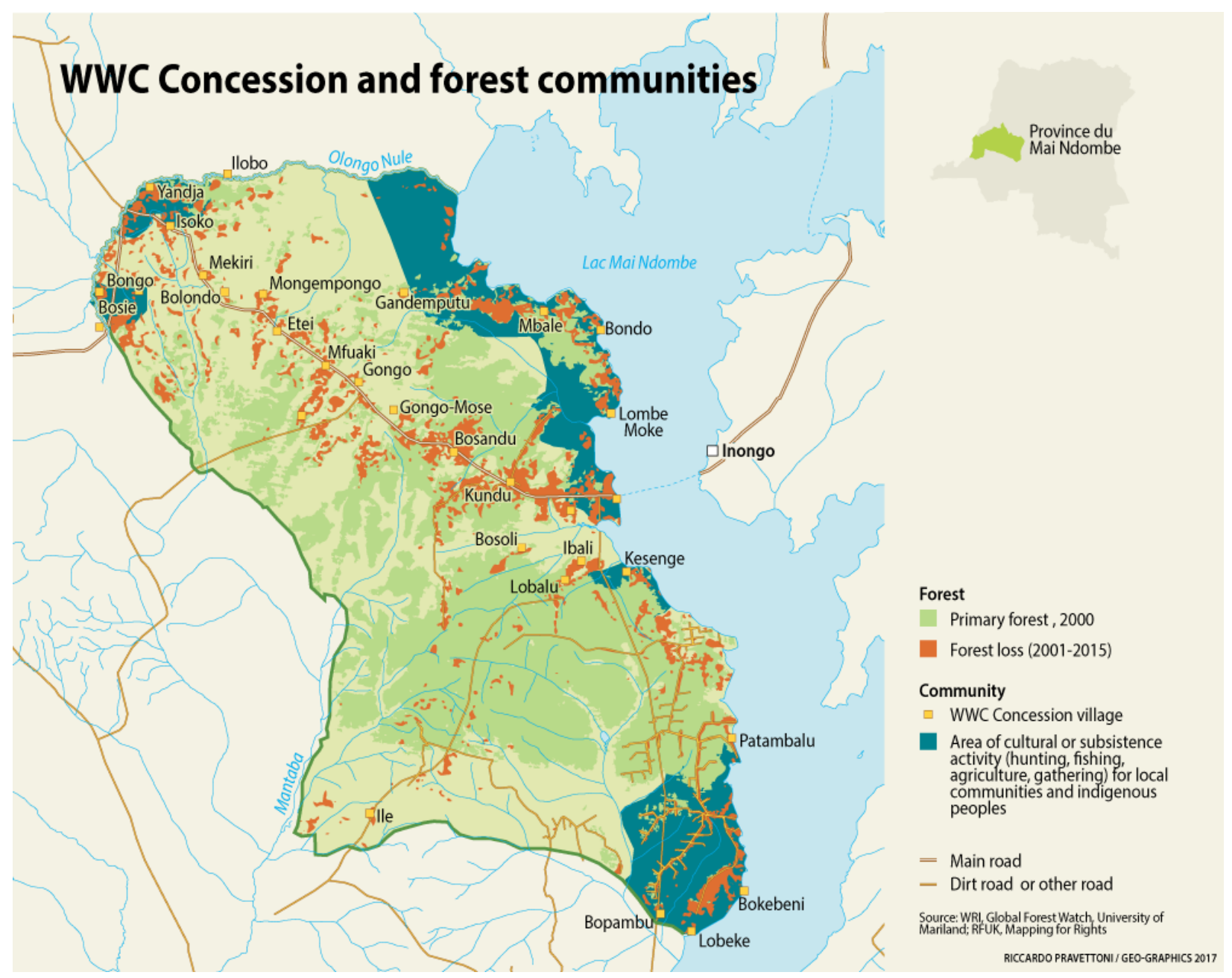

Weak recognition of conflicts in REDD+ initiative planning harms their ability to produce results

The land issue and the impact of land conflicts on REDD+ outcomes are largely absent from all national level programs and discussions. Land reform seems to be an autonomous element, without its leaders being included in ongoing consultations on REDD+ governance. However, conflicts have so far been identified as the main reason for the restrictions of forest reforms in the Democratic Republic of the Congo. ${ }^{103}$ Given the historical and current context of political instability and conflict in this fragile state, these issues should be addressed more broadly in REDD+ implementation projects. Since conflicts directly threaten land use planning, on what basis can a planning process be carried out without any knowledge and clarification of the existing land rights in that same territory? How can this planning process be made participatory if not all the area's actors can be represented and claim their rights to the land? What legitimacy do assignment decisions have when taken in a conflict context? On the other hand, land conflicts involve a risk of displacement of deforestation. In cases of conflicts between communities and concessionaires, communities deprived of their land 
but not benefiting greatly from REDD+ are pushed to continue or even increase forest degradation activities to obtain new arable land, causing the deforestation itself to be displacemed, Yet the Cancun safeguards recommend that REDD+ activities include measures to reduce the movement of emissions. ${ }^{104}$ In this context, an effective land conflict management system is an indispensable preventive measure.

\subsection{REDD+ activities' structure: lack of environmental and community anchoring}

\section{The initial design of REDD+ in Mai-Ndombe is not realistic}

Both PIREDD and the ERP are planning activities across the province to cover the drivers of direct (through so-called sectoral activities) and indirect (enabling activity) drivers of deforestation in the area. ${ }^{105}$ These projects are therefore superimposed in terms of activities, but should not be implemented at the same time, as ERP funding will take over from those considered as "prerequisites"106 of the PIREDDs. Yet when the ERP was designed, CAFI did not yet exist and no prefunding was planned. The revision of the project sequence and the addition of programs called "prerequisites" a posteriori thus attest to erroneous and unrealistic initial planning in the ERP IN, despite it being validated in 2014. The NSK project, which was meant to test REDD+ in the field, was ultimately not certified, as the cost of certification was too high and not planned for in initial budgeting. Other projects, not designed with a REDD+ orientation (SOCALCO's supply of wood for matches), are now registered in the ERP project and would like to eventually join the REDD+ projects. This scenario suggests a patchwork initiative, made of multiple unrelated initiatives designed in different times, seeking a posteriori to create a link to and capture REDD+ benefits.

The various initiatives do not benefit from a consultation framework despite their multiple overlays.

The concentration of REDD+ activities in the area involves multiple overlaps of beneficiaries, of geographical areas involved and themes addressed, and of targeted drivers of deforestation. Despite these overlaps, there is no consultative framework connecting the various initiatives. This coordination should be provided for in the CAFI-funded "governance" program implemented by the World Bank, through the establishment of discussion forums among the three main donors--CAFI, FIP and FCPF--but not with all actors related to REDD+. Ad hoc meetings are also organized on specific topics, but not all actors participate systematically. For example, UN-Habitat, which ensures the implementation of land reform, did not participate in ad hoc consultations on profit sharing. An inclusive and permanent consultation is all the more crucial as each driver of deforestation is approached in parallel by different initiatives. For example, land use planning, a key pillar of REDD, is tackled by eight different initiatives. Some address it at the national level (land use planning reform, whose implementation in Mai-Ndombe is entrusted to PIREDD), others at the provincial level (ERP), the district level (PIREDD), in the context of localized projects (Novacel - South Kwamouth) or at other levels (in the "landscapes" as defined by CARPE ${ }^{107}$ ), without these initiatives working together. For example, the ERP responds to the challenges of land use planning and land insecurity by creating "sustainable development plans" by the FTA at the local level, just like the PIREDDs. CARPE 
does not mention these PDDs despite their being implemented in the same area, and is already working on management plans or simple management plans through micro-zoning activities. ${ }^{108}$

\section{Local development committees, pivotal community structures in the majority of projects, operate opaquely and are not representative}

Officially composed of community representatives, the CLDs are structured for information, consultation, and decision making at the local level, as defined in PIREDD. The latter plans to create 150 CLDs in the Plateau District and 600 in the Mai-Ndombe District. As part of the land-use planning reform, land reform, and ERP reform, they will be responsible for the development and validation of local land use plans through participatory mapping, and will sign a contract that engages the community. ${ }^{109}$ Despite their importance, little information is available on their constitution, their mode of operation and therefore their legitimacy. Their relationship with the decentralized territorial entities is not defined, although they are both identified as potentially responsible for managing natural resources arbitrations. ${ }^{110}$ Despite requests, no CLD meetings reports were shared by the PIREDD Plateau FTA, WWF. Criticisms were raised, by REPALEF in particular, about their representativeness, as only 10 percent of the representatives are indigenous and benefit only from a limited effective speaking right. ${ }^{111}$ The CFLEDD noted, during its mission in the Kiri territory, that only land chiefs sit on the CLDs. ${ }^{112}$ The WWF and CFLEDD "local community outreach" program could address this through women's outreach activities, although this project has only been carried out in a few communities. The history of the CLDs also raises doubts about their effectiveness: created in the Mai-Ndombe by the WWF to negotiate the terms of reference with SODEFOR, they had been the origin of many conflicts, as communities denounced arbitrary selection of their representatives within the CLDs and the monopolization by these individuals of profits, as well as the signing of non-legitimate agreements. ${ }^{113}$ Today, local organizations request that the structuring of communities in the context of negotiations be delegated to the local level, allowing communities to decide how to best structure themselves rather than have the structure imposed by consultants from Kinshasa.

\section{Drivers of deforestation are little known locally}

When studying the drivers of deforestation, ${ }^{114}$ it is commonly accepted among project proponents that "in general, the causes of [the] reduction in forest cover in Mai-Ndombe are identical to those identified at the national level."115 This study has been the subject of much criticism from civil society, particularly on the issue of shifting slash-and-burn agriculture ${ }^{116}$ and industrial logging, both ignored despite being consistently pointed to by communities as sources of deforestation. The ERP estimates that shifting slash-and-burn agriculture is the leading cause of deforestation and forest degradation, followed by energy wood production (charring) and smallscale or artisanal logging. It also points to poverty; lack of economic and technical alternatives; mismanagement of

Despite these lines of thought, no study has so far been carried out regarding the drivers of deforestation at the provincial level. Many analysts agree on the need for a deeper analysis of the drivers of deforestation from the local level and into the territories as part of the development plans that will be implemented. natural resources, unregulated land tenure; population growth; and increased demand for 
agricultural products, charcoal, and land. The 2016 study by FPP on the drivers of deforestation considers that if the pressure to supply the capital with agricultural goods and charcoal is very strong in the Batéké plateaux, south of the province of Mai-Ndombe, there is insufficient evidence to say that agriculture contributes significantly to deforestation outside peri-urban areas and this Kinshasa watershed. ${ }^{117}$ Despite these lines of thought, no study has so far been carried out regarding the drivers of deforestation at the provincial level. Many analysts agree on the need for a deeper analysis of the drivers of deforestation from the local level ${ }^{118}$ and into the territories as part of the development plans that will be implemented. While CAFI's civil society support program does provide for a provincial study of the drivers of deforestation, indicating its participation in these new studies in 2017 and 2018, ${ }^{119}$ such studies are not mentioned in any other program document. The PIREDD Mai-Ndombe, which is also funded by CAFI, expresses the opposite by stating that the section proposed in the ERP D as well as its provincial overview annex are sufficient to define the provincial drivers of deforestation.

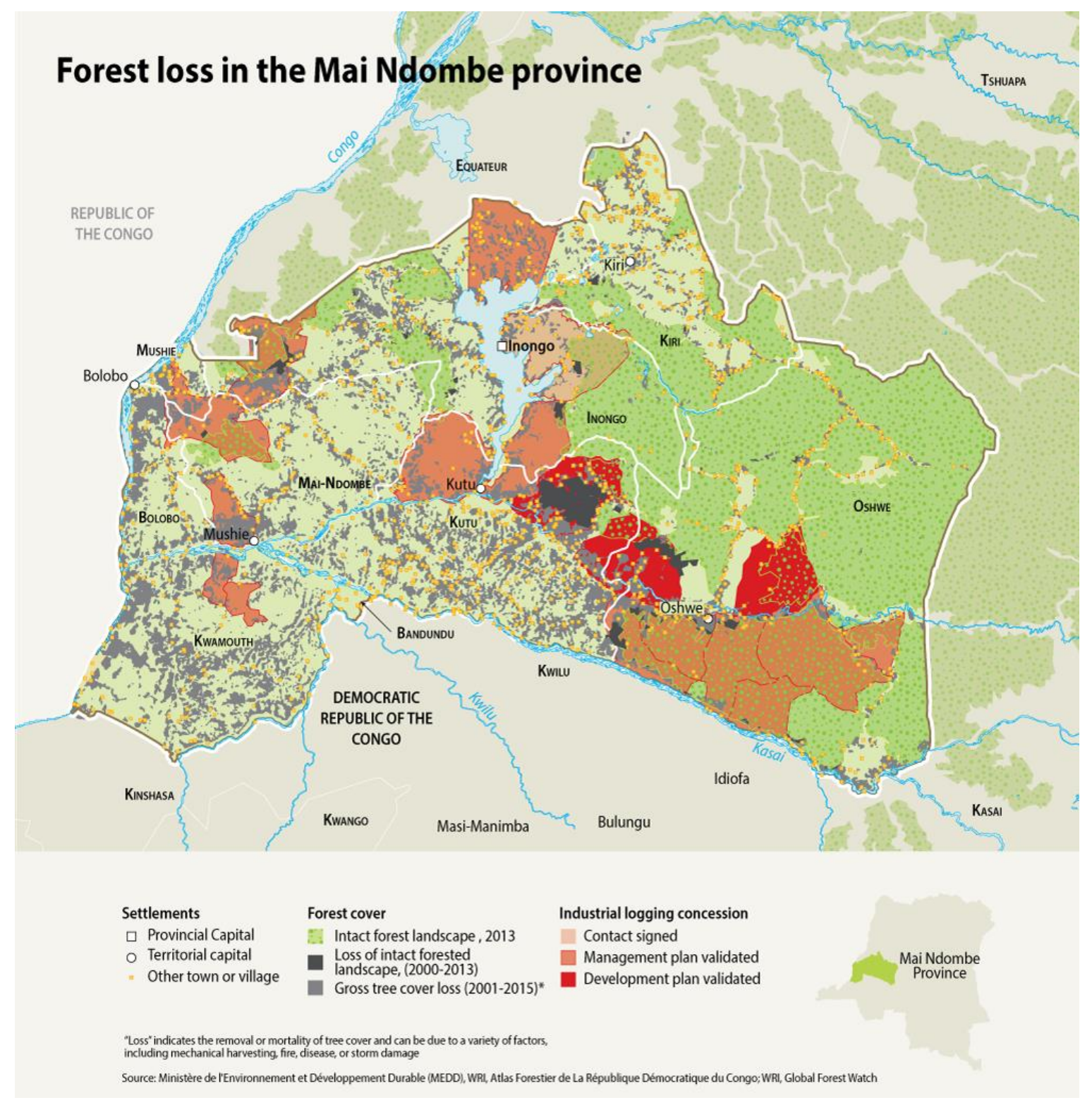


The 20 programs and initiatives identified by this study in Mai-Ndombe do not address all of the current and future drivers of deforestation within the province.

The planned activities are not fully consistent with the list of identified drivers, which means they will not address the structural characteristics responsible for deforestation. Although the enabling pillars of land, governance, and land use planning are well taken into account, few activities deal with local communities' land insecurity, which has been singled out as the main driver of deforestation. In addition, the current list ignores the present but still untapped resources in the province (oil slick under the territories of Oshwe, Inongo, Kutu and Kiri; coltan in Bolobo; and diamonds in Yumbi). These are not yet drivers of deforestation due to a lack of extraction infrastructure and resources available at an attractive cost for investors. However, this could change, as infrastructure improvement is being targeted by PIREDD. Therefore, the potential impact of these activities should be considered in a long-term forecast of REDD. Ignorance of the migratory phenomenon suggests that processes of land-use change, such as non-permanence of forestry or agricultural activities, likelihood of "leakage," or displacement of emission sites, are not sufficiently taken into account, both over the long term and provincially. In this context, REDD+ projects could act like "virtual emission reduction machines" designed to inflate the production of carbon credits without acting structurally on the economic characteristics ${ }^{120}$ or on key infrastructure such as the electrification of towns and villages. 
Table 2. Drivers of deforestation targeted by REDD+ initiatives in Mai-Ndombe

\begin{tabular}{|c|c|c|c|c|c|c|c|c|c|c|c|c|c|}
\hline \multirow{2}{*}{$\begin{array}{l}\text { Initiatives linked } \\
\text { to REDD+ } \\
\text { Mai-Ndombe } \\
\text { Emmissions } \\
\text { reduction program } \\
\text { (FCPF) }\end{array}$} & \multicolumn{7}{|c|}{ Direct drivers } & \multicolumn{6}{|c|}{ Indirect drivers } \\
\hline & $\begin{array}{l}\text { Shifting } \\
\text { slash-and- } \\
\text { burn } \\
\text { agriculture }\end{array}$ & $\begin{array}{l}\text { Carboniza } \\
\text { tion - } \\
\text { energy } \\
\text { wood }\end{array}$ & $\begin{array}{l}\text { Industrial } \\
\text { logging }\end{array}$ & $\begin{array}{l}\text { Artisanal } \\
\text { logging }\end{array}$ & Bushfire & $\begin{array}{l}\text { Agricultural } \\
\text { enterprise }\end{array}$ & $\begin{array}{l}\text { Mining } \\
\text { enterprise }\end{array}$ & $\begin{array}{l}\text { Lack of land } \\
\text { use } \\
\text { planning }\end{array}$ & $\begin{array}{l}\text { Land } \\
\text { insecurity }\end{array}$ & $\begin{array}{l}\text { Demograp } \\
\text { hic growth }\end{array}$ & $\begin{array}{l}\text { Infrastruct } \\
\text { ure and } \\
\text { urbanizati } \\
\text { on }\end{array}$ & $\begin{array}{l}\text { Governa } \\
\text { nce }\end{array}$ & Poverty \\
\hline $\begin{array}{l}\text { Plateau REDD+ } \\
\text { Integrated Program } \\
\text { PIF }\end{array}$ & $x$ & $x$ & $x$ & $x$ & & $x$ & & $x$ & & $x$ & $x$ & $x$ & \\
\hline $\begin{array}{l}\text { Mai Ndombe } \\
\text { REDD+ Integrated } \\
\text { Program CAFI PIF }\end{array}$ & $x$ & & & & & $x$ & & $x$ & & & $x$ & $x$ & $x$ \\
\hline $\begin{array}{l}\text { Indigenous Peoples } \\
\text { Development Plan }\end{array}$ & & & & & & & & & & & & & $x$ \\
\hline $\begin{array}{l}\text { Support project for } \\
\text { forest-dependant } \\
\text { communities }\end{array}$ & & & & & & & & & & & & & $x$ \\
\hline $\begin{array}{l}\text { CAFI land use } \\
\text { planning reform }\end{array}$ & & & & & & & & $x$ & & & & $x$ & \\
\hline $\begin{array}{l}\text { Support to CAFI's } \\
\text { land reform }\end{array}$ & & & & & & & & & $x$ & & & $x$ & \\
\hline $\begin{array}{l}\text { CAFI Sustainable } \\
\text { forest management } \\
\text { project }\end{array}$ & & & $x$ & & & & & & & & & & \\
\hline $\begin{array}{l}\text { CAFI Civil society } \\
\text { support program }\end{array}$ & & & & & & & & & & & & $x$ & \\
\hline $\begin{array}{l}\text { WWC Conservation } \\
\text { concession }\end{array}$ & $x$ & $x$ & & & & & & & & & & & \\
\hline
\end{tabular}




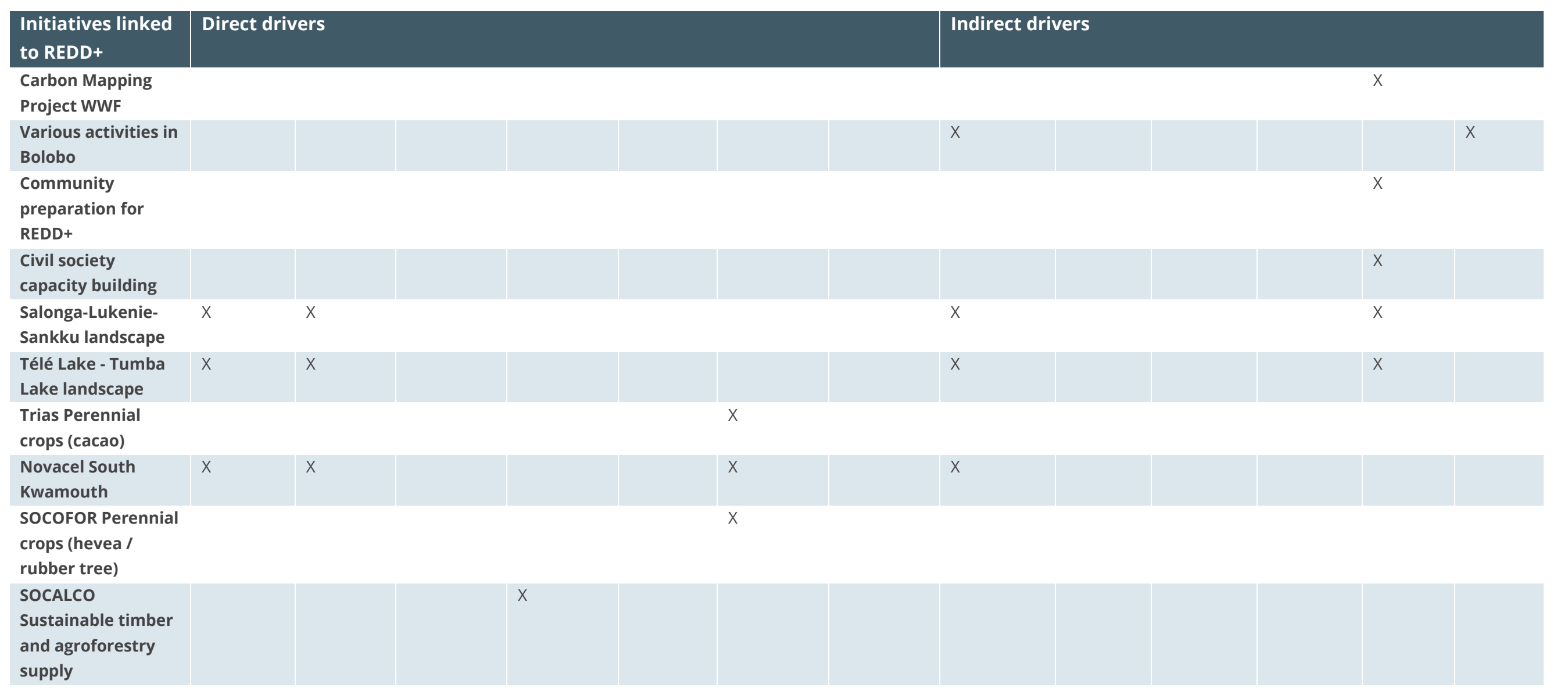


REDD+ funding support to industrial logging does not account for the drivers of deforestation as targeted by current projects, nor for the industry's destructive reality in the field

Although industrial logging is not mentioned as a major driver of deforestation, the CAFI program is open to financing a sustainable forest management program of AFD, one of the objectives of which is support to the industrial logging sector. In addition to the controversy surrounding the use of development aid funds to subsidize the private sector, one must also question coherence when faced with the channeling of REDD+ funds towards this sector, deemed non-priority for the reduction of emissions. It is also worrying that this program was designed in a framework that underestimated this sector's impact on the forest, given that the study conducted by FPP highlights the role of industrial logging, both legal and illegal, as a driver of deforestation. ${ }^{121}$ The map providing comparisons between net forest loss and industrial logging concessions shows the largest net losses in forests in SODEFOR concessions. The DRC's independent observer for forest governance has identified numerous business offenses, exceeding the authorized volume or lack of permits. ${ }^{122}$ Beyond the unknown cutting figures of semi-industrial companies, industrial farmers could actually export volumes of timber up to seven times higher than official figures indicate. ${ }^{123}$ In addition, industrial exploitation leads to an often irreversible process of deforestation. Natural regeneration is prevented by the agricultural fields which settle, with the opening of the canopy, on the open skid trails. Rainforest Foundation UK has also identified more than ten potential new concessions which, if the moratorium is lifted, would be directly superimposed on high-carbon peat swamp forests and threaten to release up to 30 tons of $\mathrm{CO} 2$ per hectare. ${ }^{124}$ In line with the Fifth Cancun Safeguard, studies still need to be done to assess the real impact of deforestation caused by this activity and to ensure that support for industrial logging is not synonymous with conversion of natural forests. The Fifth Safeguard stipulates that the measures must be compatible with the conservation of natural forests and biological diversity, ensuring that activities do not lend themselves to conversion of natural forests but rather encourage the protection and conservation of these forests and the services rendered in their ecosystems, as well as to enhance other social and environmental benefits. ${ }^{125}$ In this context, AFD's program has been the subject of strong criticism from civil society, which blocked its approval temporarily. An update of this program should be submitted to CAFI.

\subsection{Right to land: isolation of the problem and not taking into account land dynamics}

\section{A lack of knowledge and understanding of land dynamics}

The very nature of REDD+ projects, particularly those that are intended to generate carbon credits, raises the issue of carbon rights. The carbon that REDD+ is concerned with is related to the forest, better yet to the tree, which links the right to carbon to the tree or forest regime. The World Bank's Carbon Fund Methodological Framework provides, in criterion 28, that "the emission reduction program reviews the assessment of land tenure and resource rights undertaken the national level during the preparation phase (i.e. SESA) and, if necessary, complete this work through an assessment of any land and resource ownership issues in the area of accounting that may be critical to the successful implementation of the program." If the revision was indeed carried out and gave rise to the series of measures developed in the safeguards, no substantive evaluation of the project area was carried out. Yet, in light of the major land issues and the complexity of overlapping customary and state systems, such an evaluation is crucial to the successful implementation of the program. The safeguarding measures developed are not sufficient and major gray areas remain in 
the operationalization of these measures. In particular, they ignore the impact of customary law on land and the lack of ownership of state-sanctioned land titles by most communities. They also do not provide guidance on how to address the risks of carbon rights ambiguity when they overlap with customary or non government-sanctioned rights. These problems could be clarified by additional studies to be carried out in each accounting area, but this has not been done to date. The BioCFplus study, which is the main reference for ERP and Mai-Ndombe PIREDD alike, offer a global description of tenure without detailing the dynamics and issues at the local level, and without clarifying the links between land rights and carbon rights.

\section{A lack of communication between the land reform program and other REDD+ projects, which could prevent the proper implementation of the reform}

Paradoxically, while many projects incorporate a land

use planning component, few address the land issue in a comprehensive way. Only the land reform support program, supported by CAFI and led by UN-Habitat, addresses the question of securing land tenure for communities directly, without however mentioning the migratory issue. It provides for a land security pilot project in the province of Mai-Ndombe that will anticipate national reform and include support for communities as a strategic intervention axis. However, no details are given on this pilot and only activities like "basic study" and "establishment of a land information system" are detailed in the schedule of planned activities. Currently, this program seems to be disconnected from the other REDD+ projects, even though it provides for unspecified coordination. For example, project managers are neither informed nor consulted on key issues, such as the benefit sharing plan. The plan is nevertheless extremely closely linked to land tenure issues, since the sharing of benefits is based on the identification of rightsholders and thus on the clarification of land tenure. The arrival of REDD+ benefits in Mai-Ndombe, in a situation with existing pressure on land, can only exacterbate existing pressure on land and its appropriation. The links between benefit sharing and land reform are therefore crucial. Ongoing activities in the area are also likely to limit the results of land reform if they occur before harmonization between customary and state land tenure.

\section{Failure to take the issues of migration and sharecropping into account challenges the effectiveness of projects, while the accumulation of projects may amplify these issues}

The migration phenomenon is not taken into account in any of the project planning. Yet it impacts them greatly. On the one hand, the accumulation of agricultural and agroforestry projects is likely to intensify this phenomenon, bringing more migrants to the project areas and causing an increase in the number of "landless peasants" whose role in REDD+ and whose share of benefits will need to be 
clarified in view of their lack of land rights. On the other hand, their presence leads to additional (but currently unquantified) demographic pressure on forests and on the price of land, amplifying inflation. This is already the case on the Batéké plateaux, where industrial plantations have attracted low-cost, seasonal, and precarious labor. This non-consideration also calls into question the effectiveness of projects: if landowners are the projects' beneficiaries, as they now rent their fields, they are not actually the main actors of deforestation at the local level. This suggests that the results in terms of reducing deforestation would be minimal. In contrast, the success of plantations in the village of Botulu seems to be attributable to the area's homogeneity. The rightsholders all belong to the same community and enjoy equal and secure access to land, which results in a good, nonconfrontational dynamic, and thus the village's strong willingness to participate actively in the project on their land, without the risk of having plantations or income confiscated from them. This example illustrates the importance of land clarification and the threat posed by land insecurity to the capacity of the most vulnerable actors to take ownership of REDD+.

\section{Community forestry, an underutilized approach to REDD+ in Mai-Ndombe, is discussed in the margins and not considered as a tool for community ownership of REDD+}

Community forestry, a tool for securing communities' land tenure and thus reducing deforestation, does not appear as a priority within REDD+ initiatives, despite being classified as an enabling pillar of REDD+. No community tenure clarification tool, such as local communities' forest concessions, is planned at the provincial level in the Mai-Ndombe initiatives. This makes the REDD+ process and its benefits inaccessible to communities, and offers a significant advantage to private sector industrial project owners who are able to obtain land and benefit from carbon rights. In addition, the community forestry approach currently proposed in Mai-Ndombe through AFD's sustainable forest management initiative does not support securing customary tenure, but rather aims at reinforcing territorial administration. In this scenario, the CFCL would be equivalent to the decentralized territorial entities, that is to say to administrative limits which do not correspond to customary tenure. This would create CFCL limits contradicting the customary limits, making them vulnerable to appropriation by the territorial administration in charge of this space. Support to CFCLs should therefore be reviewed and will have to be accompanied by increased support to CLDs-or any community management structure-to avoid capture of benefits by the local elite. This support for communities' land tenure security is crucial: clarity on tenure rights would indeed determine the level of community participation (of both men and women) in decision-making processes related to the rights and responsibilities associated with REDD+ activities.

\subsection{Rights of Indigenous Peoples: A compensation strategy without secure rights}

\section{The strategy of "compensating" Indigenous Peoples does not lead to securing their rights}

PAs are directly targeted by World Bank Operational Policy 4.10, the Third Cancun Safeguard and the DRC Indigenous Peoples Plan, which is an integral part of the safeguarding tools for REDD+ initiatives in Mai-Ndombe. The IDA project supports the creation of development plans for 
Indigenous Peoples, while micro-projects of the support project for forest-dependent communities are implemented by REPALEF. These projects, located in villages or specific chiefdoms, are intended to be taken on in the context of future development plans and land use planning plans carried out on a larger scale, but the modalities of this consideration cannot be described in detail. Developed as special support funds, microprojects are a compensation strategy aimed at vulnerable populations. However, they do not integrate the rights of Indigenous Peoples and the improvement of their living conditions into the enabling pillars of REDD+. Above all, in the absence of recognized land rights for Indigenous Peoples, no development plan or microproject developed has any legal basis in tenure, and therefore support or mitigate the risks of increased precarity of vulnerable populations in a sustainable manner, a precarity that lies in the balance of the accumulation of REDD+ initiatives in the Mai-Ndombe.

\section{Indigenous Peoples are not considered in the enabling pillars}

In the absence of an equitable, implemented benefit-sharing system, REDD+ initiatives implemented to date are likely to benefit landlords and industrialists more than marginalized groups, and to make the latter more precarious. Larger REDD+ programs, such as land use reform or the Mai-Ndombe PIREDD, do not include any specific consideration of Indigenous Peoples. Without any work to identify the different groups and indigenous camps throughout the province, this consideration is currently impossible. However, the work of Indigenous Peoples groups and REPALEF is moving in this direction and should be used as part of the land reform process. The latter, as part of its pilot project, should also not underestimate the indigenous problem and choose an implementation area where Bantu and Pygmy populations live side by side, in order to integrate PAs into the land securization to be undertaken. The failure to include Indigenous Peoples in the enabling pillars of REDD+ is not in line with the above-mentioned norms, which specify that activities must "promote respect for the knowledge and rights of Indigenous Peoples and members of local communities, taking into account, in particular, international [...] obligations such as the United Nations Declaration on the Rights of Indigenous Peoples,"126 and thus guaranteeing Indigenous Peoples the possession, use, development and control of their territories. ${ }^{127}$

\subsection{Gender: Women are still at the margins of REDD+ projects}

\section{The gender approach is limited to family planning}

Gender is mainstreamed as one of the components to be considered in all programs, with a focus on advocacy and consideration of the interests of "women, youth, Indigenous Peoples, and vulnerable groups." 128 However, the modalities of this consideration and the activities enabling it are not detailed. In fact, in both the ERP and Mai-Ndombe PIREDD, the issue of demographics, addressed through family planning activities, is the only pillar of REDD+ to target women directly. These programs offer a series of activities aimed at regulating population pressure in the area (through the encouragement of "birth spacing") and recognize their "central responsibility for family reproduction." This does not acknowledge the role of women in traditional forest management and practices. In addition, the CFLEDD notes that this is a necessary but delicate activity, and recalls the importance of not rushing things: if living conditions do not evolve, changes in mentality will also be difficult. The planned activities provide easier access to contraceptives, education, and information 
programs with the support of opinion leaders, but do not take into account the diverse categories of women (rural women, indigenous women, urban women, girls, married women, divorced women, widows, etc.) and the different challenges they face. Only girls and their living conditions are specifically targeted through the promotion of their access to employment, making it possible to delay the age at which they bear their first child. All of the different challenges for women should be defined and targeted in this way, allowing this program to be refined.

\section{Support for women's participation in CLDs needs to be encouraged}

CERN and CFLEDD admit that the goal of 30 percent of women in CLDs is rarely achieved, and especially that women's expression is nonexistent. ${ }^{129}$ Without specific, systematic and independent support for women's leadership, women's participation in decision-making bodies, and thus their ability to influence decision-making processes so that their rights are recognized, may be compromised. This situation is in direct contradiction with the directives of the Ministry of the Environment, which demands respect for gender in the establishment of local communities' forest concessions' management bodies. ${ }^{130}$ Regarding rural women, the PIREDD Mai-Ndombe provides, in parallel with each CLD, the creation of women's associations whose president will sit on the CLD. In this context, the representatives should be able to defend the interests of women in the negotiations of simple management plans affecting their living spaces. This approach is still limited to one project and the 600 CLDs concerned. As part of its community outreach program, WWF has developed a project to support CLDs in Kutu, Inongo, and Kiri provinces on gender issues in collaboration with CFLEDD. This work is a path to emancipation. Such a project does not yet target indigenous women.

\section{Women are still at the margins of REDD+ projects, which does not allow for their emancipation}

The national REDD+ legal framework will need to clarify the ability of holders and non-holders of tenure rights to access REDD+ revenues, as women are almost systematically non-bearers. To date, PIREDD Mai-Ndombe anticipates that payments for environmental services, at a minimum rate of 10 percent, go to women. This new "compensation" strategy dodges the issue of securing women's land tenure and threatens their equitable access to payments for environmental services beyond the 10 percent target. Excluding women from land management threatens their contribution to the implementation of the national REDD+ framework strategy and their potential to benefit from it. In the context of land reform, the question of securing women's land tenure is all the more important since women are sometimes excluded due to the discriminatory interpretation of customary law, but this issue is not addressed. Given the gap between women's rights as defined by international law and those implemented by the government, land reform and community forestry should instead support the recognition of women's customary rights and not choose between recognizing women's rights and recognizing community rights. A previous Rights and Resources Initiative study on women's rights to land in more than 30 low- and middle-income countries shows that legal advancement of women's rights usually goes hand-in-hand with those of their communities. ${ }^{131}$ Women's lack of access to REDD+ benefits contravenes the international human rights framework and the conventions and standards ratified by the DRC, and would threaten the sustainability of the proposed measures, as well as half of the population's adherence to the latter. On the contrary, it is essential that the REDD+ process recognize women's land tenure in their strategies and projects on the ground, ensure equitable access to resources, knowledge and decision-making processes, as 
well as funding and support for access to REDD+ benefits, and encourage women's entrepreneurship. Securing women's land rights would in fact enable their financial empowerment and thus their ability to save for the needs of the family, thereby promoting better access to education and breaking the cycle of poverty.

\subsection{REDD+ benefit sharing: risks compromising REDD+ objectives}

\section{The benefit-sharing plan fails to ensure that REDD+ benefits local communities and Indigenous Peoples}

The ERP benefit sharing plan is not yet finalized. The analysis proposed here is therefore based on its March 2017 version as well as the exchanges held with the FCPF and the World Bank in July 2017. However, the FCPF Methodological Framework needs to be made public "at least in the form of a draft, in a language that allows stakeholders to read it, before an Emission Reduction Agreement (ERP-A) is signed."132 To date, the draft proposal proposes that the following costs be shared:

- a fixed amount for a program management unit, which will be responsible for ensuring that safeguards are respected and the sale of surplus carbon credits are not sold to the FCPF;

- a fixed sum for the national and provincial government;

- 2 percent of all money received for local communities and Indigenous Peoples, donated to FONAREDD and reinvested in local community projects;

- the rest will consist of performance-based payments to approved project holders.

According to this sharing, communities living in project areas will directly depend on REDD+ project holders to benefit from REDD+ revenues. However, historically, whether in mining, forestry, or conservation concessions (WWC), the terms of reference are either not realized or not respected by operators, and profits are very rarely redistributed to communities. ${ }^{133}$ CN-REDD itself noted in 2012 that poorly-defined revenue sharing was one of the main risks for corruption, which could lead to misappropriation of funds. ${ }^{134}$ Civil society organizations have requested that it be reviewed, finalized, and endorsed by all stakeholders before any signing.

\section{A benefit-sharing plan could undermine land reform efforts and undermine the security of local communities' rights}

REDD+'s neo-liberal approach, which does not include securing communities' land rights, can favor the emergence of private actors and diminish the State's responsibility for the preservation of its forests and its support to communities. This trend modifies the conditions of access to the land and contributes to the dispossession of lands, creating a "green-grabbing" phenomenon. ${ }^{135}$ This privatization of REDD+ is already under way in the context of the WWC conservation concession, which is currently the only Congolese REDD+ project authorized to sell carbon credits. The new Homologation Regulation, intended to replace the current text, ${ }^{136}$ should allow any legal entity, including the comités locaux de développement (Local Development Committee, or CLD), which justifies land rights in the area, to become a project leader. However, the CLDs, beyond their structural problems mentioned above, are not entities with land rights, and the projects propose few ways to allow this land to be secured. Absent a plan to facilitate and accelerate the recognition of local communities' land rights, notably through support for community forestry, this decree does not allow communities to become project leaders. In this context, communities could only benefit 
from the small share that is offered to them (2 percent), without REDD+ recognizing their direct contribution to national efforts to reduce deforestation. This 2 percent strategy thus constitutes a dangerous way of avoiding the issue of land security. The benefit-sharing plan is therefore likely to undermine the efforts of land reform, which must clarify the duality between legal and customary rights, preventing it from offering communities any prospects of tenure security.

\section{A benefit-sharing plan that fails to achieve the goals of REDD+}

REDD+'s effectiveness is undermined due to a failure to take into account the most vulnerable actors and ignoring the issue of non-rights holders such as women, migrants, or young people in benefit sharing. If the PPB were to remain what it is today, there is a risk that REDD+ activities will not benefit the vast majority of stakeholders and therefore not have the expected impact in terms of programmatic and development co-benefits. However, the CAFI programs, which are independent of the carbon market, meet this objective, making it possible to release funds according to a classic model of development aid, i.e. public expenditure in the form of donations, packaged not with an eye to carbon performance but to national development results. Conversely, in the REDD+ scheme, private sector or WWF-managed initiatives are those in the DRC currently best positioned to be remunerated directly by REDD+ without depending on national results. Yet none of these projects can, to date, demonstrate their impact on deforestation reduction at the local level, or guarantee that communities will be the primary beneficiaries.

\subsection{Improvement of living conditions: poorly-targeted beneficiaries and poorly-controlled impacts}

\section{Recipients are poorly identified and unknown}

In the absence of a national census, the figures assessing the population of Mai-Ndombe are only estimates, at 1.5 million inhabitants. Large programs such as PIREDD and ERP therefore announce targeting this entire population, though the population remains poorly defined. With regard to the district of Mai-Ndombe, which has about 1.1 million inhabitants, the BioCFplus study announces a total of 1,371 villages listed and geo-referenced, representing 1,100 terroirs ${ }^{137}$. The PIREDD program document announces 1,300 terroirs in the same district. ${ }^{138}$ These inconsistencies attest to a lack of knowledge of the area and the beneficiaries themselves. On the other hand, if the entire population are beneficiaries, PIREDD somehow only plans for the creation of 600 CLD in 600 terroirs along roads and rivers. As PIREDD is responsible for leading the land use planning reform at the provincial level with the support of the CLDs, community involvement and work planned in the non-targeted terroirs are lacking.

\section{No project can yet prove its positive impact on the living conditions of local communities}

Poverty reduction and improvement of livelihoods in communities are objectives for all projects, as evidenced by the $\mathrm{CAFI}^{139}$ letter of intent and the ERP program document. ${ }^{140}$ Community-based agroforestry activities have an important community component, contribute to food security and, more generally, increase the incomes of rural households. However, unregulated land tenure and the neglect of migration and population movements raise doubts about REDD+ initiatives' ability to 
benefit the poorest actors and to improve living conditions in the province. The income survey undertaken through the Novacel project did not identify an increase in income for farmers. However, it seems that the quality of life has increased, with money now remaining in the village rather than being spent on the way by men who travelled the road to Kinshasa to sell their charcoal production. Road rehabilitation and the increase in production, which justify the arrival of a truck during the two cassava-harvesting periods, spare producers from travelling and allow for the money to be managed by the women. ${ }^{141}$

\section{Support initiatives to improve living conditions remain localized and lead to a risk of population displacement and deforestation}

As the NSK project in Ibi village shows, agro-forestry projects based on participatory approaches and community empowerment in a land security context have great potential to improve the living conditions of communities. Adequate agricultural planning can also reduce the risks of food insecurity, with some of the production remaining in the village as encouraged by the NGO Trias. But these initiatives are still too sparse. Outside the limited areas of micro-project implementation, initiatives do not present a coordinated approach that can reverse the provincial trend. The buildup of initiatives to improve populations' living conditions in specific places also risks creating displacement phenomena in both deforestation and people, without these phenomena so far being taken into account in risk management.

\subsection{Stakeholder participation and accountability: low community ownership}

\section{Communities are uninformed about REDD+, compromising popular support}

The UNDP mission conducted in May 2014 as part of the Tier2 REDD+ readiness project found local community representatives and Indigenous Peoples had very limited knowledge of REDD+, even in Inongo. Many participants were not aware of the current process, or its implications and consequences for their land. This lack of information can lead to frustration and conflict, but also and above all to a lack of involvement of the most distant territories, which are sometimes the ones most directly affected by REDD+ issues. Within the province, information has, for the moment, been mainly the responsibility of project leaders. Much confusion emerged from botched awareness campaigns during the WWC concession. Confusion around the creation of an "air market" and "air sequestration" has made communities believe that they would be deprived of the air they breathe. The lack of information available in a community-friendly format is a major obstacle to the free and prior informed participation of communities in a process directly impacting their lands and livelihoods, while compromising popular support for REDD+, even in cities. Bato ya REDD (REDD people) are often not welcome: in Basengele, the NRN / RFUK teams were chased away by the communities because they were mistaken for bato ya REDD, or members of ERA. Many are reluctant to pronounce the name of ERA aloud in Inongo, for fear of attracting suspicions. Local civil society organizations, members of the GTCR-R, have started to develop awareness tools adapted to the local context. Better mobilization of these tools and the many skills available in the provinces would help to address this issue. 


\section{Uneven and partial application of FPIC}

The national REDD+ body's FPIC guide is a key tool to enable the participation of local communities and Indigenous Peoples to REDD+ projects. It was developed in December 2015 by the CN-REDD on the basis of contributions from WWF, FPP, and the GTCR-R, and international standards in this area. It includes milestones, criteria, and indicators denoting audit points. Both ERP and PIREDD refer to it, as do safeguard documents. It was to be reviewed after field trials but, faced with the cessation of funding from CN-REDD, this project remains on hold. Moreover, the fact that is was conceived after the REDD+ projects challenges its applicability, since the REDD+ projects could not have followed its guidelines during their design and implementation. Most of the communities which the OGF's and Moabi independent observation missions met in Mai-Ndombe did not participate in defining the activities carried out by the projects. Their rights of use were not mapped prior to drafting, and they did not have direct access to information. Given these weaknesses, projects cannot yet claim to be systematically conducted in the spirit of FPIC, even though FPIC is promoted by all programs as a foundation of their actions. ${ }^{142}$ The application of FPIC would, however, ensure REDD+ initiatives in Mai-Ndombe comply with the Fourth Cancun Safeguard by promoting full and effective participation of relevant stakeholders in activities, particularly with regard to Indigenous Peoples and local communities; ${ }^{143}$ this compliance is currently absent.

\section{The potential of participatory approaches is under-used}

Participatory approaches, such as participatory mapping, have been promoted by civil society as a tool for community involvement. This tool is planned for in the ERP, the two PIREDD projects, land use reform, the two CARPE landscapes, the support program for civil society, and proposed as a mitigation measure in the safeguarding documents. However, one must question the methodology used and its results. WWF, whose methodology is used for CARPE programs in Bolobo and for the PIREDD Plateau, relies in particular on CLDs to represent communities in the participatory mapping process. CLD's weakness and their lack of representation are, however, major obstacles to local communities' full and effective participation, particularly of their most vulnerable populations. Moreover, WWF participatory mapping exercises are conducted over short periods, over one to two days per village. While this methodology is potentially less expensive and faster, the aspect of the degree of "participation" and the ability of this approach to grasp the complexity of the community tenure system remains problematic. On the other hand, the methodology proposed by Rainforest Foundation UK and the Natural Resources Network ${ }^{144}$ emphasizes a minimum of 20 days per month in the villages and in participation with the whole community, including the most vulnerable groups, who must be able to control and guide the process themselves. The process is part of continuous support to indigenous and local communities in defining and implementing their advocacy objectives during the mapping process. ${ }^{145} 146$

\section{The initiatives' design and management methodology does not allow communities to feel ownership over them and compromises their sustainability}

All REDD+ projects have been designed around competitive bidding with short deadlines, which does not allow for field consultations. Projects conceived in a non-participatory fashion do not necessarily meet the needs of communities, or be in keeping with their structural and cultural characteristics. Moreover, without community ownership of projects, activities often stop when the source of funding dries up. Interviewed in 2015 by a GTCR-R team in the region of Mbandaka 
(Equator), the villagers and beneficiaries of an agroforestry project explained: "payments are late, so we are no longer planting." ${ }^{147}$ The consequences of this lack of appropriation are apparent in the number of savanna reforestation contracts signed but not enacted by the WWF in Bolobo or in the South Kwamouth project, where only one village-based project is being implemented. The very methodology of results-based payments, provided for in the PIREDDs, does not encourage community ownership and undermines any intrinsic source of motivation, reducing collective action to a Pavlovian reflex: farmers are paid first to make cuttings, and then paid again when they plant, according to a sequence of activities. This payment model precedes and introduces the forms of payments that will be implemented by the ERP. However, it is not always beneficial to communities: rather than finding meaning in the activity itself in order to achieve its purpose and thus appropriate the project, a phenomenon of disempowerment and "wage labor" is likely to take place. This model, central to the REDD+ architecture, is a major concern for its community strategy.

\section{Civil society participation to be encouraged through transparent practices and realistic requirements}

The participation of civil society in the REDD+ process has been repeatedly welcomed in the Democratic Republic of the Congo. ${ }^{148}$ After a collaborative period from 2010 to 2013, the REDD+ Climate Working Group Network has been reconstituted into a renovated GTCR branching out in provinces through provincial and territorial coordination hubs, ${ }^{149}$ supported primarily by Rainforest Foundation Norway and UNDP. Through the GTCR-R, civil society organizations are recognized as key actors in defining and implementing public policies and REDD+-related initiatives, and the network is regarded as such in several programs. However, the participation of stakeholders in the development of ERP has been strongly condemned by civil society. In particular, the GTCR-R emphasized that the design of the ERP took place in a context of "excessive concentration of powers and competences in the hands of the CN-REDD."150 If civil society representatives are invited, their participation is not always full and effective: documents requiring approval are provided the day before or the day of the validation meeting, individual members of the GTCR-R are invited but not the organization itself, meeting are held behind closed doors recommendations are not given follow-up, etc. In addition, the provincial GTCR-R Mai-Ndombe unit lament that, although the network is recognized as a key interlocutor of civil society, it was not consulted in the context of the BioCFplus study conducted prior to the design of PIREDD Mai-Ndombe. ${ }^{151}$ Building consensus, analyses, and strategic positions around such complex issues requires a significant investment in time, as well as a trusting relationship between organizations. The rapid response requirement too often favors superficial work and forced collaborations to the detriment of the quality of the work produced. The limited means also cause conflicts between the organizations, as it hinders the ability to convene a large number of them. 


\section{The importance of independent support from civil society}

To date, the GTCR-R is mainly supported by Rainforest Foundation Norway and UNDP, the REDD+ program lead. The UNDP program has identified Mai-Ndombe province as a "high-intensity REDD+" venue, where local civil society will receive increased technical and financial support. REPALEF receives direct support from the World Bank, which also has a REDD+ program. While such support should be encouraged, the question arises of civil society's independence when supported by the project holders. It could indeed be difficult for civil society to take a stand against its donors in the context of disagreement over the projects they are implementing. In a context where protesters face pressure around the country, civil society's ability to express itself freely is slowed down and special attention must be paid to the establishment of a framework for free expression. It is therefore important that civil society be able to grow the ranks of its technical and financial partners, and benefit from the support of independent actors in the management of REDD+ programs.

\section{A process centralized in Kinshasa with little effect on the ground}

To date, most REDD+ meetings about Mai-Ndombe have taken place in Kinshasa. Consultations on the PPB, for example, took place only in Kinshasa rather than in the province of Mai-Ndombe, where the benefits will be produced and redistributed. It has therefore not been made public to all stakeholders. Only a few organizations in the project areas have been informed, but they denounce the elites in Kinshasa for withholding information on REDD+. There is indeed a real disparity between the participation of Kinshasa's civil society and that of its counterparts in the provinces, and even more so in the territories, at the local level. REPALEF and CERN-Inongo note that very limited information on REDD+ reaches the local level: information meetings and provincial consultations take place in Inongo, or further afield in territorial capitals. But, as the projects point out, forest managers and users are not in urban centers and the information does not reach them. Three major reasons explain this: access and communication difficulties; the differences in skills development opportunities between Kinshasa and the provinces; and the issues surrounding the availability of financial resources. The FIP, whose program provides for the development of infrastructure by restoring previous connective infrastructure (bridges, roads), could help improve infrastructure. This would be a secondary and unplanned impact of this activity, the primary objective of which is to maximize commercial revenue by lowering transportation costs and adding value to products through processing, but which would also facilitate the dissemination of information across the province.

\section{Underutilization of communities in the context of monitoring, reporting and audit (MRV) and IO}

Community involvement in monitoring REDD+ projects is recognized as an asset to ensure their effectiveness beyond carbon accounting. ${ }^{152}$ Participation and empowerment of civil society in the monitoring and evaluation of REDD+ projects have been recommended by the various independent observation missions, led first by the EMN in the forestry sector, then by the OGF and Moabi within the framework of the REDD+. The value of communities' role in monitoring changes in land use and natural resource exploitation was demonstrated, thanks to the NRN, through participatory mapping during the conflict in Mpole and Mpaha. ${ }^{153}$ Communities were able to geolocate the forest concessionaire's illegal logging activities outside the limits of its concession. Along with capacity building and the development of appropriate reporting systems, the national system could, at least in part, rely on community-based monitoring, reporting and audit protocols that would maximize 
the involvement of local communities in monitoring the forest cover and evaluating social impacts. If the modalities of this participation are debatable, they still deserve to be studied, which is not being done in the context of the Mai-Ndombe.

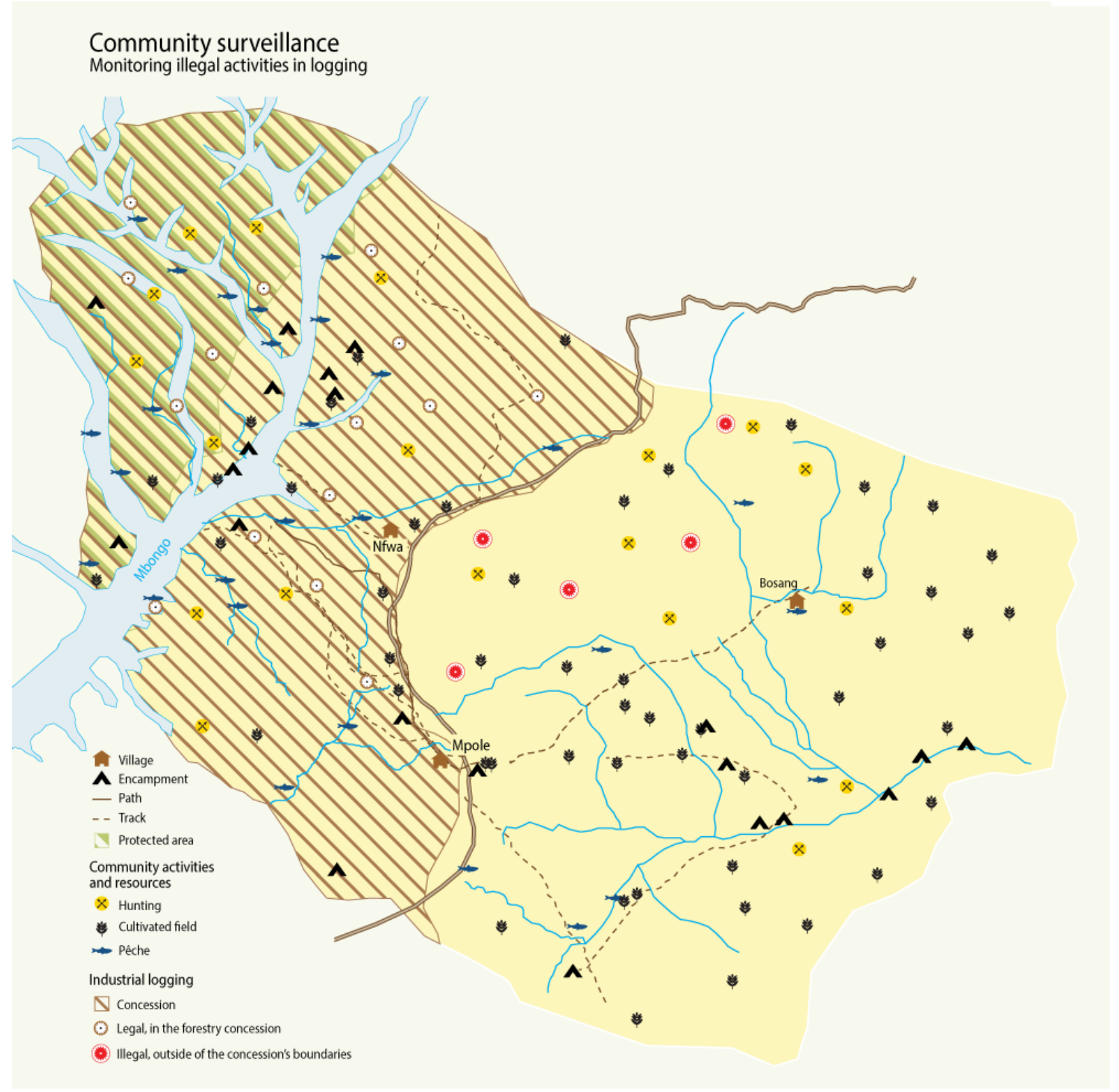




\section{Conclusion and priorities for action - mitigating the risks of implementing REDD+ in Mai-Ndombe}

Originally chosen for the FCPF emission reduction program, Mai-Ndombe now is now the focus of twenty initiatives related to REDD+, foreshadowing the snowball effect provoked by such a program and its impact on the attractiveness of the territory for people, private investors, and civil society.

Given the national and provincial context and the risks pertaining to governance, conflict, and the precariousness of local communities and vulnerable populations such as Indigenous Peoples and women, these initiatives should benefit from better coordination and a coherent programmatic structure in order to limit the aggravation of existing conditions. At a minimum, REDD+ initiatives should ensure that people's livelihoods, including their access to natural resources, respect for their land rights, and even their human rights, are not worsened. International organizations and initiatives, on the other hand, carry the additional obligation to protect and promote these rights as prescribed by the Cancun safeguards. Analyzing the risks and cumulative impacts of the multiplicity of REDD+ initiatives in the province of Mai-Ndombe reveals that the investments made so far do not meet this minimum threshold and do not take into account the risks incurred.

To date, coordination between the various initiatives remains ineffective, lacking sufficient tools and governance structures to mitigate risks. The accumulation of interventions and the anticipated arrival of REDD+ benefits may amplify the land grabbing that is already taking place and provoke new conflicts in the area. In the face of such land predation, the clarification and securing of community rights is only partially addressed, and includes no emphasis on the community forestry approach, no coordinated methodology, and little support to representative structures such as the CLDs, which are too weak to really defend the interests of the communities.

In this context, it is not conceivable to validate an emissions reduction program likely to generate REDD+ revenues. PIREDD's implementation, as well as that of all related projects, should benefit from thorough evaluation and necessary amendments in order to be continued. The land issue, now reduced to inactive land reform in the province, needs to be put back at the heart of REDD+ by defining a clear plan for securing land rights in the province, not just a pilot project.

In order to ensure that community land rights are secure and that REDD+ meets its dual objective of fighting deforestation and poverty, thus benefiting the most vulnerable people, we make the following recommendations:

1. Secure the land rights of local communities, Indigenous Peoples, and women to make local communities the primary beneficiaries of REDD+. Develop a plan for equitable and operational benefits sharing to accelerate community contributions to reducing emissions and sustainable land management through a new certification decree incorporating CFCLs.

It is up to REDD+ technical and financial partners to set up a dedicated fund for approaches focused on the leadership of communities, Indigenous Peoples, and women. Such a fund would be used to study tenure in each REDD+ accounting area in order to understand land issues and dynamics, including migratory dynamics, to clarify customary tenure rights 
through participatory mapping, to clarify the elements of land tenure safeguarding, and finally to establish a clear plan for clarification and securing of tenure rights in Mai-Ndombe over five years. Within this framework, the national and provincial government could then develop, with the agreement of communities and civil society, a participatory support plan for the creation of CFCLs within the framework of REDD+ on the basis of customary tenure as well as a program to strengthen women's leadership and empowerment of project beneficiaries, who should be their main actors. These plans should be based on (i) a new version of the benefit-sharing plan that should be submitted by the government as part of a transparent and inclusive consultation process conducted in relation to land reform with stakeholders directly involved, at the provincial level and in the local language; and (ii) a new certification decree allowing communities to become project leaders via local community forest concessions defined on the basis of participatory mapping.

2. Target the main drivers of current and future deforestation and ensure a better match between legislative tools (e.g. maintaining the moratorium on logging concessions and impose a moratorium on conservation concessions) and incentives provided under REDD+ (e.g., capture of REDD+ revenues by private actors without benefits to communities, while results-based payments are not suitable for community-based projects).

Studies of the drivers of deforestation at the local level should be carried out by the government, taking into account the impact of industrial exploitation and integrating a prospective vision of predictable future drivers, even at the risk of proposing various scenarios. With the same drivers being addressed by various initiatives, the REDD+ provincial level coordinating structure should also help harmonize approaches relating to the same driver of deforestation to ensure a positive impact. Priority should also be given to monitoring the impacts of these initiatives on deforestation, relying on an independent observer and an independent community monitoring system recognized by REDD+ and which would not be dependent on REDD+ project sponsors and donors, neither technically nor financially. As community anchoring of REDD+ initiatives is one of the guarantees of its sustainable impact on deforestation, project promoters should also push for community empowerment, favoring an approach of income generation through entrepreneurship and limiting the use of results-based payments in the case of community projects.

3. Finalize and operationalize key governance tools (recourse and feedback mechanism, benefit-sharing plan, safeguards information system, independent monitoring mechanism) and strengthen the national and provincial REDD+ coordination structure.

The set of REDD+ governance tools should have been finalized during the preparation phase: operational safeguards; recourse and feedback mechanism; benefit-sharing plan; safeguards information system; consultation guide, and so on. Their finalization must be a condition for starting the REDD+ investment phase. The government must also set up, train, and make responsible, with the support of its TFPs, representative national coordination and REDD+ coordination, with clarified roles. Their governance capacities need to be 
strengthened and decentralization must be effective even in the ETDs to enable real monitoring of REDD+ on the ground.

4. Adopt existing conflict management measures for the whole province. Develop a system to identify and mitigate risks, supported by land reform and leading to the recognition of community rights, through the implementation of safeguards and the equitable sharing of benefits.

Any signature of a REDD+ payments agreement must be part and parcel with the implementation of the tools necessary to control the highly contentious and conflict-prone situation in Mai-Ndombe. The government is expected to implement a province-wide recourse and feedback mechanism accessible to all, to finalize the FPIC methodological guide, to ensure wide dissemination of information on REDD+ by integrating communication and awareness raising to the remit of a provincial management body and not to project leaders. Project leaders should establish a conflict management system within each project before they are ratified. As land tenure is one of the main causes of conflict in the province, land reform advocates should have a place in all REDD+ coordination and debate bodies to ensure that initiatives are not the source of additional conflicts. In this context, it is desirable to see the land reform pilot project in other REDD+ programs and in a mixed Bantu-PA zone.

5. Ensure better integration of Indigenous Peoples and women at both the local and provincial level, as they are currently discriminated against in REDD+ decision-making processes, and provide systematic support for women's participation and recognition of Indigenous Peoples' rights

As part of a coherent and effective coordination structure, project promoters can then adapt the governance tools at the level of each project and define specific types of consultation for each project on the basis of the national consultation guide, and define a common participatory mapping methodology for effective participation of all REDD+ stakeholders. At the local level, communities should define their own way of structuring community, to suit their representation and participation in program governance, and put in place community management structures to prevent appropriation by the elites of REDD+ benefits. 


\section{Endnotes}

${ }_{1}^{1}$ Reducing emissions from deforestation and forest degradation, sustainable forest management and conservation, and increasing forest carbon stocks.

2 By the Constitution of the Democratic Republic of the Congo promulgated by decree on February 18, 2006, then by the organic law $n^{\circ} 08 / 016$ of October 7, 2008 on the composition, organization and functioning of the decentralized territorial entities and their relations with the State and the provinces.

${ }^{3}$ Forest Carbon Partnership Fund. 2016a. Document de Programme de Réductions des Émissions (ER-PD) du Mai-Ndombe, Democratic Republic of the Congo, November 2016 version.

https://www.forestcarbonpartnership.org/sites/fcp/files/2016/Nov/20161108\%20Revised\%20ERPD\%20after\%20

CF-14 clean\%20version FR.pdf

4 United Nations Human Rights Council. 2014a, «Compilation établie par le Haut-Commissariat aux droits de l'homme, conformément au paragraphe 15 b) de l'annexe à la résolution 5/1 du Conseil des droits de l'homme et au paragraphe 5 de l'annexe à la résolution 16/21 du Conseil - République démocratique du Congo ».

https://documents-dds-ny.un.org/doc/UNDOC/GEN/G09/123/32/PDF/G0912332.pdf?OpenElement

${ }^{5}$ Transparency International. 2010. «Panorama de la corruption et de la lutte anti-corruption en République démocratique du Congo (DRC) ». https://www.transparency.org/files/content/corruptiongas/257FR-Corruptionand-Anti-Corruption-in-DRC.pdf

${ }^{6}$ World Bank. 2016a. "Worldwide Governance Indicators". Accessed November 3, 2017.

http://info.worldbank.org/governance/wgi/\#home

7 Radio Okapi. 2016. « Mai-Ndombe : le gouverneur Gentiny Ngobila publie son gouvernement ». https://www.radiookapi.net/2016/09/13/actualite/politique/mai-ndombe-le-gouverneur-gentiny-ngobila-publieson-gouvernement

8 Wold Bank 2016a.

${ }^{9}$ Government of the Democratic Republic of the Congo. Constitution de la République Démocratique du Congo. February 18, 2006. Articles 23 and 24. http://www.wipo.int/edocs/lexdocs/laws/fr/cd/cd001fr.pdf

10 Universal Periodic Review. 2014. “Contribution of UNESCO to Compilation of UN information, Democratic Republic of the Congo". http://www.ohchr.org/EN/HRBodies/UPR/Pages/UPRCDUNContributionsS19.aspx

11 United Nations Human Rights Council 2014a

12 Amnesty International. 2016. « Démantèlement de la dissidence, répression de la liberté d'expression sur fond de retard des élections en République Démocratique du Congo ».

https://www.amnesty.org/fr/documents/afr62/4761/2016/fr/

${ }^{13}$ Radio Okapi. 2016. « Mai-Ndombe : L'interdiction des manifestations est impersonnelle, selon le commissaire adjoint », January 28, 2016. https://www.radiookapi.net/2016/01/28/actualite/societe/mai-ndombe-linterdictiondes-manifestations-publiques-est-impersonnelle 
${ }^{14}$ Government of the Democratic Republic of the Congo. Constitution de la République démocratique du Congo. February 18, 2006. Article 58. http://www.wipo.int/edocs/lexdocs/laws/fr/cd/cd001fr.pdf

15 Global Witness. 2017. « Distributeur automatique de billets du régime ». https://www.globalwitness.org/en/campaigns/democratic-republic-congo/distributeur-automatique-de-billetsdu-régime/

${ }^{16}$ Global Witness. 2016. «Congo signs over potential $\$ 880 \mathrm{~m}$ of royalties in Glencore project to offshore company belonging to friend of Congolese President ». Press Release, November 15, 2016, https://www.globalwitness.org/en/press-releases/congo-signs-over-potential-880m-royalties-glencore-projectoffshore-company-belonging-friend-congolese-president/

17 This global and multilateral initiative, which promotes transparency in the extractive sectors by publishing data on companies' financial transactions and remains the best source available on such information, was the victim of misrepresentation by companies in the DRC, and has thus published erroneous reports. See Global Witness. 2017.

18 World Bank. 2013. Enterprise Surveys, Accessed on November 5, 2017 http://www.enterprisesurveys.org/data/exploreeconomies/2013/congo-dem-rep

${ }^{19}$ Transparency International 2010.

20 Trefon, Theodore. 2010. «Forest governance in Congo: Corruption rules? » in U4-Brief September 2010, n5. http://www.u4.no/publications/forest-governance-in-congo-corruption-rules/

${ }^{21}$ PwC (PricewaterhouseCoopers). 2011. «Implementing REDD+ in the Democratic Republic of the Congo: How to Manage the Risk of Corruption ». A report commissioned by NORAD prepared by PwC in collaboration with NORAD and UNDP. http://www.redd-monitor.org/wp-content/uploads/2012/01/NORAD-PwC-ImplementingREDD-in-DRC-Corruption-risks-NORAD-Final-Version-E.pdf

22 Heidelberg Institute for International Conflict Research. 2016. « Conflict Barometer » n²5 https://www.hiik.de/en/konfliktbarometer/pdf/ConflictBarometer 2016.pdf

23 1,5 million selon le document de programme de réduction des émissions du Mai-Ndombe, mais 1,8 million selon la monographie de la province du Bandundu, ministère du Plan, 2005 (données de 2003) - ces données semblent être les dernières données complètes disponibles. Une étude auprès des ménages a été conduite en 2011 par le ministère de l'Agriculture en partenariat avec l'Union européenne et ISCO, mais ces données sont incomplètes et présentent des chiffres inférieurs.

${ }^{24}$ Reyniers C., A. Karsenty and C. Vermeulen. 2016. Les paysans sans terre et REDD+ en DRC : les logiques locales faces aux interventions internationales. in Conjonctures Congolaises 2015. Entre incertitudes politiques et transformation économique, Paris: MRAC / L'Harmattan

https://www.researchgate.net/publication/303873182 Les paysans sans terre et la REDD en RDC les logique s locales face aux interventions internationales

${ }^{25}$ Rights and Resources Initiative. 2016. «Tenure foncière et REDD+ dans le bassin d'approvisionnement » FIP Kinshasa. Information mission for local actors from 24 to 31 August 2016 in Inongo (Province of Mai-Ndombe)"

${ }^{26}$ Rodriguez, Marc. 2015. « Rapport BioCFplus, Proposition pour un Programme REDD+ Intégré au MaiNdombe ». World Bank.

${ }^{27}$ Fonaredd 2016b. 
${ }^{28}$ The price varies from US $\$ 300$ / ha on the Batéké Plateau to less than US $\$ 10$ in remote savannahs, according to the 2015 BioCFplus study

29 Rights and Resources Initiative. 2014. «Etude de référence sur la Tenure en République Démocratique du Congo », unpublished working document.

30 Rights and Resources Initiative 2014a

31 In 2014, several thousand cattle from the Sogenac agricultural concession were slaughtered by peasants in the villages of Mushie and Bolobo following the dispute over the royalty payable to customary landowners.

32 World Rainforest Movement. 2016. Le Projet 'Forêt Tropicale du Bassin du Congo' : les communautés se méfient de la "Révolution de conservation" in Bulletin 221 published February 5, 2016. http://wrm.org.uy/fr/lesarticles-du-bulletin-wrm/section2/le-projet-foret-tropicale-du-bassin-du-congo-les-communautes-se-mefientde-la-revolution-de-conservation/

${ }^{33}$ Greenpeace. 2011. DRC : conflits entre compagnies d'exploitation de bois et communautés forestières, accessed on November 5, 2017 https://www.greenpeace.fr/rdc-conflits-entre-compagnies-dexploitation-dubois-et-communautes-forestieres/

${ }^{34}$ Réseau ressources naturelles. 2015. Que nous apprennent les communautés locales sur la gestion des forêts ? 2005-2015, articipatory mapping experiments in the Democratic Republic of the Congo.

35 Rainforest Foundation UK. 2016. Protected Areas in the Congo Basin: Failing People and Biodiversity? http://www.mappingforrights.org/files/38342-Rainforest-Foundation-Conservation-Study-Web-ready.pdf

${ }^{36}$ Government of the Democratic Republic of the Congo. Constitution de la République démocratique du Congo. February 18, 2006. Articles 204.

${ }^{37}$ Government of the Democratic Republic of the Congo. 2008. Loi n08/12 du 31 juillet 2008 laying down the fundamental principles relating to the free administration of the provinces, article 36.

http://www.leganet.cd/Legislation/Droit\%20Public/Administration.ter/L.13.22.01.2013.htm

38 Rights and Resources Initiative 2014

39 Mpoyi, Augustin. 2013. Amélioration de la gouvernance du secteur foncier en République démocratique du Congo : La mise en œuvre du cadre d'évaluation de la gouvernance foncière (CAGF). Published with the support of the World Bank. http://siteresources.worldbank.org/INTLGA/Resources/DRC Final Report.pdf

${ }^{40}$ Government of the Democratic Republic of the Congo. Constitution de la République démocratique du Congo. February 18, 2006. Articles 34 and 207.

${ }^{41}$ Government of the Democratic Republic of the Congo. Loi n 073-021 du 20 juillet 1973 property regime, land and real estate regime and security regime, as amended and completed by the loi du 18 juillet 1980. http://www.wipo.int/edocs/lexdocs/laws/fr/cd/cd003fr.pdf

42 Mpoyi, Augustin. 2013. Le contexte de la REDD+ en République démocratique du Congo : causes, agents, institutions. Published by CIFOR. https://www.cifor.org/library/4094/le-contexte-de-la-redd-en-republiquedemocratique-du-congo-causes-agents-et-institutions/

${ }^{43}$ Government of the Democratic Republic of the Congo. 2002. Loi N 011/2002 du 29 août 2002 portant code forestier, articles 22, and 111 to 113 http://www.leganet.cd/Legislation/Droit\%20economique/Code\%20Forestier/rdc-loiforets.pdf 
${ }^{44}$ Government of the Democratic Republic of the Congo. Décret N 14/018 du 02 août 2014 laying down the procedures for allocating forest concessions to local communities ; and l'arrêté № 025/CAB/MIN/ECNDD/CJ/00/RBM/2016 du 9 février 2016 on specific provisions for the operation and management of the local community forest concession

45 CAGDFT. 2017. Rapport de l'atelier de sensibilisation des autorités politico-administratives et des OSC sur la foresterie communautaire, Inongo, 24-25 August 2017.

${ }^{46}$ Rights and Resources Initiative 2014

${ }^{47}$ Comité pour l'élimination de la discrimination raciale, Discrimination raciale persistante et généralisée à l'égard des peuples autochtones en République démocratique du Congo. 2006. Demande officielle de mise en œuvre d'une procédure d'action urgente en vue d'éviter des dommages immédiats et irréparables. http://www.forestpeoples.org/sites/fpp/files/publication/2010/08/drccerdjun06fr.pdf

48 Fonaredd. 2016. Document de programme peuples autochtones pygmées. http://www.cafi.org/content/dam/cafi/docs/drc-documents/DRC-Approved\%20Programmes/DRC-Pygmees\%20World\%20Bank/DRC-WorldBank-Gestion\%20Durable\%20Pygmees\%20Prodoc\%20Final Novembre\%202016.pdf

${ }^{49}$ The Oschwe pygmies are Batwa, but they are called "Moone" in this territory. This name is used by PAs in the sector.

${ }^{50}$ REPALEF, 2017. « Projet intégré REDD Mai-Ndombe : Plan en faveur des populations autochtones ». Final version : May 2017. http://www.medd.gouv.cd/v2/images/jdownloads/PIF/P162837_IPP\%20PPA_02\%20Mai\%202017_Final.pdf

${ }^{51}$ Government of the Democratic Republic of the Congo. Constitution de la République démocratique du Congo. February 18, 2006. Article 13

52 Government of the Democratic Republic of the Congo. Constitution de la République démocratique du Congo. February 18, 2006, Article 214

${ }^{53}$ All these texts, signed by the DRC and having a legal value superior to its national laws, recognize the rights of Indigenous Peoples: the International Covenant on Civil and Political Rights, the International Covenant on Economic, Social and Cultural Rights, the International Convention on the Elimination of All Forms of Racial Discrimination, the Convention on Biological Diversity, the Convention on the Elimination of all forms of discrimination against women, as well as the African Charter on Human and Peoples' Rights, and the UN Declaration on the Rights of Indigenous Peoples

54 IWGIA. 2014. «The Indigenous World 2014 ». Copenhagen: IWGIA. https://www.iwgia.org/images/publications//0671 12014eb.pdf

55 This pertains to some villages within the communities of Bolia, Ntomb'e Nzale, Nkaw (Mbidiankana, Imoma, Bokongo) as detailed in the BioCFplus report.

56 REPALEF 2017.

${ }^{57}$ Government of the Democratic Republic of the Congo. 2015. Loi n 15/013 du $1^{\text {er }}$ août 2015 laying down detailed rules for the application of women's rights and parity http://leganet.cd/Legislation/Droit\%20Public/DH/Loi.15.013.01.08.html

$58 \mathrm{Ibid}$ 
59 Rights and Resources Initiative. 2017. Power and potential, a comparative analysis of national laws and regulations concerning women's rights to community forests.

http://rightsandresources.org/en/publication/power-and-potential/

${ }^{60}$ Convention on the Elimination of All Forms of Discrimination against Women (CEDAW). 1979. G.A. Res 34/180. Art. 14(f). www.ohchr.org/Documents/Professionallnterest/cedaw.pdf

61 United Nations Declaration on the Rights of Indigenous Peoples (UNDRIP). 2007. Arts. 21, 22. G.A. Res. 61/295, U.N. Doc. A/ RES/61/295. http://www.un.org/esa/socdev/unp i/documents/DRIPS en.pdf

62 Rights and Resources Initiative 2017.

${ }^{63}$ General Assembly. 2014. Compilation prepared by the Office of the United Nations High Commissioner for Human Rights in accordance with paragraph 15 (b) of the annex to Human Rights Council resolution 5/1 and paragraph 5 of the annex to Council resolution 16/21

${ }^{64}$ Committee on the Elimination of Discrimination against Women. 2013. Concluding observations on the combined sixth and seventh periodic report of the Democratic Republic of the Congo.

http://docstore.ohchr.org/SelfServices/FilesHandler.ashx?enc=6QkG1 d\%2FPPRiCAqhKb7yhsoVqDbaslinb8oXgzp EhivhSIKvzg2xgG7f5gSH\%2BAfHr3v5nPQmjhddT9JT\%2FYb8VszomxpEbJmOxMz0TAQ8u17LsE9|pOpK2Db7rLRbA UmnP76dzyEJep9BxMqeSmJPpVQ\%3D\%3D

${ }^{65}$ CFLEDD. 2017. Rapport de l'atelier de renforcement des capacités des femmes d'Inongo et de Kiri sur les indicateurs de la version finale des standards nationaux environnementaux et sociaux REDD+ pour le programme Mai-Ndombe et rôle des femmes dans le CLD

${ }^{66}$ Reyniers 2015.

${ }^{67}$ Rights and Resources Initiative 2014

${ }^{68}$ Rights and Resources Initiative 2014

${ }^{69}$ Government of the Democratic Republic of the Congo. Constitution de la République Démocratique du Congo. February 18, 2006. Article 207

${ }^{70}$ CFLEDD 2017.

${ }^{71}$ Rodriguez 2015.

72 Government of the Democratic Republic of the Congo, Planning and Monitoring Ministry for the Implementation of the Revolution to Modernity, National Institute of Statistics. 2014. Rapport Global : Enquête 1-2-3 Nationale, Résultats de l'enquête sur l'emploi, le secteur informel, et sur la consommation des ménages, 2012. http://www.ins-rdc.org/sites/default/files/Rapport\%20enquete\%20123.pdf

73 US\$1.90 per day per person, as set by the World Bank in 2015

${ }^{74}$ Government of the Democratic Republic of the Congo, Ministry of Primary, Secondary and Professional Education. Examen national 2015 de l'Education pour tous : République Démocratique du Congo, undertaken with the support of UNESCO. http://unesdoc.unesco.org/images/0023/002317/231719f.pdf

75 Government of the Democratic Republic of the Congo, Bandundu Province, Bandundu Ministry of Agriculture. 2012. Analyse de l'Enquête ménage réalisée en 2011 dans 14 territoires de la Province du Bandundu. With the support of the European Union.

https://www.google.fr/url?sa=t\&rct=j\&q=\&esrc=s\&source=web\&cd=1\&cad=rja\&uact=8\&ved=0ahUKEwjBtKmk6a 
nXAhWRpKQKHRW DHoQFggoMAA\&url=http\%3A\%2F\%2Fwww.fonaredd-rdc.org\%2Fwpcontent\%2Fuploads\%2F2017\%2F07\%2FEnqu\%25C3\%25AAte-socio-\%25C3\%25A9conomique-agriculture-duBandundu.doc\&usg=AOvVaw109vUlyVYOWOUsvYZc2SCF

${ }^{76}$ Reyniers. 2017. « Dynamiques de déforestation et agroforesterie sur le plateau des Batéké », Speech for the « Agriculture, Ruralité et Développement » colloquium, 23 -24 May 2017, Bruxelles

77 REPALEF 2017.

78 Tanwanda. 2014. « Le marché du travail en République démocratique du Congo en 2012 : Principaux résultats de la Phase 1 de l'Enquête 1-2-3 », Paris : Université Paris-Dauphine

79 Rodriguez 2015.

${ }^{80}$ Government of the Democratic Republic of the Congo, Ministry of the Environment and Sustainable Development. Cadre de directives nationales sur le FPIC dans le cadre de la REDD+ en République démocratique du Congo, https://www.forestcarbonpartnership.org/sites/fcp/files/2015/March/Directives\%20nationales\%20sur\%20le\%20 CLIP\%20dans\%20le\%20cadre\%20de\%20la\%20REDD\%20\%20RDC.pdf

81 UN-REDD. 2012. Free and Prior Informed Consent Guidelines. http://www.unredd.net/documents/un-reddpartner-countries-181/templates-forms-and-guidance-89/un-redd-fpic-guidelines-2648/8719-directivesconcernant-le-consentement-prealable-donne-librement-et-en-connaissance-de-cause-onu-redd-8719.html

82 In the case concerning the territory of the Endorois, the African Commission on Human and Peoples' Rights interpreted the right to development from the perspective of the FPIC, taking the view that "for any evolution or development project which would have a major impact on the territory of the Endorois, the State has the responsibility not only to consult the community, but also to obtain their free prior and ulterior consent, in accordance with their customs and traditions"

${ }^{83}$ Forest Peoples Programme. 2016. Land reform and protection of communities' rights - Report of the seminar on information sharing on the land reform process and the protection of communities' rights in the implementation of forest policies and climate initiatives in the DRC.

http://www.forestpeoples.org/sites/fpp/files/publication/2017/05/drc-legality-seminar-english-web 0.pdf

${ }^{84}$ Nelson, Kipalu, Vig. 2012. The Forest Dialogue on FPIC in DRC: Background

paper. http://theforestsdialogue.org/sites/default/files/tfd fpic drc backgroundpaper en1.pdf

85 Government of the Democratic Republic of the Congo. 2015. Plan d'Investissement REDD+ de la République démocratique du Congo. http://www.cafi.org/content/dam/cafi/docs/drcdocuments/DRC 2015 Plan\%20Investissement\%20National\%20REDD\%20RDC\%2024\%20Novembre\%202015.pd $\underline{f}$

${ }^{86}$ Government of the Democratic Republic of the Congo. 2009. Décret N 09/40 du 26 novembre 2009 creating, composing and organizing the implementation structure of the REDD + process, Article 10

${ }^{87}$ Frechette, Alain. 2014. External Evaluation of the United Nations Collaborative Programme on Reducing Emissions from Deforestation and Forest Degradation in Developing Countries (the UN-REDD Programme), UNREDD. http://wedocs.unep.org/handle/20.500.11822/191

88 United Nations Framework Convention on Climate Change (CUNCAC), 2010. Decision adopted by the Conference of the Parties, Decision 1 / CP.16, Annexe 1, Cancún.

http://unfccc.int/resource/docs/2010/cop16/fre/07a01f.pdf 
89 Décret Nº 09/40 du 26 novembre 2009 creating, composing and organizing the implementation structure of the REDD + process, article 10

${ }^{90}$ Fonds de partenariat pour le carbone forestier. 2016a

91 These tools were to be put in place by Moabi, who positioned itself as an independent observer, and MINDEV, a consulting firm. CN-REDD, after proposing the terms of reference, never followed-up, and these projects were therefore suspended.

92 These tools, designed with the financial support of EFI and IIASA, had been mentioned in ERP D as part of the REDD + monitoring, reporting and verification (MRV) system in the DRC, through the establishment of a control mechanism based on mandated independent observation (IOM).

${ }^{93}$ Rainforest Foundation UK. 2017. A critical analysis of the safeguards framework of the Mai-Ndombe PIREDD project. http://www.redd-monitor.org/wp-content/uploads/2017/08/PIREDD-safeguards-

analysis 31.7 .17 final.pdf

${ }^{94}$ To date, the VCS certification, Verified Carbon Standard, remain the certification chosen as part of the WWC Conservation Concession.

95 Reference UNDP 2010 in the Transparency REDD+ report

${ }^{96}$ LICOCO. 2015. Note on ERP D.

${ }_{97}$ DIM, Direct Implementation Modality

${ }^{98}$ Fonaredd 2016a.

${ }^{99}$ Reyniers 2017.

100 Interview with Abbott Jean Paul Lokutu, coordinator of the Mai-Ndombe provincial GTCR-R

101 Moabi. 2015. « Mission test des standards nationaux REDD+ de la DRC » Accessed on November 5, 2017 http://rdc.moabi.org/mission-test-de-standard-nationaux-redd-de-la-rdc/fr/\#8/2.038/18.517\&layers=moabi_redd_projects,moabi_fip_zones

102 GTCR. 2015. Information gathering - Inongo Provincial Workshop for the Call to develop the Global Strategy of REDD + Restructuring Climate Working Group Platform (GTCR), with the inclusion of women, youth and indigenous Pygmy peoples.

103 Brown. 2017. Implementing REDD+ in a Conflict-Affected Country: A Case Study of the Democratic Republic of the Congo, in Environments, 2017 http://www.mdpi.com/2076-3298/4/3/61

104 CUNCAC 2010

105 FCPF 2016 p. 54

106 FCPF 2016 p.106

107 During the conservation prioritization workshop for Central Africa, organized by WWF in 2000, CARPE defined eight natural landscapes of carbon-rich forests and biologically sensitive resources in Central Africa, considered as priority targets of conservation

${ }_{108}$ CARPE. 2008. Rapport de l'atelier de formation sur la planification et l'aménagement des paysages. http://carpe.umd.edu/Documents/2008/RAPPORT_USFS_CARPE_Kinshasa_nov2008 vers_finale.pdf 
109 Interview with anonymous source from FONAREDD.

110 Fonaredd. 2016. Feuille de route pour l'analyse et l'atténuation des risques encourus ou induits par les programmes du FONAREDD, December 2016. http://www.cafi.org/content/dam/cafi/docs/drcdocuments/RDC\%20MATRICE\%20DE\%20GESTION\%20DES\%20RISQUES\%20-\%20ATELIER\%2078\%20DECEMBRE\%202016.pdf

111 REPALEF 2017.

112 CFLEDD. 2017. Rapport de l'atelier de renforcement des capacités des femmes d'Inongo et de Kiri sur les indicateurs de la version finale des standards nationaux environnementaux et sociaux REDD+ pour le programme Mai-Ndombe et rôle des femmes dans le CLD, p.20

113 Interview with Abbott Jean Paul Lokutu, coordinator of the Mai-Ndombe provincial GTCR-R

114 Government of the Democratic Republic of the Congo, Ministry of the Environment, Nature Conservation and Tourism, 2012. Etude qualitative sur les causes de la déforestation et de la dégradation des forêts en République Démocratique du Congo. http://www.forestpeoples.org/sites/fpp/files/publication/2013/05/etudequalitative-causes-dd-menee-par-le-gtcr-faofinalaout2012.pdf

115 FCPF 2016. P.40

116 GTCR-R. 2015. Note de position et recommandations de la société civile environnementale de la République démocratique du Congo par rapport au plan d'investissement REDD+.

117 Forest Peoples Programme. 2016. Securing Forest Peoples' Rights and Tackling Deforestation in the Democratic Republic of the Congo - Deforestation drivers, local impacts and rights-based solutions. http://www.forestpeoples.org/sites/fpp/files/publication/2016/05/fppdrcreportinternet-2.pdf

118 Environmental Investigation Agency. 2016. Preliminary comments by the Environmental Investigation Agency on the Democratic Republic of the Congo's Emission Reduction Program Document for the World Bank Forest Carbon Partnership Facility, final draft dated January 2016

${ }^{119}$ Fonaredd. 2016. Document de Programme Société Civile, p.24

http://www.cafi.org/content/dam/cafi/docs/drc-documents/DRC-Approved\%20Programmes/DRCCicil\%20Society-UNDP/DRC-UNDP-Societe\%20Civile-Prodoc\%20Final Dec\%202016.pdf

120 Seyllier. 2016. L'« économie virtuelle » des projets REDD+ : la certification privée des projets REDD+ garantitelle leur intégrité environnementale ? International Forestry Review 18(2):231-246.

http://agritrop.cirad.fr/580695/

121 Forest Peoples Programme 2016

122 Resource Extraction Monitoring. 2013. Observation indépendante de la mise en application de la loi forestière et de la gouvernance (OI-FLEG) en République démocratique du Congo - Rapport Final. http://www.observation-rdc.info/documents/Rapport annuel OIFLEG RDC REM 2013.pdf

123 International Crisis Group. 2006. Sortir du piège du conflit : Promouvoir la bonne gouvernance au Congo, Rapport n¹14. https://www.crisisgroup.org/fr/africa/central-africa/democratic-republic-congo/escapingconflict-trap-promoting-good-governance-congo

124 Rainforest Foundation UK. 2017. Logging in Congo's rainforests: a "carbon bomb" about to be primed by the Government of Norway? http://www.rainforestfoundationuk.org/media.ashx/drc-carbon-bomb-briefing2017.pdf 
125 CUNCAC 2010

${ }^{126}$ CUNCAC 2010

127 United Nations, 2008. UN Declaration on the Rights of Indigenous Peoples.

http://www.un.org/esa/socdev/unpfii/documents/DRIPS_en.pdf

${ }^{128}$ Fonaredd 2016c

129 CFLEDD 2017

130 Government of the Democratic Republic of the Congo. Note circulaire $n^{\circ} 006 / C A B / M I N / E C N$ -

DD/05/00/RBM/2016

131 Rights and Resources Initiative 2017

132 Forest Carbon Partnership Facility. 2016. Cadre méthodologique du Fond de partenariat pour le carbone forestier - Final révisé, Criteria 30

https://www.forestcarbonpartnership.org/sites/fcp/files/2014/MArch/March/FCPF\%20Cadre\%20Méthodologiqu e\%20final\%2012\%202013.pdf

133 Greenpeace. 2014. Exploitation industrielle du bois en République démocratique du Congo : populations sous tensions, Accessed on November 5, 2017. https://www.greenpeace.fr/exploitation-industrielle-du-bois-enrepublique-democratique-du-congo-populations-sous-tensions/

134 Government of the Democratic Republic of the Congo, Ministry of the Environment, Nature, Conservation and Sustainable Development, National REDD Coordination. 2012. Rapport de l'Atelier sur l'Evaluation des Risques de Corruption dans le Precessus REDD+ en DRC, http://www.forestpeoples.org/sites/fpp/files/publication/2013/05/rapport-final-atelier-analyse-des-risques-decorruption-redd-en-rdc.pdf

135 Fairhead, Leach, Scoones. 2012. Green Grabbing: a new appropriation of nature? In The Journal of Peasant Studies, Volume 39. http://www.tandfonline.com/doi/abs/10.1080/03066150.2012.671770

136 Government of the Democratic Republic of the Congo, Ministry of the Environment, Nature Conservation and Tourism. 2012. Arrêté ministériel n004/CAB/MIN/ECN-T/012 du 15 février 2012 laying down the procedure for the approval of REDD + projects. https://www.documents.clientearth.org/library/download-info/arreteministeriel-004cabminecn-t012-du-15-fevrier-2012-fixant-la-procedure-dhomologation-des-projets-redd/

137 Rodriguez 2015, p.69

138 Fonaredd 2016c

139 Central Africa Forest Initiative. 2015. Lettre d'Intention, p.3. http://www.cafi.org/content/dam/cafi/docs/drcdocuments/DRC 2016 LOI V7\%20FINALE\%20-\%2018\%20Avril\%202016\%20-\%20FR-\%20avec\%20logos.pdf

140 FCPF 2015 p.30

141 Reyniers 2017

142 UN-REDD, FCPF. 2012. Directives concernant l'engagement des parties prenantes à la préparation de REDD+, axées sur la participation des peuples autochtones et autres collectivités tributaires des forêts.

https://www.google.fr/url?sa=t\&rct=j\&q=\&esrc=s\&source=web\&cd=1\&ved=0ahUKEwiTs\&vlgqrXAhXFxqQKHSpd Dh8QFggqMAA\&url=http\%3A\%2F\%2Fwww.unredd.net\%2Fdocuments\%2Fglobal-programme191\%2Fstakeholder-engagement-295\%2Fkey-documents-1095\%2F8209-lignes-directrices-du-fcpf-et-le- 
programme-onu-redd-concernant-l-engagement-des-parties-prenantes-a-la-preparation-de-la-redd-

8209\%2Ffile.html\&usg=AOVVaw0py5gMW2gVsO55Wh-fmD6Q

143 CUNCAC 2010

${ }^{144}$ Rainforest Foundation UK. 2015. La Méthodologie de Mapping for Rights : une nouvelle approche de la cartographie participative dans le bassin du Congo. http://www.mappingforrights.org/files/2909565-

FRENCH LOWRES.pdf

${ }^{145}$ CADEM, NRN. 2016. Situation et perspectives des Batwa dans les secteurs de Bolia et d'Inongo, territoire d'Inongo, province de Mai-Ndombe, DRC, Analyse participative.

${ }^{146}$ CADEM, RRN. 2016. Situation et perspectives des Batwa dans les secteurs de Bolia et d'Inongo, territoire d'Inongo, province de Mai-Ndombe, RDC, Analyse participative.

147 Observations made by the author during the GTCR-R / UNDP field mission in June 2015

148 UNDP, Regnskogfondet, Gauthier. 2016. La société civile rassemblée pour la REDD+ en République démocratique du Congo - Analyse et leçons apprises du processus d'engagement et de structuration de la société civile et des Peuples autochtones dans le processus REDD.

149 UNDP. 2015. Accompanying civil society through the REDD+ process.

http://www.unredd.net/documents/redd-papers-and-publications-90/un-redd-publications-1191/un-reddpublications-by-technical-topic/stakeholder-engagement/15249-accompanying-civil-society-through-the-reddprocess-in-the-democratic-republic-of-congo.html

150 GTCR. 2012. Memorandum de la société civile environnementale congolaise sur le processus REDD en DRC.

151 Interview with Abbott Jean Paul Lokutu, coordinator of the Mai-Ndombe provincial GTCR-R

152 Bong, Felker, Maryudi. 2016. How Are Local People Driving and Affected by Forest Cover Change? Opportunities for Local Participation in REDD+ Measurement, Reporting and Verification. In PLoS ONE 11 http://journals.plos.org/plosone/article?id=10.1371/journal.pone.0145330

153 Natural Resources Network. 2015. Que nous apprennent les communautés locales sur la gestion des forêts ? 2005-2015 - Expériences de cartographie participative en République démocratique du Congo. 